Portland State University

PDXScholar

\title{
"Had sh'er haute gamme, high technology": An Application of the MLF and 4-M Models to French- Arabic Codeswitching in Algerian Hip Hop
}

Samuel Nickilaus McLain-Jespersen

Portland State University

Follow this and additional works at: https://pdxscholar.library.pdx.edu/open_access_etds

Part of the Discourse and Text Linguistics Commons, and the Music Commons Let us know how access to this document benefits you.

\section{Recommended Citation}

McLain-Jespersen, Samuel Nickilaus, "'Had sh'er haute gamme, high technology": An Application of the MLF and 4-M Models to French-Arabic Codeswitching in Algerian Hip Hop" (2014). Dissertations and Theses. Paper 1631.

https://doi.org/10.15760/etd.1630

This Thesis is brought to you for free and open access. It has been accepted for inclusion in Dissertations and Theses by an authorized administrator of PDXScholar. Please contact us if we can make this document more accessible: pdxscholar@pdx.edu. 
"Had Sh'er Haute Gamme, High Technology":

An Application of the MLF and 4-M Models to French-Arabic Codeswitching in Algerian Hip Hop

by

Samuel Nickilaus McLain-Jespersen

A thesis submitted in partial fulfillment of the requirements for the degree of

Masters of Arts

in

Teaching English To Speakers of Other Languages

Thesis Committee:

Keith Walters, Chair

Lynn Santelmann

Kimberley Brown

Portland State University

2014 
McLain-Jespersen i

\begin{abstract}
The historical nature of language contact between French and Arabic in Algeria has created a sociolinguistic situation in which French is permeated throughout Algerian society. The prevalence and use of spoken French in Algeria by native speakers of Spoken Algerian Arabic has been a topic of interest to researchers of codeswitching since the 1970s. Studies have been conducted on codeswitching in Algerian media such as television, radio, and music.

The hip hop scene has been active in Algeria since the 1980s. Algerian hip hop lyrics contain a multitude of switches into French. This study explores the structural makeup of the codeswitching between French and Spoken Algerian Arabic in Algerian hip hop. These are pattern that have gone heretofore unstudied.
\end{abstract}

The purpose of this study was to utilize Myers-Scotton's MLF and 4-M models in order to analyze the codeswitching between Spoken Algerian Arabic and French found in the lyrics to the hip hop album Kobay by popular Algerian hip hop artist Lotfi Double Kanon. This study had two goals: the first was to document the structural patterns of the codeswitching found in the data. The second goal was to test Myers-Scotton's models and determine whether the patterns found in the data could be predicted by the MLF and 4-M models.

In order to accomplish these goals, the lyrics to the album were transcribed, translated, coded and analyzed at the level of the complementizer phrase. The principles of the MLF and 4-M models were used as central tool for analysis.

This study demonstrates that the codeswitching found in the lyrics to Kobay 


\section{McLain-Jespersen ii}

follow the principles of the MLF and 4-M models to a great extent. However, three examples of problematic data are presented. This is followed by a discussion on the social and structural implications of these findings. 


\section{McLain-Jespersen iii}

\section{ACKNOWLEDGMENTS}

First and foremost, many thanks to my adviser, mentor, motivational speaker, editor, counselor and white-wizard Keith Walters for working his magic and getting me through this trying process, sending me to Morocco (twice), and not giving up on me. It was quite a ride.

Secondly, I would have never started or completed this project without the invaluable assistance of my cultural informants Nawel, Bouchra, Driss and Rima. I also owe my gratitude to my friends Ashure and Latifa for their advice. I hope to work with each one of you in the future, and I wish each of you every success you have helped me to achieve. Shukran bezzaf!

Additionally, I want to thank everyone who read my paper, particularly Dr. Brown and Dr. Santelmann. Your advice, suggestions, feedback and encouragement were indispensable to the success of this study.

Finally, I'd like to thank my parents, my sister, and my lovely girlfriend Sarah for seeing me through this phase of my life without disowning me. 


\section{TABLE OF CONTENTS}

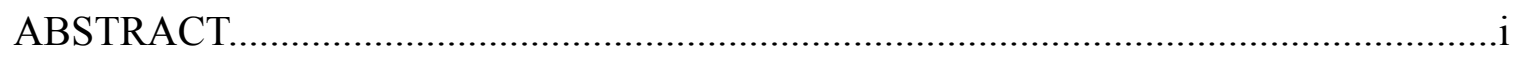

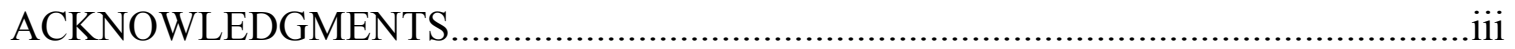

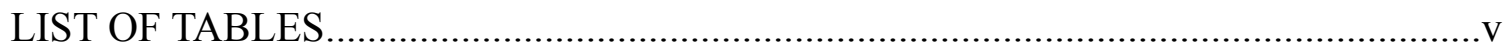

LIST OF FIGURES........................................................................................ vii

LIST OF ABBREVIATIONS....................................................................................

CHAPTER ONE: INTRODUCTION .....................................................................

CHAPTER TWO: REVIEW OF THE LITERATURE....................................................

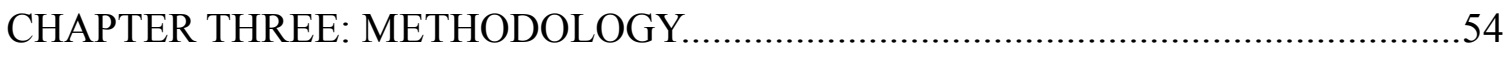

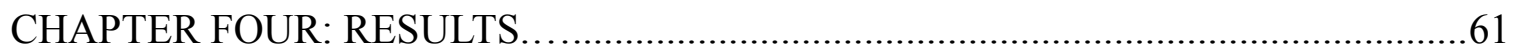

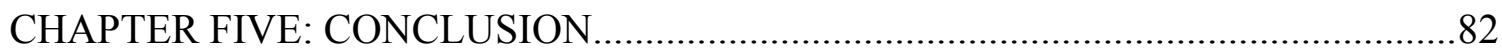

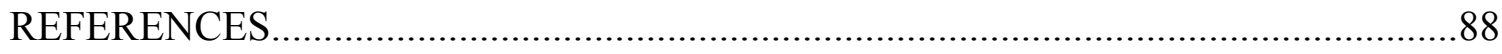

APPENDIX: CPS CONTAINING CODESWITCHING ...........................................93 


\section{LIST OF TABLES}

Table 1: Distribution of Vowels in Spoken Algerian Arabic............................................13

Table 1a: Distribution of Consonantal Phonemes in Spoken Algerian Arabic...................14

Table 2: Behavior of the Definite Article when Followed by Sun and Moon Letters.......16

Table 3: Behavior between Prepositions and the Definite Article......................................16

Table 4: Examples of Common SAA Words from the Trilateral Root /k/, /t/, /b/.............17

Table 5: Conjugation Chart for /ktəb/ ("he wrote")........................................................19

Table 6: Conjugation Chart for /ma $/ \bar{a} /$ ("he went")........................................................19

Table 7: Imperative Voice Formation for /ktəb/ ("he wrote")............................................20

Table 8: Gender Marking on Animate and Inanimate Nouns..........................................21

Table 9: Sound Plural Markers on Masculine and Feminine Nouns.................................22

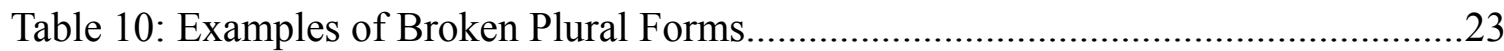

Table 11: Independent and Suffixed Pronouns...............................................................24

Table 12: Suffixed Pronouns Attached to Verbs, Nouns and Prepositions..........................25

Table 13: SAA Noun Phrases demonstrating the Genitive Construction Using the

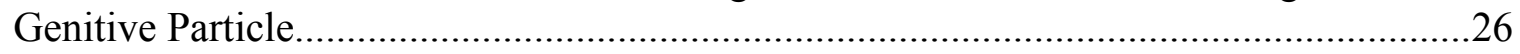

Table 14: SAA Noun Phrases Demonstrating the Genitive Construction Using the

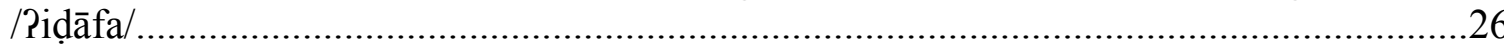

Table 15: SAA Noun Phrases Demonstrating Noun-Adjective Agreement........................27

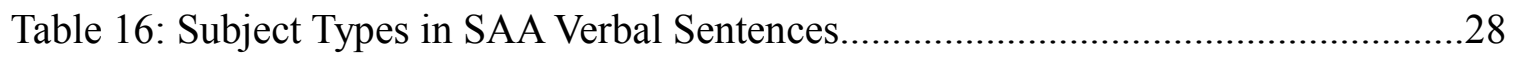

Table 17: Negation of Verbal Sentences Using the Negative Particles..............................29

Table 18: Equational Sentences in Present, Negative Present, Past, and Negative Past

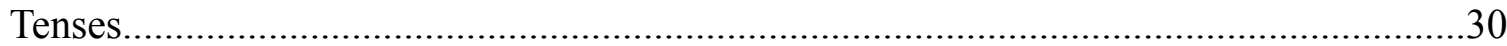


Table 19: Existential Sentences in Imperfect, Negative Imperfect, Perfect, and Negative

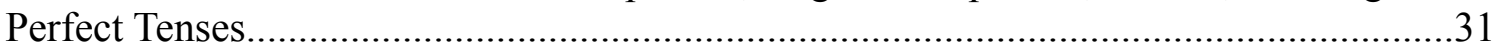

Table 20: Replacement of Consonants in French Words Used in SAA..............................34

Table 21: Replacement of Vowels in French Words Used in SAA....................................35

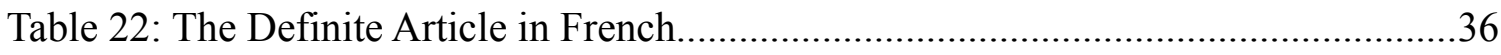

Table 23: French Gender Marking on Nouns Codeswitched into SAA...............................37

Table 24: French Definite Plural Nouns Codeswitched into SAA......................................38

Table 25: SAA Participles Created from French Verb Stems..............................................39

Table 26: Conjugation Chart for /forse/ ("he forced").......................................................40

Table 27: Morpheme Types in the 4-M Model...............................................................51

Table 28: Counts for Utterances, CPs, and Stranded Phrases ........................................59 


\section{LIST OF FIGURES}

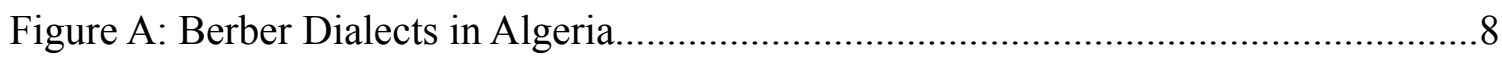

Figure B. Major Spoken Arabic Dialects in Algeria .....................................................

Figure C: Sun and Moon Letters on Definite Articles Modifying French Nouns..............37

Figure 1: An Example of Codeswitching Between Cps...................................................46

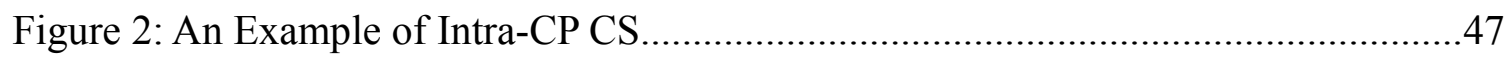

Figure 3: An Example of a French EL Island Code-switched into an SAA CP..................48

Figure 4: An Example of a French Lexeme Code-switched into an SAA CP.....................49

Figure 5: An Example of CS with Each Morpheme Type from the 4-M Model................52

Figure 6: An Example of the First Step of Data Transcription and Translation.................56

Figure 7: An Example of the Second Step of Data Transcription and Translation.............56

Figure 8: An Example of the Third Step of Data Transcription and Translation................57

Figure 9: An Example of the Final Step of Data Transcription and Translation................57

Figure 10: An SAA CP Containing a French Noun ..........................................................62

Figure 11: An SAA CP Containing a French Noun Modified by an SAA Definite

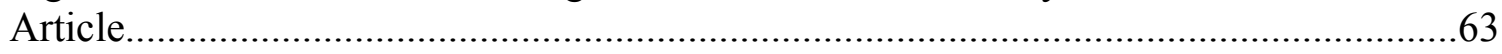

Figure 12: An SAA CP Containing a French Noun Modified by an Ambiguous Definite

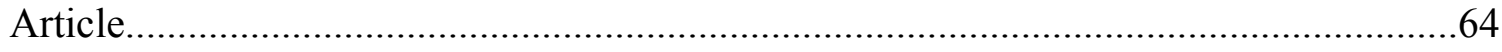

Figure 13: An SAA CP Containing a French Adjective....................................................65

Figure 14: An SAA Sentence Containing a French Adverb..............................................65

Figure 15: An SAA Sentence Containing an Extra-sentential French Adverb...................66

Figure 16: An SAA CP Containing a French Verb Stem in the SAA Perfect Tense..........67

Figure 17: An SAA CP Containing a French Verb Stem in the SAA Imperfect Tense......68 
Figure 18: An SAA CP Containing a French Verb Stem in the SAA Imperative Voice....70

Figure 19: An SAA CP Containing a French Verb Stem made into an SAA Participle.....70

Figure 20: An SAA CP Containing a French EL Island Consisting of a Definite Article

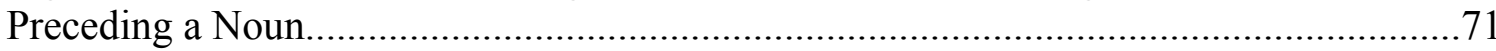

Figure 21: An SAA CP Containing Adjective-Noun French and English EL Island

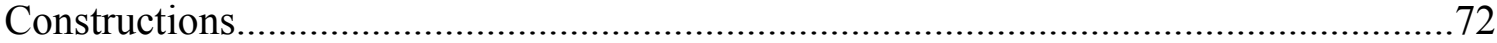

Figure 22: An SAA CP Containing a French EL Island Consisting of Two Nouns Joined

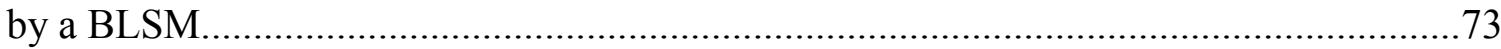

Figure 23: An SAA CP Containing a French EL Island Consisting of a Prepositional Phrase.

Figure 24: An SAA CP Containing a French Noun Modified by both French and SAA

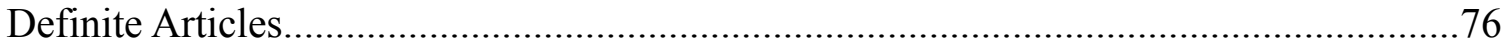

Figure 25: An SAA CP Containing an SAA Verb Modified by the French Adverb

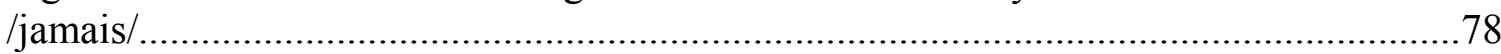

Figure 26: An SAA CP Containing an SAA Verb Modified by the SAA [९əmr]

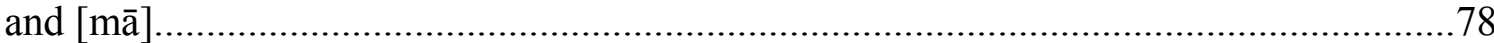

Figure 27: Example 1 of an SAA Sentence Containing an Ambiguously Conjugated French Verb Stem. .80

Figure 28: Example 2 of an SAA Sentence Containing an Ambiguously Conjugated French Verb Stem 


\title{
LIST OF ABBREVIATIONS
}

\author{
1 - first person \\ 2 - second person \\ 3 - third person \\ 4-M - Four Morpheme \\ BLSM - bridge late system morpheme \\ $\mathrm{CP}$ - complementizer phrase \\ CS - codeswitching \\ DEF - definite \\ EL - embedded language \\ ESM - early system morpheme \\ F, FEM - feminine \\ FUT - future \\ GEN - genitive \\ INDEF - indefinite \\ INF - infinitive \\ IMP - imperative \\ IMPF - imperfect \\ M, MASC - masculine \\ $\mathrm{ML}$ - matrix language \\ MLF - Matrix Language Frame \\ NEG - negative
}


NP - noun phrase

OBJ - object

OLSM - outside late system morpheme

PARTIC - participle

PERF - perfect

PL - plural

POS - possessive

PRES - present

$\mathrm{PRO}$ - pronoun

PROG - progressive

SAA - Spoken Algerian Arabic

$\mathrm{SG}$ - singular

VP - verb phrase 
McLain-Jespersen 1

\section{CHAPTER ONE: INTRODUCTION}

This study examines the use of the French language in the Algerian hip hop album Kobay (an Arabization of the French word 'cobaye' 'guinea pig') by the contemporary Algerian rap group Double Kanon. The purpose of this study is to better understand the nature of codeswitching between Spoken Algerian Arabic and French, two languages that have a complex history of contact in Algeria.

I discovered Double Kanon in a Spoken Algerian Arabic class here at Portland State University. The instructor at the time, Nawel Krarzia, used some of the group's lyrics as part of one of her lessons. From there my interest in Algerian hip hop expanded, and I discovered more and more artists rapping lyrics that were fast, passionate, and, most interesting to me, filled with French words. I wanted to know if there were any patterns or structure to these lyrics and whether or not they reflected natural language use. This is how I began my study on the nature of codeswitching in this context.

I was eventually led to Myers-Scotton's Matrix Language Frame (MLF) and Four Morpheme (4-M) models as a framework for analyzing these lyrics. While the MLF model is the most used model in the study of codeswitching today, it is not without its major limits. For example, as the model stands now, parts of it rely on circular logic, as discussed on page 50 below. This challenge presented a stumbling block for me more than once. Eventually, I joined in the ranks of the researchers who work around this flaw and continued in my analysis. 
My decision to analyze data in Spoken Algerian Arabic and French was not a difficult one. I have been formally studying Arabic for a decade and have been studying North African Arabic since I first went to Morocco as part of the CLS Scholarship in summer of 2009. Since that time, I studied Algerian Arabic for a year in the class mentioned above and spent a year living in Morocco as part of a Fulbright scholarship. I feel comfortable analyzing North African spoken Arabic with the assistance of native speakers. In order to better prepare myself to analyze the French, I attended a year of French here at PSU.

One of the biggest challenges was applying the complicated history of contact between the French and the Algerians to the language of the study. Which French words were codeswitched, and which had already been assimilated sometime in the past 150 years? This question was helped along by the time I spent in Morocco as well as the conversations I have had with my cultural informants.

Another challenge was the nature of rap lyrics. Rap lyrics are supposed to be complex and difficult to decode, even to native speakers of the language in which the lyrics are written. Word play, creative rhyme schemes, and nonstandard linguistic inventions are abundant in most rap lyrics. Needless to say, the most time consuming part of this project for me was transcribing rap lyrics spoken in two languages I do not speak natively and then analyzing them morpheme by morpheme. 
I relied on the expertise of four cultural informants over the span of two years to complete the task of transcribing and translating the album. Bouchra and Nawel were my main two cultural informants; they are both from from Eastern Algeria. Bouchra was a medical student from Annaba and is approximately 25 years old. She was an active member of the Arabic section of the website www.allthelyrics.com, an online forum devoted to translating songs into English. Nawel was approximately 30 and a graduate student in Tebessa. She was a Foreign Language Teaching Assistant at Portland State University in 2009-2010 with the international Fulbright program and taught Spoken Algerian Arabic here.

Additionally, I received translation and comprehension assistance from Driss Hanafi, a 28-year-old English teacher from Errachidia, Morocco, and Rima Daoud, a speaker of Tunisian Spoken Arabic and French. Without the invaluable help of these four individuals, I simply would not have been able to complete this study as I designed it. I'd like to acknowledge each of their contributions and my gratitude for them.

\section{$\underline{\text { Research questions }}$}

This proposal will seek to answer the following research questions:

1. What are the structural patterns of SAA-French codeswitching found in the lyrics of Kobay by Double Kanon?

2. To what extent do the MLF and 4-M models account for these patterns? 
Chapter Two provides a review of the literature regarding the languages of Algeria and codeswitching. Chapter Three follows to detail the methodology I used to collect, codify, and analyze the data for this study. Next, Chapter Four provides a summary of the results, including acceptable patterns of CS as well as structural configurations that require further explanation as they present challenges to the models used for this study. Finally, Chapter Five discusses the implications of the study and suggests areas of further research. 


\section{CHAPTER TWO: REVIEW OF THE LITERATURE}

In this chapter, I discuss the linguistic situation of Algeria, including the social place of Tamazight, Arabic, and French. Next, I give a relatively detailed treatment of the grammars of SAA and French relevant to this study's codeswitching; this information on the respective grammar is necessary for understanding how the data fits with the models used in the analysis of this study. Additionally, I offer a short history of hip hop in Algeria. Finally, I detail the literature pertaining to codeswitching, which will include the MLF and 4-M models.

\section{The Languages of Algeria}

The three main languages in Algeria are Tamazight, Arabic, and French. Tamazight is the language of the native inhabitants of North Africa and is spoken by tens of millions of people. While understanding Tamazight's place in Algerian society is essential to understanding the sociolinguistic situation there, it is not especially relevant to this study and will be discussed only briefly.

Arabic is the predominant language in Algeria today. Because of its diglossic nature (Ferguson, 1959), there are two types of Arabic in Algeria: Modern Standard Arabic (MSA) and Spoken Algerian Arabic. MSA is related to Classical Arabic (CA), the language of the Qur'an. This variety of Arabic has a long literary and liturgical history and has gone through centuries of codification, standardization, and lexical expansion. It has a history of adopting foreign words due to Islam's quick spread through the region. MSA today represents these collective efforts as well as continuing modern efforts of standardization. MSA is not anyone's native language; it must be learned in 
school. Modern Standard Arabic today is spoken across the Arabic-speaking world in religious sermons, news broadcasts, and university lectures. While there are some instances of MSA being used in Algerian rap (Davies \& Bentahila, 2006), the data for my study do not contain any markedly MSA structures. Therefore, the grammar of MSA will not be discussed.

Spoken Algerian Arabic (SAA) is the language of the majority in Algeria. SAA is a variety of spoken Arabic that is part of the Arabic dialect continuum of North Africa, which contains varieties of spoken Arabic that are markedly divergent from the more influential spoken varieties such as Egyptian, Khaliji (Gulf Arabic), and Levantine. It differs greatly from MSA, so much so that many linguists consider SAA, as well as all other spoken varieties of Arabic, to be distinct languages. By many of its native speakers, SAA is considered to be a deficient dialect of MSA because it is not written and has never undergone standardization (Ennaji, 1991). While there have been analyses of SAA's grammar by Algerians (Keddad, 1986; Bouhadiba, 1988; Souag, 2006) and Western linguists (Bergman, 2005) alike and a working grammar has been constructed, it is important to remember that SAA is highly variable along geographic and socio-economic lines. The SAA of this study is distinct to the large city of Annaba, on the eastern edge of Algeria, and could be described as 'educated'; therefore, it would differ significantly from the SAA spoken by a relatively uneducated rural inhabitant in western Algeria. Using the sources available to me, I will detail the phonology, morphology and basic syntax of SAA in order to inform the discussion of the data in the light of the MLF and 4-M models. 
Finally, I will discuss the history and social place of the French language in Algeria. Due to a long history with French colonialism, many Algerians speak French today. It is still the preferred language of science, administration, and business. Codeswitching between SAA and French is an everyday occurrence in a variety of situations, including rap lyrics. No matter the context, the use of French currently holds prestige in Algeria.

Below I discuss the history of Tamazight, SAA, and French in Algeria. I follow this with a treatment of the relevant grammatical sections of SAA and French as needed to comprehend this study's codeswitching data.

\section{Tamazight}

The indigenous population of Algeria, and all of North Africa, has been traditionally referred to as "Berbers" by Western and Arab scholars. The Berbers themselves tend to use the term Amazigh, meaning "free man," as their identifying marker. The Amazigh speak a group of Afro-Asiatic dialects spanning across North Africa from Morocco to western Egypt as well as throughout the Sahara desert and into the Sahel. Although each one of these dialects has its own name, as a group they are increasingly referred to as Tamazight, which is the feminine form of the word Amazigh.

Large Tamazight-speaking populations have continuously inhabited Algeria since prehistory and have persisted through several waves of Arabization, starting with the first Muslim conquest of North Africa in the 7th century CE. Tamazight-speakers have been in close contact with Arabic-speakers since, and thus the language contains many Arabic 
loans, especially stock phrases and religious vocabulary. Though Tamazight is related to Arabic only very distantly, both are based on a root-and-pattern morphology, which no doubt eased the assimilation of Arabic forms. Varieties of North African spoken Arabic have likewise borrowed many words of Tamazight origin.

Today there are approximately ten major dialects of Tamazight left in North Africa, and at least six of them exist in Algeria, as is shown in Figure 1 below. Taqbaylit of the Kabylie region and Chaoui of the Ares region are the two major Algerian varieties with populations of approximately five million and three million respectively. Overall, it is estimated that 20-25 percent of Algeria's population speak some form of Tamazight to some degree.

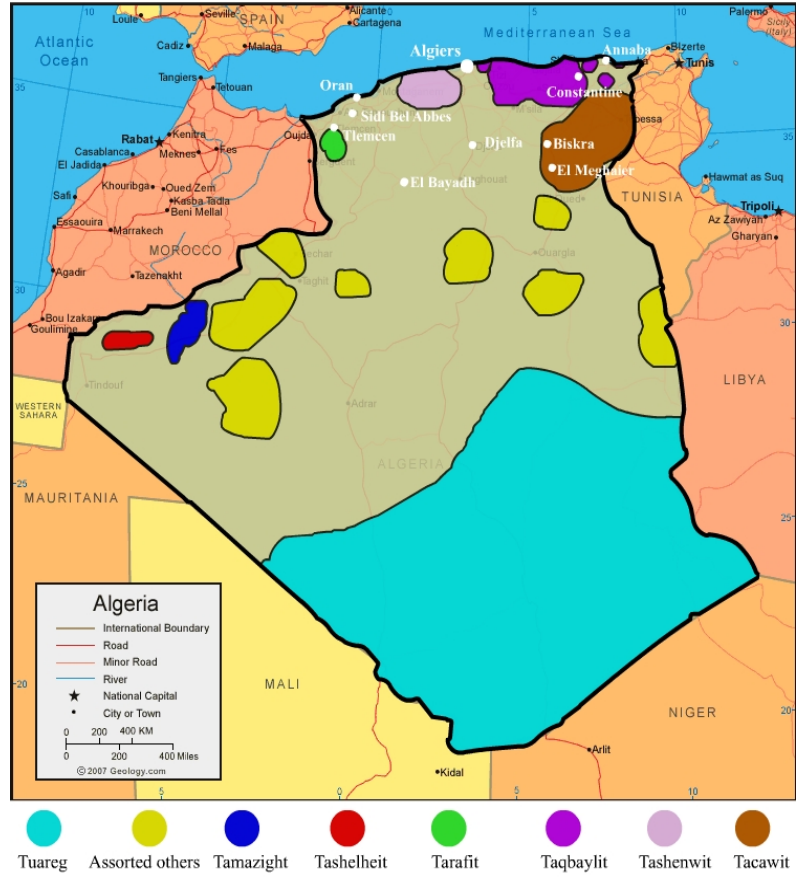

Figure A: Berber Dialects in Algeria. Adapted by the author from http://geology.com/world/algeria-map.gif using information found on http://en.wikipedia.org/wiki/Berber_languages 


\section{Spoken Algerian Arabic}

Spoken Algerian Arabic (SAA) generally refers to Arabic spoken within the borders of Algeria. Algeria has within its borders six major varieties of spoken North African Arabic that fall within the North African Arabic dialect continuum, as shown in Figure 2 below. While Figure 2 above identifies the Arabic spoken in the town of Annaba (from which the artist who provided the data for this study hails) as Tunisian Arabic, it is thought of as Algerian Arabic because it is within the borders of Algeria. What is thought of as Tunisian Arabic is very similar to if not indistinguishable from eastern Algerian Arabic spoken in towns such as Annaba and Constantine. Likewise, the eastern most Moroccan Arabic variety is much like the western Algerian Arabic spoken in towns such as Tlemcen and Oran.

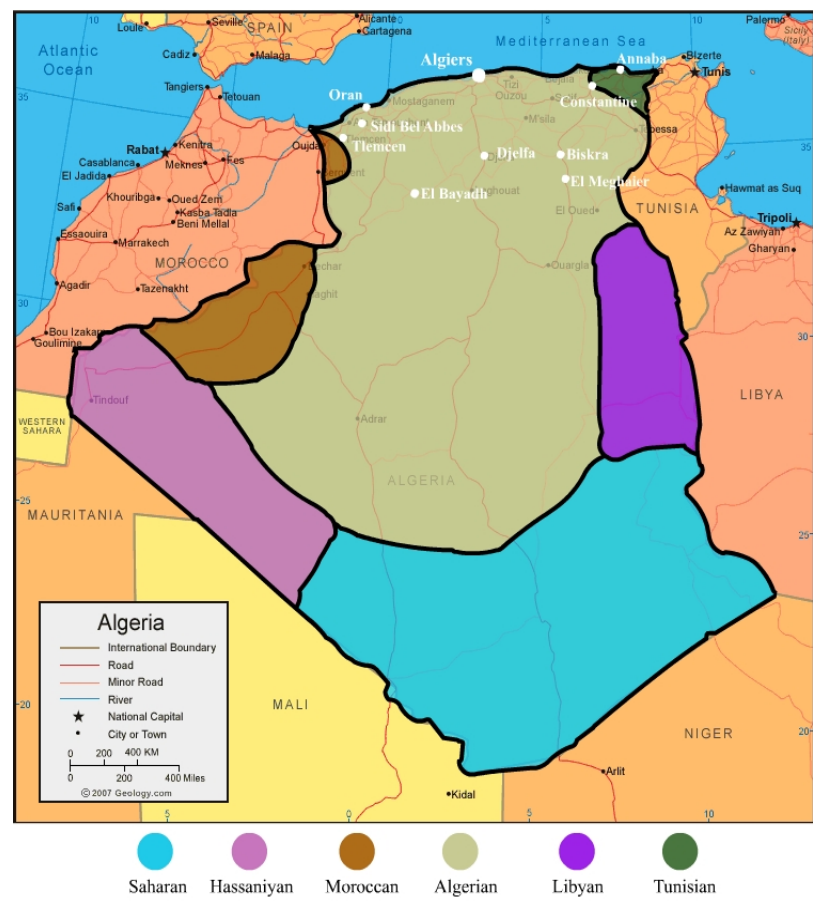

Figure B. Major Spoken Arabic Dialects in Algeria

Adapted by the author from http://geology.com/world/algeria-map.gif using information found on http://en.wikipedia.org/wiki/North_African_Arabic 
SAA is the native language of the majority of Algerians and the second language of those whose first language is a variety of Tamazight. Since it is related to MSA, it is useful to examine how SAA and MSA differ. SAA, like every spoken national variety of Arabic that exists today, differs notably from MSA syntactically, morphologically, phonologically, and lexically. Syntactically it lacks many of the more complex grammatical features of MSA. For example, unlike the VSO word order of MSA, SAA most often exhibits an SVO word order. In addition, SAA does not include a casemarking system like MSA, though speakers will sometimes use case-marked forms in order to elevate their speech. Phonetic distinctions in MSA are often collapsed in SAA (as well as in spoken varieties of MSA). The lexicon available in SAA includes a multitude of words for everyday objects and concepts that MSA lacks, but generally not the academic, scientific, and otherwise learned vocabulary of MSA. Thus, speakers often use such vocabulary from MSA or French when speaking about such topics.

North African varieties of Arabic are highly divergent from the Eastern dialects as well, so much so that a speaker from Algeria and a speaker from Oman speaking their own dialects would have great difficulty understanding one another, especially when discussing the concerns of everyday life. This phenomenon is partially due to SAA's lexicon which is marked by an abundance of words of Tamazight origins, especially in stock phrases and the vocabulary of produce, animals, and other natural features. In order to communicate effectively with one another in these sorts of contact situations, speakers would need to rely on MSA, forms from other dialects, intermediate forms that are neither dialect nor MSA, and European languages. 
McLain-Jespersen 11

French

French has been used in Algeria since as early as the $16^{\text {th }}$ century. The coastal region of Algeria was under Ottoman rule from 1525 until France's conquest of Algeria in 1830, at which point French became the language of the colonizer. In 1848, Algeria became a département of France, that is, it was officially incorporated into the country. Control over Algeria was hard fought, however, as the mountainous Kabylie region east of Algiers, home to one of the groups of Berber speakers, was not fully captured until 1871. It was then that the French finalized the borders of Algeria that still exist today. Complete French dominion of Algeria was never actually achieved as the Algerian Sahara was never under French control in any real sense.

Prior to the French invasion, a considerable number of Algerians were literate in Arabic. Traditional Islamic education taught male students to read and write Classical Arabic from an early age as part of the memorization of the Qur'an. French speakers came and settled in waves, bringing French culture, language, and institutions. French became the official language of administration, business, and education. Islamic education was actively suppressed, and the Arabic language was pushed to the margins of society. Not only was Arabic far removed from the domain of the new French speakers, but the French educational system that was established began to transform a once Arabicspeaking population into Francophones. Finally, in 1936, Arabic was declared a foreign language in Algeria.

By the time Algeria won its independence in 1962, there were over one million French settlers and their descendants in Algeria. After independence, Algeria had a 
population that was largely illiterate in MSA, and many non-Berbers who did not speak SAA fluently; indeed, many Arabs were more comfortable speaking French than they were speaking any variety of Arabic. Despite the policy of Arabization starting in the late 1960 's, French remained an unofficial language and was taught as a second language from elementary school on. In Algeria today, French is associated with modernity and urbanity and is widespread throughout Algerian institutions, media, and culture (Kadga \& Abdul Latif, 2009). It is especially highly valued among Kabyle speakers and the urban elite. The French that most Algerians use today has undergone phonological and morphological shifts that mark it as uniquely Algerian, though there are some who speak a variety of French that is virtually indistinguishable from the French spoken in major urban centers in France.

\section{The Grammar of SAA}

I will now detail the structural elements of SAA that are relevant to the codeswitching data of this study. First, I will describe the phonology of SAA, which will inform the following discussion of the process of assimilation when the definite article /əl/ cliticizes with the noun following it, a rule that applies to codeswitched French nouns as well. I will also cover the behavior of prepositions followed by a cliticized definite article.

Next, I will detail relevant morphological patterns of SAA: verb conjugation, gender and number marking, and suffixed pronouns. These morphemes are essential to the understanding of how the 4-M Model applies to the codeswitching data for this study. 
Finally, I will discuss the genitive construction, noun-adjective agreement, adverb placement, and sentence types, all of which are syntactic patterns of SAA that have relevance to how French words and structures are integrated in codeswitched utterances.

\section{Phonology}

Below is a treatment of the vowels and consonants of SAA followed by a discussion of the behavior of word-initial sounds on nouns with a definite article.

\section{Vowels}

SAA distinguishes between long and short vowels. The short vowels are /a/, /i/, and $/ \mathrm{u} /$. These short vowels tend to neutralize to [ə] depending on factors such as the speed and/or formality of the conversation. The long vowels, $/ \overline{\mathrm{a}} /, / \overline{\mathbf{l}} /$, and $/ \overline{\mathrm{u}} /$, directly correspond with the short vowels. Table 1 below summarizes this information.

\begin{tabular}{|c|c|c|}
\hline \multicolumn{3}{|l|}{$\begin{array}{l}\text { Table 1 } \\
\text { Distribution of Vowels in Spoken Algerian Arabic }\end{array}$} \\
\hline Short vowels & Long vowels & Vowel type \\
\hline $\mathrm{a}$ & $\overline{\mathrm{a}}$ & Open front unrounded \\
& & vowel \\
\hline $\mathrm{i}$ & $\overline{\mathrm{l}}$ & Close front unrounded \\
& & vowel \\
\hline $\mathrm{u}$ & $\overline{\mathrm{u}}$ & Close back rounded vowel \\
\hline$\partial$ & $\varnothing$ & Mid-central vowel \\
\hline
\end{tabular}




\section{Consonants}

Table 1a below shows the consonantal sounds used in SAA adapted from Bergman (2005).

Table 1a

Distribution of Consonantal Phonemes in Spoken Algerian Arabic

\begin{tabular}{|c|c|c|c|c|c|c|c|c|c|}
\hline & 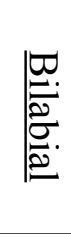 & 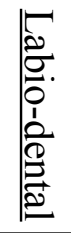 & 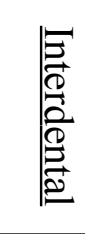 & 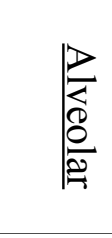 & 莞 & $\frac{\widehat{\overbrace{}}}{\stackrel{\overbrace{}}{\approx}}$ & 吕 & 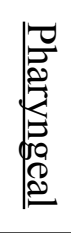 & $\frac{\Omega}{\stackrel{D}{D}}$ \\
\hline Voiceless stop & & & & $\mathbf{t}, \mathbf{t}$ & & $\mathrm{k}$ & $\mathrm{q}$ & & $?$ \\
\hline Voiced stop & $\mathrm{b}$ & & & $\mathbf{d}, \underline{\mathbf{d}}$ & & $\mathrm{g}$ & & & \\
\hline Voiceless fricative & & $\mathrm{f}$ & $\boldsymbol{\theta}$ & $\mathbf{s}, \mathbf{s}$ & $\int$ & $\mathrm{x}$ & & $\hbar$ & $\mathrm{h}$ \\
\hline Voiced fricative & & & ठ & $\mathbf{z}$ & 3 & $\mathrm{y}$ & & $\varsigma$ & \\
\hline$\underline{\text { Nasal }}$ & $\mathrm{m}$ & & & $\mathbf{n}$ & & & & & \\
\hline Lateral & & & & $1, !$ & & & & & \\
\hline$\underline{\text { Trill }}$ & & & & $\mathbf{r}$ & & & & & \\
\hline Semi-vowel & $\mathrm{w}$ & & & & $\mathrm{j}$ & & & & \\
\hline
\end{tabular}

There is some variation with respect to the use of the emphatic alveolar and interdental consonants /ț/, /̣̣/, and /ṣ/. Depending on sociolinguistic factors, these consonants are sometimes collapsed into their non-emphatic counterparts /t/, /d/, and /s/ respectively. However, some speakers alternate between the use of both emphatics and non-emphatics, even in the same utterance (Bergman, 2005). The emphatic alveolar lateral consonant /!̣/ is used exclusively in the word /ḷāah/ 'God,' as is generally the case in varieties of spoken Arabic. 
'Sun letters' and 'Moon letters'

Arabic linguistics has long identified two categories of Arabic letters: 'sun letters' and 'moon letters.' Sun letters are those that represent the coronal consonants (i.e. the dental, alveolar and palatal natural classes) of Arabic. The Arabic word for 'sun,' / Jəms/, starts with the palatal voiceless fricative sound, which is a sun letter. In Table 1 above, sun letters are in boldface. Moon letters represent every other category of sound. The Arabic word for 'moon,' /qamar/, starts with a uvular voiceless stop, which is a moon letter, hence, the logic of the labels.

Sun and moon letters affect the pronunciation of the definite article, which precedes the noun and is cliticized to it. The definite article /əl/ has two allophones, [əl] and [1]., the distribution of which is not relevant to this discussion. When the article precedes a sun letter, it is realized at the phonetic equivalent of that sun letter, and those two sounds together form a doubled consonantal sound. When the definite article precedes a moon letter, it does not assimilate; that is, the definite article remains [əl] or [1]. Table 2 below shows sun letter-assimilation with / fəms/ ('sun') and /dars/ ('lesson'), moon letter non-assimilation with /qamar/ ('moon') and /iqtișād/ ('economy'), and elision of the initial [ə] of the definite article with /iqtișād/ ('economy') and /dars/ ('lesson'). 
Table 2

Behavior of the Definite Article when Followed by Sun and Moon Letters

\begin{tabular}{|c|c|c|}
\hline$\underline{\text { Definite article }+ \text { noun }}$ & $\underline{\text { Definite noun }}$ & $\underline{\text { Meaning }}$ \\
\hline /əl/ + /qamar/ DEF + moon & [əl-qamar] DEF-moon & the moon \\
\hline /əl/+ /iqtiṣād/ DEF + economy & [1-iqtișād]DEF-economy & the economy \\
\hline$/ \curvearrowright 1 /+/ \int ə m s / D E F+$ sun & {$\left[\partial \int-\int \partial \mathrm{ms}\right] \mathrm{DEF}-\mathrm{sun}$} & the sun \\
\hline /əl/+ /dars/ DEF + lesson & [d-dars] DEF-lesson & the lesson \\
\hline
\end{tabular}

Prepositions and definite articles

When the preposition /fì/ ('in'), /bi/ ('by,' 'in'), /li/ ('to'), /cla/ ('about,' 'to') or /min/ ('from') is followed by the definite article, cliticization occurs between them; thus, a phrase like /fĩ d-dār/ ('in the house') is realized as the single phonological word, in this case as [fi-d-dār]. In the cases of $/ \mathrm{min} /$ and $/ \mathrm{Sla} /$, all but the initial consonant of the preposition is eliminated (along with the pause between the preposition and the definite article.) These transformations happen with both sun and moon letters as is shown in Table 3 below.

Table 3

Behavior between Prepositions and the Definite Article

\begin{tabular}{|c|c|c|}
\hline$\frac{\text { Preposition }+ \text { definite article }+}{\underline{\text { noun }}}$ & Phonetic realization & Meaning \\
\hline $\begin{array}{l}/ \mathrm{min} /+/ \mathrm{l} \mathrm{l} / \text { + /qamar } / \\
\text { from }+\mathrm{DEF}+\text { moon }\end{array}$ & $\begin{array}{l}\text { [me-1-qamar] } \\
\text { from-DEF-moon }\end{array}$ & from the moon \\
\hline $\begin{array}{c}/ \text { / la/ } / \text { / /ol } / \text { + /iqtișād } / \\
\text { about }+ \text { DEF + economy }\end{array}$ & $\begin{array}{l}\text { [Sa-1-iqtișād] } \\
\text { about-DEF-economy }\end{array}$ & about the economy \\
\hline $\begin{array}{l}/ \mathrm{li} /+/ \partial \mathrm{l} /+/ \int \partial \mathrm{ms} / \\
\text { to }+\mathrm{DEF}+\operatorname{sun}\end{array}$ & $\begin{array}{l}{\left[1 \mathrm{i}-\int-\int \partial \mathrm{ms}\right]} \\
\text { to-DEF-sun }\end{array}$ & to the sun \\
\hline $\begin{array}{l}/ \mathrm{bi} /+/ \mathrm{ol} /+/ \text { dars } / \\
\text { by }+\mathrm{DEF}+\text { lesson }\end{array}$ & $\begin{array}{c}\text { [bi-d-dars }] \\
\text { by-DEF-lesson }\end{array}$ & by the lesson \\
\hline $\begin{array}{c}/ \mathrm{f} \mathbf{1} /+/ \partial \mathrm{l} / \text { + /dār } / \\
\text { in + DEF + house }\end{array}$ & $\begin{array}{c}\text { [fi-d-dār] } \\
\text { in-DEF-house }\end{array}$ & in the house \\
\hline
\end{tabular}




\section{Morphology}

Below are the relevant morphological aspects of SAA that appear in the codeswitching data of this study. First, I will treat Arabic's method of word formation because it is essential in understanding how verbs are conjugated. Next, I will show the conjugation patterns of the most common verb forms as well as 'finally weak' verb forms, the latter of which inform the discussion of French verbs conjugated into SAA held in a later section. Finally, I will detail the rest of the SAA morphemes that appear on French words codeswitched into SAA: gender markers, number markers, and suffixed pronouns.

\section{The trilateral root system}

Arabic nouns, adjectives, verbs, and some prepositions are based on a trilateral root system. Each word is built from systematic variation around three letters, most often consonants, in a specific order. The trio of letters usually carries a general meaning, and all the words derived from it will be associated with that meaning. For example, the idea of writing is maintained through all the words based on the root of $/ \mathrm{k} /, \mathrm{t} /, / \mathrm{b} /$. Some examples of these words are shown in Table 4 below.

Table 4

Examples of Common SAA Words from the Trilateral Root / $/ \mathrm{k} / \mathrm{t} / \mathrm{/} / \mathrm{b} /$

\begin{tabular}{|c|c|}
\hline$\underline{\text { SAA word }}$ & Meaning \\
\hline ktəo & he wrote \\
\hline kitāb & book \\
\hline kutūb & books \\
\hline maktūb & written (past participle, m., sg.) \\
\hline maktab & office / library \\
\hline maktaba & school \\
\hline
\end{tabular}




\section{Verb conjugation}

Arabic verbs are divided into two basic categories: 'sound verbs' and 'non-sound verbs.' A sound verb is one based on a root that does not contain $/ \overline{\mathrm{a}} /, / \overline{\mathrm{i}} /, / \overline{\mathrm{u}} /$, or $/ \mathrm{2} /$ as one or more of its radicals. In contrast, a non-sound verb is a verb based on a root that does contain one or more of these sounds. These sounds are considered 'weak' because they take different forms in systematic ways in various contexts (e.g., / $\bar{a} /$ is realized as $[\overline{1}])$ whereas other sounds, all consonants, remain constant.

Verb conjugations of sound and non-sound verbs differ systematically. Below I treat SAA verb conjugation and give examples of conjugation of both verb types. For the purposes of this study, the only non-sound verbs I discuss will be the ones which have a 'weak' final radical (i.e. 'finally weak' verbs). This distinction is important because French verbs codeswitched into SAA are conjugated as if they were finally weak SAA verbs. I will show an example of French verb conjugation into SAA in a later section.

Verbs in SAA are morphologically marked for person and tense. Strictly speaking, there is no infinitive; however, the perfect tense 3 rd person masculine singular is the unmarked form. For example, the verb "to write" in its base form in SAA is /ktəb/ which translates as "he/it wrote." Verbs are conjugated for person and tense (perfect/imperfect) via the addition of affixes to the unmarked form. One of the distinctive features of SAA and North African Arabic verb conjugation is a symmetry of prefixes between the singular and plural: the prefixes /nə-/, /tə-/, and /jə-/ are used for the first, second, and third person. The plural is then distinguished by the suffix /- $\overline{\mathrm{u}} /$. While the addition of this suffix triggers a shift in primary stress, such phonological detail is not 
relevant to this discussion.

Table 5 below gives the conjugation for the SAA sound verb /ktəb/ ("he wrote"), which contains the radicals $/ \mathrm{k} /, / \mathrm{t} /$, and $/ \mathrm{b} /$.

Table 5

Conjugation Chart for /ktab/ ("he wrote")

\begin{tabular}{|c|c|c|c|c|}
\hline & \multicolumn{2}{|c|}{$\underline{\text { Perfect (past tense) }}$} & \multicolumn{2}{|c|}{ Imperfect (present tense) } \\
\hline & $\underline{\text { Singular }}$ & $\underline{\text { Plural }}$ & $\underline{\text { Singular }}$ & $\underline{\text { Plural }}$ \\
\hline$\underline{1 \text { st Person }}$ & \multirow[t]{2}{*}{ ktəb-t } & ktəb-nā & nə-ktəb & nə-ktb- $\bar{u}$ \\
\hline 2nd Person (m) & & \multirow[t]{2}{*}{ ktəb-tū } & tə-ktəb & \multirow[t]{2}{*}{ tə-ktb-ū } \\
\hline 2nd Person (f) & ktəb-ti & & tə-ktb-i & \\
\hline$\underline{\text { 3rd Person }(\mathrm{m})}$ & ktəb & \multirow[t]{2}{*}{ kətb-ū } & jə-ktəb & \multirow[t]{2}{*}{ jə-ktb-ū } \\
\hline$\underline{\text { 3rd Person (f) }}$ & kətb-ət & & tə-ktəb & \\
\hline
\end{tabular}

Table 6 below gives the conjugation for the SAA finally weak verb /ma $\sqrt[a]{a} /$ ("he went"), which is composed of the radicals $/ \mathrm{m} /, / \mathrm{J} /$, and $/ \overline{\mathrm{a}} /$.

Table 6

Conjugation Chart for /mafä/ ("he went")

\begin{tabular}{|c|c|c|c|c|}
\hline & \multicolumn{2}{|c|}{$\underline{\text { Perfect (past tense) }}$} & \multicolumn{2}{|c|}{ Imperfect (present tense) } \\
\hline & $\underline{\text { Singular }}$ & $\underline{\text { Plural }}$ & Singular & $\underline{\text { Plural }}$ \\
\hline$\underline{1 \text { st Person }}$ & \multirow[t]{2}{*}{$\mathbf{m} \int \overline{\mathbf{I}}-\mathrm{t}$} & m $\int \overline{1}-n a ̄$ & nə-m/ī & nə-m/ī-w \\
\hline 2nd Person (m) & & \multirow[t]{2}{*}{$\mathbf{m} \int \overline{\mathbf{i}}-\mathrm{tu}$} & \multirow[t]{2}{*}{ tə-m/î } & \multirow[t]{2}{*}{ 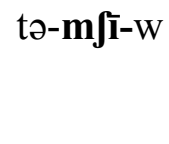 } \\
\hline$\underline{\text { 2nd Person (f) }}$ & $\mathbf{m} \int \overline{\mathbf{i}}-\mathrm{t} \overline{\mathbf{1}}$ & & & \\
\hline$\underline{\text { 3rd Person (m) }}$ & $\mathbf{m} \int \overline{\mathbf{a}}$ & \multirow[t]{2}{*}{$\mathbf{m} \int \overline{\mathbf{a}}-\mathrm{w}$} & jə-m/i & \multirow[t]{2}{*}{ 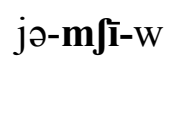 } \\
\hline$\underline{\text { 3rd Person (f) }}$ & $m \int \bar{a}-t$ & & 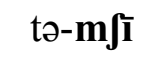 & \\
\hline
\end{tabular}

Note that in Table 5 above, the conjugated form of the sound verb $/ \mathrm{ktəb} /$ retained each of its radicals $(/ \mathrm{k} /, / \mathrm{t} /, / \mathrm{b} /)$ and the short vowels distributed among the consonants were altered systematically. In contrast, Table 6 above shows that the final radical $/ \bar{a} /$ of 
the weak verb /ma $\sqrt{\mathrm{a}} /$ is realized as either $[\overline{1}]$ or $[\overline{\mathrm{a}}]$, depending on the context.

\section{The imperative voice}

The imperative voice in SAA has three forms: the second person masculine singular, the second person feminine singular, and the second person plural. The imperative voice is formed by replacing the prefixes from the second person imperfect forms with null markers. Table 7 below shows the contrast between the forms of the imperative voice and the second person imperfect tense for the SAA sound verb $/ \mathrm{ktab} /$ ("he wrote")

\begin{tabular}{|c|c|c|c|}
\hline \multicolumn{4}{|c|}{\begin{tabular}{|l} 
Table 7 \\
Imperative Voice Formation for /ktab/ ("he wrote")
\end{tabular}} \\
\hline & Masculine singular & $\underline{\text { Feminine singular }}$ & Plural \\
\hline$\frac{\text { Second person }}{\text { imperfect }}$ & $\begin{array}{c}\text { tə-ktəb } \\
\text { 2-write.IMPERF }\end{array}$ & $\begin{array}{c}\text { tə-ktb-i } \\
\text { 2-write.IMPERF- } \\
\text { FEM }\end{array}$ & $\begin{array}{c}\text { tə-ktb- } \bar{u} \\
\text { 2-write.IMPERF-PL }\end{array}$ \\
\hline Imperative voice & $\begin{array}{l}\text { Q-ktəb } \\
\text { IMP-write }\end{array}$ & $\begin{array}{c}Q \text {-ktb-i } \\
\text { IMP-write-FEM }\end{array}$ & $\begin{array}{l}Q-k t b-\bar{u} \\
\text { IMP-write-PL }\end{array}$ \\
\hline
\end{tabular}

\section{Gender marking}

Like all varieties of Arabic, SAA is characterized by grammatical gender. Nouns are either masculine or feminine (there is no neuter gender) with masculine as the unmarked form. Generally, animate nouns have both masculine and feminine forms, while inanimate nouns will generally be only one or the other. With a few exceptions, a feminine noun is one that end in /a/, which is expressly used as a feminine marker on nouns. Note the exceptions in Table 8 below: the words /dār/ 'house' and /uxt/ 'sister' do not end in $/ \mathrm{a} /$, yet they are grammatically feminine. 


\section{Table 8}

Gender Marking on Animate and Inanimate Nouns

\begin{tabular}{|c|c|c|}
\hline Type of noun & $\underline{\text { Masculine and generic }}$ & $\underline{\text { Feminine }}$ \\
\hline \multirow[t]{3}{*}{ Animate nouns } & $\begin{array}{l}\text { ustād } \\
\text { professor }\end{array}$ & $\begin{array}{c}\text { ustād-a } \\
\text { professor-FEM }\end{array}$ \\
\hline & $\begin{array}{l}\text { muhandis } \\
\text { engineer }\end{array}$ & $\begin{array}{c}\text { muhandis-a } \\
\text { engineer-FEM }\end{array}$ \\
\hline & $\theta$ & $\begin{array}{c}\text { uxt } \\
\text { sister }\end{array}$ \\
\hline \multirow[t]{3}{*}{ Inanimate nouns } & 8 & $\begin{array}{l}\text { madīna } \\
\text { city }\end{array}$ \\
\hline & $\begin{array}{l}\text { dīn } \\
\text { religion }\end{array}$ & $\theta$ \\
\hline & $\theta$ & $\begin{array}{c}\text { dār } \\
\text { house }\end{array}$ \\
\hline
\end{tabular}

\section{Number marking}

Nouns in SAA are marked for both dual and plural through the use of suffixes (the dual is rarely used except for a small variety of things that come in pairs, such as body parts like 'eyes', 'ears', 'feet' and a few other cases.) Suffixed plural forms are called 'sound plurals.' SAA also contains 'broken plurals,' so names because the vowels used in the plural form differ from those in the single. Broken plurals are formed by altering the vowels around the radicals of the noun (cf. /kitāb/ 'book' and /kutūb/ 'books' in Table 4 above.) 


\section{Sound plurals}

Masculine sound plurals are marked by the suffix /in/. Masculine sound plurals are used primarily for animate nouns referring to professions, such as 'engineers' (/muhandis/ $\rightarrow$ /muhandis-īn/) and 'travelers' (/msāfir/ $\rightarrow$ /msāfir-īn/), and to nationalities, such as 'Algerians' (/dzīrī/ $\rightarrow$ /dzīrij-īn/) or 'Egyptians' (/mașrīi $/ \rightarrow$ /maṣrījin/). These plurals are used to refer to both masculine groups and mixed-gender groups.

Feminine sound plurals are marked by the suffix /āt/. The feminine sound plural can be used for both animate and inanimate feminine nouns. With few exceptions, /āt/ will replace the /a/ feminine marker on feminine nouns.

Table 9 below shows the masculine and feminine sound plurals on animate and inanimate nouns.

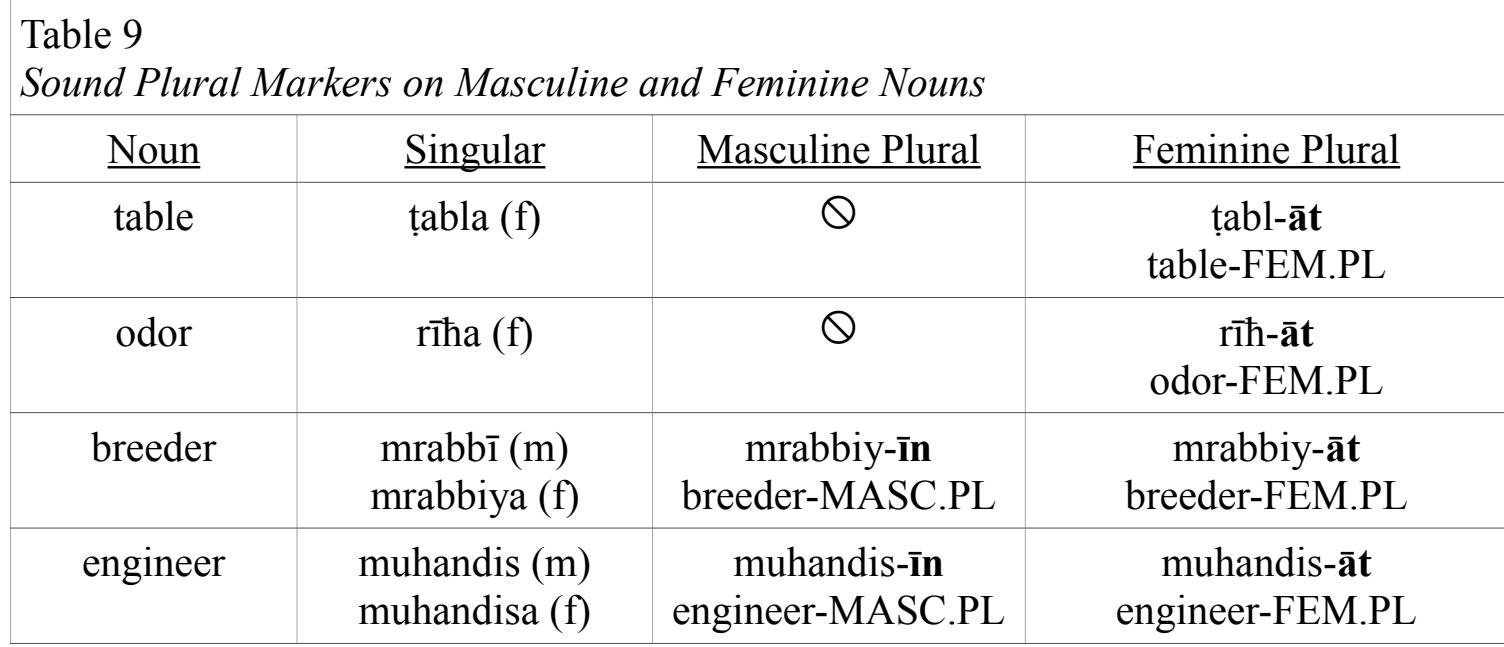

\section{Broken plurals}

Broken plurals are formed by the alteration of the sounds surrounding the radicals of a noun. While there are over a dozen different patterns of broken plural, they are 
predictable to the extent that even advanced intermediate nonnative speakers can have strong intuitions about which form a plural will likely take. The following table illustrates a few of the most common broken plural skeletons in SAA. Note that all of the nouns in Table 10 below are masculine except for /xuḍra/ 'vegetable'.

Table 10

Examples of Broken Plural Forms

\begin{tabular}{|c|c|c|}
\hline$\underline{\text { Meaning }}$ & $\underline{\text { Singular }}$ & $\underline{\text { Plural }}$ \\
\hline vegetable & xuḍra (f) & xuḍārī \\
\hline bull calf & məșyar & mșāyar \\
\hline religious scholar & Jì & Jyūx \\
\hline fruit & fākiyah & fwākīh \\
\hline father & bābā & bābāwāt \\
\hline
\end{tabular}

\section{Suffixed pronouns}

In addition to the independent pronouns, which are used in the subject position or as emphatics, SAA has a set of corresponding suffixed pronouns. Suffixed pronouns are used in three different circumstances. If a noun has a suffixed pronoun, the pronoun indicates the 'owner' of the noun. If a verb has a suffixed pronoun, the pronoun functions as the direct object of the verb. Finally, if the pronoun is suffixed onto a preposition, the pronoun functions as the object of the preposition. 
McLain-Jespersen 24

Table 11

Independent and Suffixed Pronouns

\begin{tabular}{|c|c|c|c|c|}
\hline & \multicolumn{2}{|c|}{ Independent } & \multicolumn{2}{|c|}{$\underline{\text { Suffixed }}$} \\
\hline$\underline{\text { Person }}$ & $\underline{\text { Singular }}$ & $\underline{\text { Plural }}$ & $\underline{\text { Singular }}$ & $\underline{\text { Plural }}$ \\
\hline$\underline{1 \mathrm{st}}$ & Panə & ћnā & $-\overline{1},-y \bar{a},-n \overline{1}$ & -nā \\
\hline 2nd (m) & ntə & \multirow[t]{2}{*}{ ntūmā } & \multirow[t]{2}{*}{$-ə \mathrm{k},-\mathrm{k}$} & \multirow[t]{2}{*}{-kum } \\
\hline 2nd (f) & $\mathrm{nt} \overline{1}$ & & & \\
\hline$\underline{3 r d(m)}$ & huwa & \multirow[t]{2}{*}{ humm } & $-\mathrm{h},-\overline{\mathrm{u}}$ & \multirow[t]{2}{*}{-hum } \\
\hline 3rd (f) & hiya & & -hā, $\bar{a}$ & \\
\hline
\end{tabular}

As Table 11 above shows, the first person singular suffixed pronoun has three different forms. The form $/-\overline{1} /$ is used on words ending with a consonantal sound (/dār/ $\rightarrow$ /dār-ì/, "my house") while /-ya/ is used on words ending with a vowel sound (/fĩ/ $\rightarrow$ /fiya/, "in me"). However, /ya/ is not used on feminine marked nouns ending with /a/; these

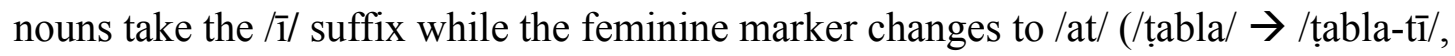
"my table"). Finally, the /-ni/ suffix is used as the direct object of verbs ( / RaSṭ/ $\rightarrow$ /RaYṭi-ni/, "give me") and the negative marker (/mij/ $\rightarrow$ /mif-ni/, "I'm not").

The second and third singular suffixed pronouns both have alternate forms as

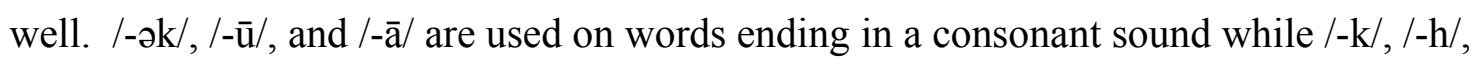
and /-hā/ are used on words ending in a vowel sound.

Table 12 below illustrates how suffixed pronouns are realized when attached to nouns, verbs and prepositions. Note that the feminine marker /a/ on /tabla/ becomes /at/ when it takes a suffixed pronoun. 
McLain-Jespersen 25

Table 12

Suffixed Pronouns Attached to Verbs, Nouns and Prepositions

\begin{tabular}{|c|c|c|c|}
\hline & Isolated form & $\underline{\text { Suffixed form }}$ & Translation \\
\hline \multirow[t]{3}{*}{$\underline{\text { Verbs }}$} & suwwəl & suwwəl-ni & he asked me \\
\hline & $3 \bar{a}$ & $3 \bar{a}-\mathbf{h}$ & he brought him \\
\hline & nћəbb & /nћəbb-ək/ & I love you \\
\hline \multirow[t]{3}{*}{$\underline{\text { Nouns }}$} & țabla (f) & țablat-nā & our table \\
\hline & Sṣā & Sșā-hā & her stick \\
\hline & kutūb & kutūb-hum & their books \\
\hline \multirow[t]{3}{*}{$\underline{\text { Prepositions }}$} & fĩ & fi-ȳa & in me \\
\hline & maSə & maSə-k & with you \\
\hline & taht & taht-nā & under us \\
\hline
\end{tabular}

Syntax

Below are the syntactic patterns of SAA relevant to this study.

The genitive construction

In SAA, possession and association can be shown either through the use of a genitive particle or via a genitive construction called an /Piḍāfa/. The most common method is through the genitive particle, /tā $\mathrm{S} /$ in urban speech and /ntās/ in rural dialects (as well as /djāl/, used in the most western parts of Algeria and all of Morocco).

Constructions with the genitive particle take the form of the 'possessed' noun, followed by the genitive particle, followed by the 'possessor.' This last element can either be another noun, as in the first three examples of Table 13 below, or a suffixed pronoun, as in the final three examples. 
Table 13

SAA Noun Phrases demonstrating the Genitive Construction Using the Genitive Particle

\begin{tabular}{|c|c|}
\hline$\underline{\text { SAA NP }}$ & $\underline{\text { Translation }}$ \\
\hline $\begin{array}{c}\int-\int 1 \mathrm{ix} \text { ntā } \text { əl-zāməS } \\
\text { DEF-sheik GEN DEF-mosque }\end{array}$ & the sheik of the mosque \\
\hline $\begin{array}{l}\text { d-drāhəm tā؟ əl-betrol } \\
\text { DEF-money GEN DEF-oil }\end{array}$ & the oil money \\
\hline $\begin{array}{l}\text { nās djāl wahrān } \\
\text { people GEN Oran }\end{array}$ & people of Oran (a city in Western Algeria) \\
\hline $\begin{array}{c}\text { 1-bīt tāe-i } \\
\text { DEF-room GEN-1SG.PRO }\end{array}$ & my room \\
\hline $\begin{array}{c}\text { əl-fikrə djāl-ū } \\
\text { DEF-idea GEN-3SG.PRO }\end{array}$ & his idea \\
\hline $\begin{array}{c}\text { t-tomobīil ntā؟-nā } \\
\text { DEF-car GEN-1PL.PRO }\end{array}$ & our car \\
\hline
\end{tabular}

The /Ridāafa/ construction, which is associated with MSA, occurs less frequently than the genitive particle in SAA. This construction is realized as a string of two or more nouns, the last of which is marked for definiteness. However, each noun in the / Piḍafa/ construction is considered definite. Table 14 below contains three examples of the /Riḍāfa/. In the second example, the feminine marker /a/ of the word /hakūma/ 'government' is realized as [ət] when preceding the definite article.

Table 14

SAA Noun Phrases Demonstrating the Genitive Construction Using the /Pidâfal

\begin{tabular}{|c|c|}
\hline$\underline{\text { SAA NP }}$ & Translation \\
\hline $\begin{array}{c}\text { bīt d-dār } \\
\text { room DEF-house }\end{array}$ & the room of the house \\
$\begin{array}{c}\text { ћakūmət əl-bled } \\
\text { government DEF-country }\end{array}$ & the government of the country \\
\hline $\begin{array}{c}\text { Jix əl-zāməS } \\
\text { sheik DEF-mosque }\end{array}$ & the sheik of the mosque \\
\hline
\end{tabular}


Noun-adjective agreement

Adjectives in SAA follow the noun they modify and agree in gender, number, and definiteness, as is shown in Table 15 below. In the fourth example, recall that /dār/ is one of the few feminine words in SAA that does not end in $/ \mathrm{a} /$.

Table 15

SAA Noun Phrases Demonstrating Noun-Adjective Agreement

\begin{tabular}{|c|c|}
\hline SAA NP & $\underline{\text { Translation }}$ \\
\hline $\begin{array}{l}\text { xedma mlīh-a } \\
\text { job.FEM good-FEM }\end{array}$ & a good job \\
\hline $\begin{array}{l}\text { 1-qamar oz-zwīn } \\
\text { DEF-moon DEF-pretty }\end{array}$ & the pretty moon \\
\hline $\begin{array}{c}\text { 1-muhandis-āt l-zdī̄d-āt } \\
\text { DEF-engineer-FEM.PL DEF-new-FEM.PL }\end{array}$ & the new engineers $(f)$ \\
\hline $\begin{array}{c}\text { d-dār əl-qadīm-a } \\
\text { DEF-house.FEM DEF-old-FEM }\end{array}$ & the old house \\
\hline $\begin{array}{l}\text { mudun kbār } \\
\text { city.PL big.PL }\end{array}$ & big cities \\
\hline
\end{tabular}

Sentence types

The three types of basic sentences in SAA that are relevant to this study are the verbal sentence, the equational sentence, and the existential sentence. Additionally, in order to fully comprehend these sentence types, an important distinction must be made between perfect and imperfect tenses.

The perfect tense refers to completed actions, and so it is generally thought of as the past. It is used in some situations that are not considered 'past' by native speakers of English, such as expressing comprehension, as in [fhəm-t] (understand.PERF-1SG) 'I understand.'

The imperfect tense refers to actions not yet completed and so is generally thought 
of as the present. Alone it can be used for expressing habitual behaviors, current actions, and near-future events. It is often combined with pre-verbs of time and place to clarify its exact intention.

\section{Verbal sentences}

A verbal sentence in SAA is one that has an overtly realized verb following the subject of the sentence. The subject of an SAA sentence can be an NP, a pronoun, or a pro-dropped pronoun. All three subject types are given in Table 16 below; the overt subjects are in boldface in the first two examples.

\section{Table 16}

Subject Types in SAA Verbal Sentences

\begin{tabular}{|c|c|c|}
\hline Subject Type & $\underline{\text { SAA Sentence }}$ & Translation \\
\hline NP & $\begin{array}{c}\text { l-bnāt jə-m Jî-w li-1-zāmi@a } \\
\text { DEF-girl.PL 3-go-PL to-DEF-university }\end{array}$ & $\begin{array}{l}\text { The girls go to the } \\
\text { university }\end{array}$ \\
\hline Pronoun & $\begin{array}{l}\text { humm jə-m } \int \overline{1}-w \text { li-1-zāmiৎa } \\
\text { 3.PL.PRO 3-go-PL to-DEF-university }\end{array}$ & $\begin{array}{l}\text { As for them, they go to } \\
\text { the university }\end{array}$ \\
\hline $\begin{array}{l}\text { Pro-dropped } \\
\text { pronoun }\end{array}$ & $\begin{array}{l}\text { jə-m } \sqrt{1}-w \text { li-l-zāmi@a } \\
\text { 3-go-PL to-DEF-university }\end{array}$ & They go to the university \\
\hline
\end{tabular}

A verbal sentence can be negated with the circumfixed negative particles /mā-... $-\int /$, which is placed before and after the verb (and all of its affixes). An illustration of the negation of verbal sentences is given in Table 17 below. 
McLain-Jespersen 29

Table 17

Negation of Verbal Sentences Using the Negative Particles

\begin{tabular}{|c|c|c|}
\hline Sentence type & $\underline{\text { SAA sentence }}$ & Translation \\
\hline Verbal sentence & $\begin{array}{l}\text { drīs ktəb } \\
\text { Driss write.PERF }\end{array}$ & Driss wrote. \\
\hline Negative verbal sentence & $\begin{array}{l}\text { drīs māa-ktəb- } \int \\
\text { Driss NEG-write.PERF-NEG }\end{array}$ & Driss didn't write. \\
\hline $\begin{array}{l}\text { Verbal sentence with } \\
\text { affixes }\end{array}$ & $\begin{array}{l}\text { drīs je-ktəb-hā } \\
\text { Dirss 3M.IMPER-write-3FEM.OBJ }\end{array}$ & Driss writes it. \\
\hline $\begin{array}{c}\text { Negative verbal sentence } \\
\text { with affixes }\end{array}$ & $\begin{array}{l}\text { drīs mā-je-ktəb-hā- } \int \\
\text { Driss NEG-3M.IMPER-write- } \\
\text { 3FEM.OBJ-NEG }\end{array}$ & $\begin{array}{l}\text { Driss doesn't } \\
\text { write it. }\end{array}$ \\
\hline
\end{tabular}

\section{Equational sentences}

The second important type of sentence is the equational sentence. The simplest form of this sentence involves a definite subject followed by an indefinite predicate that agrees with the subject in gender and number and is in the imperfect tense. The predicate can be an adjective, noun, or participle. The equational sentence equates the subject and the predicate, as in 'A is B.' However, in the imperfect equational sentence, the copula 'be' is not overtly realized. In the perfect tense of an equational sentence, the verb /kān/ 'is' (lit. 'was') occurs between the subject and the predicate. In order to negate an imperfect tense equational sentence, the negative particle $/ \mathrm{ma} / \mathbf{j} /$ 'not' is inserted between the subject and the predicate. To negate a past tense equational sentence, $/ \mathrm{kān} /$ must be circumfixed with the negative particles /mā-...-S/. Table 18 below shows equational sentences in present, past and negated forms. 
Table 18

Equational Sentences in Present, Negative Present, Past, and Negative Past Tenses

\begin{tabular}{|c|c|}
\hline$\underline{\text { Tense }}$ & SAA equational sentence \\
\hline$\underline{\text { Imperfect }}$ & $\begin{array}{l}\text { əl-makla yāli-a } \\
\text { DEF-food.FEM expensive-FEM } \\
\text { 'food is expensive' }\end{array}$ \\
\hline Negative Imperfect & $\begin{array}{l}\text { əl-makla māễ yāli-a } \\
\text { DEF-food.FEM NEG expensive-FEM } \\
\text { 'food is not expensive' }\end{array}$ \\
\hline$\underline{\text { Perfect }}$ & $\begin{array}{l}\text { əl-makla kān-ət yāli-a } \\
\text { DEF-food.FEM be.PERF-3F expensive-FEM } \\
\text { 'food was expensive' }\end{array}$ \\
\hline$\underline{\text { Negative Perfect }}$ & $\begin{array}{c}\text { əl-makla mā-kān-ət- } \int \text { yāli-a } \\
\text { DEF-food.FEM NEG-be.PERF-3F-NEG expensive-FEM } \\
\text { 'food was not expensive' }\end{array}$ \\
\hline
\end{tabular}

Existential sentences

Existential sentences are a subtype of equational sentence in that the copula is not overtly realized. There are two existential particles that can be used to indicate an existential sentence: /kājən/ and /fīh/ 'there is.' The particle /kājən/ agrees in number and gender with the grammatical subject of the existential sentence and thus can take gender and number markers, resulting in /kājn-a/ 'there is '(fs) and /kājn-īn/ 'there are' (pl), respectively. The particle /fïh/ is invariable and used in SAA at a much lower frequency than /kājən/.

When an imperfect tense existential sentence is negated, the circumfixed negative particles /mā... / surround the existential particle as in /mā-kājon- $\int /$ or /mā-fīh- $\int /$ 'there is not'. When the existential sentence is in the perfect tense, /kān/ 'was' comes before the existential particle and agrees with the grammatical subject. In this case, /fîh/ is used at a much higher frequency than /kājən/. The perfect tense existential sentence has /kān/ 
surrounded by the circumfixed negative particles. Table 19 below details all of the above existential sentence forms.

\begin{tabular}{|c|c|c|}
\hline Imperfect & $\begin{array}{l}\text { kājən 1-hanūt } \\
\text { there.is DEF-store } \\
\text { 'there is a store' }\end{array}$ & $\begin{array}{l}\text { fîh 1-ћarb təmma } \\
\text { there.is DEF-war there } \\
\text { 'there is a war there' }\end{array}$ \\
\hline$\frac{\text { Negative }}{\text { Imperfect }}$ & $\begin{array}{l}\text { mā-kājon- } \int 1-\hbar a n u ̄ t \\
\text { NEG-there.is-NEG DEF-store } \\
\text { 'there is not a store' }\end{array}$ & $\begin{array}{l}\text { mā-fîh- } \int 1-\hbar a r b \text { təmma } \\
\text { NEG-there.is-NEG DEF-war there } \\
\text { 'there is not a war there' }\end{array}$ \\
\hline$\underline{\text { Perfect }}$ & $\begin{array}{l}\text { kān fìh 1-hanūt } \\
\text { be.PERF there.is DEF-store } \\
\text { 'there was a store' }\end{array}$ & $\begin{array}{l}\text { kān fìh 1-harb təmma } \\
\text { be.PERF there.is DEF-war there } \\
\text { 'there was a war there' }\end{array}$ \\
\hline$\frac{\text { Negative }}{\underline{\text { Perfect }}}$ & $\begin{array}{c}\text { mā-kān- } \int \text { fīh 1-hanūt } \\
\text { NEG-be.PERF-NEG there.is DEF-store } \\
\text { 'there was not a store' }\end{array}$ & $\begin{array}{l}\text { mā-kān- } \int \text { fīh 1-harb təmma } \\
\text { NEG-be.PERF-NEG there.is DEF-war there } \\
\text { 'there was not a war there' }\end{array}$ \\
\hline
\end{tabular}

\section{The Grammar of French}

The codeswitching in the data of this study is primarily between SAA and French. Below, I give an explanation of how I dealt with the issue of borrowing versus codeswitching. In order to inform the discussion on the French items found in the data, I then discuss the phonological and morphological processes that French words undergo when codeswitched into otherwise SAA utterances. The grammatical section below was informed by Keddad's (1986) study on codeswitching between French and SAA. Her data were from the speech of her friends in Algiers, and, thus, her results are discussed here only as general examples of French use in Algeria. 
McLain-Jespersen 32

Borrowing Versus Codeswitching Between French and SAA

Due to the complex history of language contact in Algeria, the French or Frenchorigin forms used by SAA speakers fall all along a continuum between codeswitching and borrowing (cf. Myers-Scotton 1992). According to Myers-Scotton (1992), a borrowed form refers to a single lexeme from the embedded language (EL). She claimed that a borrowed form was once a CS form that had since become a part of the lexicon of the ML and that the primary difference between the two forms is one of predictability: since borrowed forms have been entered into the ML lexicon, they can be predicted to appear routinely and eventually be integrated within the ML's phonology and morphosyntax.

The question of how to differentiate between borrowed and CS forms for the purposes of this study remains. The traditional criterion for teasing the two categories of forms apart was phonological integration. However, Myers-Scotton continuously argued that while the majority of borrowed forms are integrated, phonology does not provide suitable predictability for these forms due to various sociolinguistic circumstances which could effect the pronunciation of a borrowed word. As discussed below, French words in this study's data set, whether codeswitched or borrowed, show at least some degree of phonological integration when used in otherwise SAA utterances. Therefore, as MyersScotton stated, frequency is the best way of establishing whether a lexeme has progressed from a CS form to borrowed form.

However, in the present study, it would be foolish to argue for one form over the other based solely on the frequency counts within my limited corpus. The 
analysis used in this study recognized that both borrowed and codeswitched forms may show phonological and morphological integration; therefore, sociolinguistic factors are what differentiate the two forms. Thus, French words used in SAA that show phonological or morphological integration cannot be determined to be borrowed or codeswitched forms based on the presence of integration alone. Based on all of the above factors, I have decided to ignore this distinction and refer to cases of French words used in SAA as 'codeswitching,' particularly since I am not making arguments that hinge on this distinction.

\section{Phonological integration}

When speakers of SAA use French words in SAA, the words they use often undergo phonological alteration. Keddad (1986) described systematic replacement of French consonants and vowels with SAA consonants and vowels in French words in the data used for her study of CS between French and SAA. The following phonological examples are adapted from Keddad's text (pp. 160-179), with some transcription adjustments.

Due to the influence of the French language, speakers of SAA will occasionally use three borrowed sounds not otherwise found in SAA or other varieties of spoken Arabic: the bilabial voiceless stop /p/, the labio-dental voiced fricative /v/, and the uvular voiced fricative /в/. As will be discussed below, these sounds are rarely used. In fact, speakers of SAA will often replace these sounds with corresponding SAA ones (/b/, /f/, and /r/, respectively) when uttering French words. However, according to Keddad (1986) 
there are instances recorded in which these French sounds have been used in SAA words by an SAA native speaker.

\section{Consonants}

When French words are used in an otherwise SAA utterance, certain consonants are often replaced with an SAA equivalent. Table 20 below shows some examples adapted from Keddad (1986).

Table 20 Replacement of Consonants in French Words Used in SAA

\begin{tabular}{|c|c|c|}
\hline French pronunciation & $\underline{\text { SAA pronunciation }}$ & Meaning \\
\hline [раsрок] & [basbur] & passport \\
\hline [televizjõ] & [tilifizjun] & television \\
\hline [savõ] & [șabun] & soap \\
\hline [taksi] & [țaksi] & $\operatorname{taxi}$ \\
\hline [dam] & [ḍama] & cards \\
\hline [salõ] & [șalun] & sitting room \\
\hline [fus $\left.\int \varepsilon t\right]$ & [furfita] & fork \\
\hline
\end{tabular}

These consonantal shifts demonstrate the place of French as not just another foreign language in Algeria. Emphatic consonants are a distinctive aspect of the sounds of Arabic. Keddad argued that the transfer of /t/, /d/, and /s/ to /ț/,/ḍ/, and /ṣ/ represented "re-nativation" (pg. 169) which served to index the identity of these French words to SAA. Likewise, Keddad also noted the presence of the voiced alveolar trill $/ \mathrm{r} /$ of SAA in place of its French counterpart $/ \mathrm{b} /$ in monolingual French utterances of SAA speakers; however, SAA does contain a voiced velar fricative which is quite close to the French $/ \mathrm{s} /$. 
Thus, the use of the SAA/r/ in these cases is likely an effort to avoid sounding French

Vowels

When French words are used in an otherwise SAA utterance, certain vowels not found in SAA are often replaced by SAA equivalents. Nasal vowels are replaced by an SAA equivalent and a nasal consonantal sound. Table 21 below is adapted from Keddad (1986) and shows both cases.

\section{Table 21}

Replacement of Vowels in French Words Used in SAA

\begin{tabular}{|c|c|c|}
\hline French pronunciation & $\underline{\text { SAA pronunciation }}$ & Meaning \\
\hline lãp & lamba & light bulb \\
\hline tьãkil & trankil & peacefully \\
\hline tь $\tilde{\varepsilon}$ & $\operatorname{tr\varepsilon n}$ & train \\
\hline t $\tilde{\varepsilon}$ bь & tembr & stamp \\
\hline balo & balun & balloon \\
\hline sinema & sinima & cinema \\
\hline тевœь & tirur & terror \\
\hline мув & sur & sure \\
\hline
\end{tabular}

Morphological integration

Keddad (1986) found that three SAA bound morphemes are routinely produced on codeswitched French nouns: the definite article, the gender marker, and the number marker. French verb stems can take SAA affixes in order to become adjectives. In addition, French verb stems are conjugated in SAA as if they were SAA finally weak verbs. 
The Definite Article

The definite article in French is marked for gender and number. It agrees with the noun it is modifying. The forms of the definite article are provided in Table 22 below:

Table 22

The Definite Article in French

\begin{tabular}{|c|c|c|}
\hline & $\begin{array}{c}\text { Preceding a consonant } \\
\underline{\text { sound }}\end{array}$ & $\begin{array}{c}\text { Preceding a vowel } \\
\text { sound }\end{array}$ \\
\hline Masculine singular & $\begin{array}{l}\text { lə fRomaz } \\
\text { DEF.MSG cheese } \\
\text { 'le fromage' }\end{array}$ & \multirow[t]{2}{*}{$\begin{array}{c}\text { l-usīn } \\
\text { DEF.SG-factory } \\
\text { 'l'usine' }\end{array}$} \\
\hline$\underline{\text { Feminine singular }}$ & $\begin{array}{l}\text { la pisin } \\
\text { DEF.FSG pool } \\
\text { 'la piscine' }\end{array}$ & \\
\hline$\underline{\text { Masculine and feminine plural }}$ & $\begin{array}{c}\text { le perji } \\
\text { DEF.PL country.PL } \\
\text { 'les pays' }\end{array}$ & $\begin{array}{c}\text { lez-usīn } \\
\text { DEF.PL-factory.PL } \\
\text { 'les usines' }\end{array}$ \\
\hline
\end{tabular}

When a definite French noun is used in an otherwise SAA utterance, the SAA definite article cliticize to it as if it is an Arabic noun. That is, if the French noun begins with a phonological equivalent of a moon letter as described above, the definite article is realized as either [əl] or [1]. In Figure $\mathrm{C}$ from the data of this study below, the SAA definite article is cliticized to the French word primaire. Since primaire is analyzed as a moon letter, the definite article is realized as [1]. Later in the same line, the SAA definite article is cliticized to the French word secondaire, which begins with the phonological equivalent of the sun letter /s/, causing the definite article to be realized as [s]. 
Figure C: Sun and Moon Letters on Definite Articles Modifying French Nouns [3āb-ū drāri syār təS l-primer bring.PERF-PL children small.PL GEN DEF-elementary and DEF-secondary "They brought the small children from elementary school and middle school" ("Blad Miki")

\section{Gender marking}

Like Arabic, French has grammatical gender and are either masculine or feminine. The gender of a noun is not always predictable by its morphological form, and even more difficult to predict based on its spoken realization. However in most cases, the gender of a noun can be determined by the pronunciation of its article, as in Table 22 above.

French nouns codeswitched into otherwise SAA utterances are marked for gender via SAA morphology. Masculine nouns remain unmarked, and the SAA feminine marker /a/ is added to feminine nouns. These changes are the sole way of marking the gender of these codeswitched nouns, since the article they take will be from Arabic and not from French. The difference between how masculine and feminine nouns appear normally and when they are codeswitched into SAA is provided in Table 23 below.

Table 23

French Gender Marking on Nouns Codeswitched into SAA

\begin{tabular}{|c|c|c|}
\hline $\begin{array}{c}\text { French definite noun } \\
\text { beginning with "sun letters" }\end{array}$ & SAA equivalent & Meaning \\
\hline lo tsak (m) & ot-trak & nerves (Eng.) \\
DEF.M.SG nervousness & DEF-nervousness & le trac (Fr.) \\
\hline la bas (f) & or-ras-a & race (Eng.) \\
DEF.F.SG race & DEF-race-FEM & la race (Fr.) \\
\hline
\end{tabular}


Number marking

French nouns are only marked for number orthographically with the suffix '-s' which is not pronounced except in some cases of liaison when the following word begins with a vowel sound. The article attached to the noun agrees in number; thus, the difference between a singular and plural article can be heard in speech and the plurality of a noun is understood.

Plural French nouns used in SAA that take the SAA definite article are marked for plural with the SAA plural markers $/ \overline{1} \mathrm{n} /$ and /āt/. Generally, non-human plurals take the /ât/ ending regardless of gender, and human plurals can take both the /în/ and /ât/ ending as is illustrated in Table 24 below.

Table 24

French Definite Plural Nouns Codeswitched into SAA

\begin{tabular}{|c|c|c|}
\hline French definite plural noun & SAA equivalent & Meaning \\
\hline $\begin{array}{c}\text { le } \int a ̃ b s \\
\text { DEF.PL room.PL }\end{array}$ & $\begin{array}{c}\text { f-fambr-āt } \\
\text { DEF-room-F.PL }\end{array}$ & $\begin{array}{c}\text { the rooms (Eng.) } \\
\text { les chambres (Fr.) }\end{array}$ \\
\hline $\begin{array}{c}\text { le tabl } \\
\text { DEF.PL table.PL }\end{array}$ & $\begin{array}{c}\text { t-țabl-āt } \\
\text { DEF-table-F.PL }\end{array}$ & $\begin{array}{c}\text { the tables (Eng.) } \\
\text { les tables (Fr.) }\end{array}$ \\
\hline $\begin{array}{c}\text { le zãdarm } \\
\text { DEF.PL policeman.PL }\end{array}$ & $\begin{array}{c}\text { l-zadarmij-in } \\
\text { DEF-policeman-MPL }\end{array}$ & $\begin{array}{c}\text { the policemen (Eng.) } \\
\text { les gendarmes (Fr.) }\end{array}$ \\
\hline $\begin{array}{c}\text { le farmasjen } \\
\text { DEF.PL pharmacist.FPL }\end{array}$ & l-farmasjan-āt & $\begin{array}{c}\text { the pharmacists (Eng.) } \\
\text { les pharmaciennes (Fr.) }\end{array}$ \\
\hline
\end{tabular}

\section{Participle creation}

In SAA, verbs can be made into participles by adding the prefix $/ \mathrm{m}-/$ (which is realized as $[\mathrm{m}]$ or $[\mathrm{m} ə]$, depending on the context) and an affix that agrees with the noun it is modifying, either /-i/ (masculine singular), /-a/ (feminine singular), /-īn/ (masculine 
plural), or /-ât/ (feminine plural). In SAA, French verbs stems are altered in the same way. The tense of the participle depends on the tense of the sentence. Table 25 below shows three examples from the data of this study.

Table 25

SAA Participles Created from French Verb Stems

\begin{tabular}{|c|c|c|c|}
\hline $\begin{array}{c}\text { French infinitive } \\
\text { verb }\end{array}$ & Verb definition & $\underline{\text { SAA participle }}$ & Meaning \\
\hline bloquer & to block & $\begin{array}{c}\text { m-blok-i } \\
\text { PARTIC-block-MSG }\end{array}$ & blocked / blocking \\
\hline tracer & to draw & $\begin{array}{c}\text { mə-tras-i } \\
\text { PARTIC-plan-MSG }\end{array}$ & planned / planning \\
\hline stocker & to save & $\begin{array}{c}\text { mə-stok-i } \\
\text { PARTIC-save-MSG }\end{array}$ & saved / saving \\
\hline
\end{tabular}

\section{Verb conjugation}

As noted, French verbs that are used in an otherwise SAA utterance are treated as SAA finally weak verbs when conjugated in SAA. That is, the final /e/ sound, represented by '-er' of the infinitive French verb, can be considered the 'weak radical' and is lost in conjugation. All -er verbs in French can be conjugated into SAA regardless of their frequency within the language. The following table shows the conjugation chart for the French verb forcer ([fəьse]) 'to force,' found in the data of this study. In this case, the $/ \mathrm{o} /$ vowel sound is realized as $[\mathrm{o}]$ and the $/ \mathrm{b} /$ consonant sound is realized as $[\mathrm{r}]$. The result is a verb stem of /forse/, with a functional Arabic root of /f/, /s/, /e/. Table 26 below provides a conjugation chart for this verb. 
Table 26

Conjugation Chart for /forse/ ("he forced")

\begin{tabular}{|c|c|c|c|c|}
\hline \multirow{2}{*}{} & \multicolumn{2}{|c|}{ Perfect (past tense) } & \multicolumn{2}{c|}{ Imperfect (present tense) } \\
\cline { 2 - 5 } & Singular & $\underline{\text { Plural }}$ & $\underline{\text { Singular }}$ & $\underline{\text { Plural }}$ \\
\hline$\underline{\text { 1st Person }}$ & forsit & forsīnā & nforsi & nforsīw \\
\hline 2nd Person (m) & & forsītū & təforsi & təforsīw \\
\hline$\underline{\text { 2nd Person (f) }}$ & forsitī & & & \\
\hline 3rd Person (m) & forsi & forsāw & jforsi & jforsīw \\
\hline$\underline{\text { 3rd Person (f) }}$ & forsāt & & təforsi & \\
\hline
\end{tabular}

These patterns of codeswitching French into SAA discussed in the section above represent a variety of strategies native speakers of SAA have that allow them to use French lexical items commonly. Due to the long history of contact between SAA and French, native speakers of SAA see much of the French they use day to day as nativized; that is, the French words they use may not be Arabic, but they are Algerian. This fact presents a roadblock for distinguishing between CS and borrowed forms in SAA, and, as I discuss below, it is one of the reasons I choose to forgo making that distinction for my analysis.

\section{Hip Hop in Algeria}

Below is a brief treatment of the history of rap music, the linguistic tendencies of the lyrics of rap songs, and the state of rap in Algeria.

Rap is a style of music that was born in the late 1970's in economically depressed areas of New York City. The culture that surrounds rap music is often referred to as hip hop. While hop hop and rap are often used interchangeably, in this study I use the term 'rap' to refer to the music and the term 'hip hop' to refer to the culture. Rap is 
characterized by a spoken word performance over an electronically produced beat. While rappers often use a conversational style in their performance, the lyrics in rap music are highly poetic, often utilizing many different kinds of rhymes and alliterations. Rap artists pride themselves on the complexity and creativity of the wordplay and rhymes in the lyrics they write (Bradley, 2009). Rap lyrics often contain slang, non-standard grammatical forms, and vulgarities, patterns which are seen cross-linguistically and cross-culturally.

There have been numerous studies on the language of rap music. Researchers have analyzed rap lyrics that include socially stigmatized language varieties (such as African American Vernacular English (Smitherman, 1997; Alim, 2002 \& 2003; Low, 2007; Magnusson, 2008; Cutler, 2010)), and/or employ stigmatized language practices such as CS in places like Montreal (Sarkar \& Winer, 2005), Newfoundland (Clarke \& Hiscock, 2009), France (Paine, 2012), Tanzania (Fenn \& Perullo, 2000), Burma (Keeler, 2009), and Australia (Warren \& Evitt, 2010).

The spread rap to the Arabic-speaking world is a well documented phenomenon (Kahf 2007, Daragahi \& Fleishman, 2009). Coming from France into francophone North Africa, it quickly made its way to the eastern edge of the Middle East. It has been documented in almost every Arabic-speaking country from Morocco (Al Arousni, 2007; Belhaj, 2007) and Algeria (Daoudi, 2000; Fariborz, 2005) to Iraq (Joshi, 2009; Lebouachera, 2009) and Saudi Arabia (Ambah, 2008).

Rap in Algeria has been claimed as starting on October 5, 1988, the date of widespread youth protests against the government (Fariborz, 2005). The youth who 
experienced violent clashes with police formed a politically active generation. Through the 90 's, the violent atmosphere of the Algerian civil war provided a backdrop to the songs of the increasing number of rap groups in Algeria. After the civil war ended in 1999, much of the rap music tended to focus on the disillusionment many feel with the government because of the amnesty made with Islamists, steep unemployment, and problems in the education system (Davies \& Bentahila, 2006).

Rap is now widespread in Algeria. It can be found in every town, even in some rural villages in the Tamazight-speaking region of Kabylie (Fariborz, 2005). Daoudi (2000) describes Algeria as the "rap leader" (p. 34) of the Arabic-speaking world. Intik and Le Micro Brise Le Silence ('The Microphone Breaks the Silence', commonly abbreviated as 'MBS') are named as two pioneering Algerian rap groups, while the rap group Double Kanon (the subject of this study) is "considered the best" (p. 35) in Algeria.

Davies and Bentahila (2006) wrote on the discourse patterns of CS in North African rap. They described North African rap as often using a conversational style dominated by codeswitching from a spoken variety of Arabic into a European language (most often French.) Their research, however, only examined the social implications of codeswitching in rap lyrics. While the importance of the social use of language cannot be ignored, the gap in the research on CS in North African hip hop lies in structural analysis of the switching itself. This study aims to better understand the patterns of codeswitching present in the rap lyrics of an artist that has a wide reach across the youth demographic in Algeria. 


\section{Codeswitching}

Codeswitching (CS) has been defined as "the use of more than one language in the course of a single communicative episode" (Heller, 1998, p. 1). Two main approaches to CS research have been identified (Woolard, 1988; Boumans, 1998; Gardner-Chloros, 2009): that of social description and structural analysis. Gardner-Chloros (2009) stated that the majority of CS research is based in social description, while structural analysis is not a primary focus. The majority of the literature on CS has focused on switching produced in an informal conversational context. However, research has been conducted on CS in poetry (Mendieta-Lombardo, \& Cintron, 1995), popular literature (Geider, 2005), stand up comedy (Woolard, 1988), lyrics in popular music (Davies, \& Bentahila, 2006; 2008), and literary texts (Myers-Scotton, 1998).

\section{Structural Constraints on CS}

Researchers such as Myers-Scotton (1993, 1993b) have focused on the structural constraints of CS since the early 1980s. There are two main approaches to the grammatical study of CS: a linear approach and an insertion approach. The linear approach investigates switches based on surface structure word order, the main focus being word order around the point of the switch. An early and influential contribution to the linear approach was Sankoff and Poplack's (1981) formulations of the Free Morpheme Constraint, which dictates that switching cannot occur between bound morphemes, and the Equivalence Constraint, which dictates that the word order on either side of the switch point must be grammatical in each participating language. Boumans 
(1998) outlined some of the general and well known shortcomings of the linear approach and why they underline the need for a insertional approach to the analysis of CS. First, the linear approach's focus on word order is highly uneconomical. Formulating word order constraints would require enumerating all of the various possible word categories that could surround a switch site. Second, in order to explain some problematic data from CS corpora of linguistically dissimilar languages, Poplack and Sankoff (1988) redefined much of the problematic data as either nonce borrowings or inserted constituents rather than reformulating their model. This restricting of what constitutes "actual" CS represents a pattern for Poplack and her associates' work. The final shortcoming Boumans noted was that linear models do not recognize the asymmetrical role that each language plays in CS, which is a central theme in the study of language contact situations.

In contrast, insertion approaches recognize this asymmetrical relationship as an essential facet of CS. Joshi (1985) was the first to suggest that in a stretch of discourse, one language plays a larger role than the other. Joshi termed the language playing the larger role as the 'host' language and the language playing a secondary role as the 'guest' language. This distinction would come to be known as the Matrix Language (ML) and Embedded Language (EL) respectively in the works of Myers-Scotton. Insertion approaches are based on the idea that the ML first creates a frame and lexical items or entire well formed constituents of the EL are then inserted into it. A crucial aspect to understanding this relationship is the distinction between content morphemes and system morphemes (also called content words and function words, or open class words and 
closed class words respectively). Content morphemes are generally nouns, verbs, and adjectives. System morphemes include prepositions, determiners, and articles and typically serve to express grammatical relationships between content morphemes. Insertion approaches generally assume a basic framework based on Garrett's (1976) language production model. In this adaptation of Garrett's model, lemmas from the ML containing semantic information are selected in an early stage of production. The information from these lemmas are fed into what is referred to as the formulator and are used to build a morphosyntactic frame made up of ML system morphemes and based on ML word order rules. Once the frame has been realized, the content morphemes from both the ML and the EL can then be inserted. The content morphemes from the ML are inserted before the ones from the EL. A single EL lexeme can be fully integrated into the ML morphosyntax. It can also appear adjacent to another single EL lexeme and show structural dependency to the it based on EL grammar. These instances are referred to as EL Islands and are discussed below.

In the literature on CS generally, two types of CS have long been identified: intersentential switching and intrasentential switching. Intersentential CS occurs when a switch occurs between sentences. Intrasentential CS occurs when a switch occurs within a sentence. Myers-Scotton and Jake (1995) have since acknowledged a major shortcoming in using the sentence as the basic this unit of analysis: in intrasentential CS, it is possible that the grammars of the two languages do not interact. Figure 1 below is a single sentence, but it is clear that the complementizer phrases (each CP surrounded by curly brackets) in the second sentence involve different languages and their grammars are 
kept apart.

Figure 1: An Example of Codeswitching Between CPs

\{ça va rien résoudre $\}$ \{çava aggraver les problèmes $\}$ it go.PRES.3SG nothing resolve.INF, it go.PRES.3SG aggravate.INF DEF.PL problem.PL, "It's not going to solve anything. It's only going to make the problems worse"

\{lā xāțši n-nās rāyḥ-īn i-weddr-u nās min Gāyl-āt-hum\} NEG because DEF-people FUT-PL 3M-lose-PL people from family-PL-3PL.POS "Because people are going to lose members of their families."

Spoken Algerian Arabic/French (Bergman, 2005, p. 287).

In Figure 1 above, there is a well formed monolingual French $\mathrm{CP}$ adjacent to a well formed monolingual SAA CP. Because of data such as Figure 1 above, MyersScotton and Jake redefined the proper unit of analysis for structural models of CS as the CP. Therefore, "inter-CP" replaced "intersentential" and "intra-CP” replaced “intrasentential.” Under this new analysis, Figure 1 would no longer be considered intrasentential CS, but inter-CP CS. Inter-CP CS occurs when two monolingual CPs are dominated by the same CP.

In contrast, Intra-CP CS occurs when a single CP contains more than one language. According to Myers-Scotton (2002), a bilingual CP is a CP that "(i) contains one or more constituents (including other CPs) that are mixed constituents or (ii) contains one or more Embedded Language Islands that it dominates" (56). Figure 2 below is an example of intra-CP CS, as it contains a single CP containing both SAA and French (in italics). 
Figure 2: An Example of Intra-CP CS

lla télévision/ [tā̧ d-dzāyr tā̧ 1-ḥukūma]

DEF.FEM television GEN DEF-Algeria GEN DEF-government.

"Television in Algeria belongs to the government."

Spoken Algerian Arabic/French (Bergman, 2005, pg. 138).

The insertion approach to CS would analyze Figure 2 above as a CP made up of a frame of system morphemes from SAA into which both SAA and a French EL Island made of a system morpheme and a content morpheme were inserted. In order to predict the possible patterns of these insertions, Myers-Scotton (1993) constructed a model called the Matrix Language Frame (MLF) model.

\section{The MLF model}

Myers-Scotton made significant contributions to the insertion approach of codeswitching with a series of papers that eventually yielded the volume Dueling Languages (1993). In it, Myers-Scotton proposed and elaborated on the MLF model.

Like the insertion approaches it stems from, the MLF Model is based upon two oppositions: the difference between the ML and the EL, on the one hand, and the difference between a content and a system morpheme, on the other. The MLF model posited that a morphosyntactic frame is built of ML system morphemes and that EL and ML content morphemes are then inserted into it. Myers-Scotton (1993) stated that the ML could be determined by a "frequency-based criterion" (pg. 68); that is, the language that contributes more overall morphemes in a discourse passage is the ML. This distinction would later prove problematic and would be refined, which is a discussion that 
is held in the subsequent section.

According to the model, the insertion process described above yields two types of constituents: EL Islands and mixed (ML + EL) constituents.

EL islands were defined as constituents made up of multiple EL morphemes which show dependency according to EL grammar, but are otherwise contained within an ML CP. In Figure 3 below, the French NP 'la télé' ('the television') has been inserted into an SAA frame, as was the case in Figure 2 above. The two French morphemes show structural dependency to each other and are contained within their own NP node; while they are also under the PP node associated with the ML preposition / $\mathrm{Ga}$ / 'about', they do not interact with any ML morphemes in this example.

Figure 3: An Example of a French EL Island Code-switched into an SAA CP

[mā-t-Sawəl- $\quad$ Sa] /la télél

NEG-2SG-trust-NEG about DEF television

"Don't trust the television."

("Ani Jay")

A mixed constituent, on the other hand, occurs when a single EL lexeme is inserted into the ML frame. This rule was codified with the ML Hypothesis:

As an early step in constructing ML + EL constituents, the ML provides the morphosyntactic frame of ML + EL constituents (Myers-Scotton, 1993, pg. 82).

Myers-Scotton provided two testable principles in order to verify the ML

Hypothesis.

The Morpheme-Order Principle: In ML + EL constituents consisting of singlyoccurring EL lexemes and any number of ML morphemes, surface morpheme order (reflecting surface syntactic relations) will be that of the ML.

The System Morpheme Principle: In ML + EL constituents, all system morphemes which have grammatical relations external to their head constituent (i.e. which 
participate in the sentence's thematic role grid) will come from the ML (1993, pg. 83).

In Figure 4 below, a single French lexeme has been inserted into a frame made up of SAA system morphemes.

Figure 4: An Example of a French Lexeme Code-switched into an SAA CP [te-lga d-donya mif] /normall 2SG.IMPERF-find DEF-world NEG.PART normal "You find the world is not normal." ("Blad Miki")

In Figure 4 above, I have analyzed the ML as being SAA. First, the morpheme order is that of SAA. Secondly, the SAA verb /ga/ 'find' shows agreement with the subject, a pro-dropped second-person singular pronoun, via the SAA system morpheme, a verbal prefix, /t $\varepsilon /$; therefore $/ \mathrm{t} \varepsilon /$ has grammatical relations outside its head constituent. Thus, both the Morpheme-Order Principle and the System-Morpheme Principle are satisfied, and the ML is clearly SAA.

While the previous case of determining the ML was a straightforward one, the process is not always so simple. The question of how to determine just which language is acting as the ML in intra-CP CS has been a hotly debated topic, as well the subject of reinterpretations by Myers-Scotton. As noted, in the original version of the MLF model, Myers-Scotton (1993) wrote that the ML could be identified based on whatever language contributed more morphemes over a stretch of discourse, which was determined to be "more than one sentence" (68). This seemingly arbitrary required length for a discourse sample to be considered appropriate was problematic because texts are created out of sentences and utterances that must be generated CP by CP. The ML being defined based 
on morpheme count was problematic because it failed to consider the ramifications of the System Morpheme Principle of the MLF model. That is, if the only morphemes that absolutely must come from the ML are system morphemes with grammatical relations outside their head constituents, then the language providing the greater number of morphemes of any type in a passage may not necessarily be the ML.

In order to try to clarify the definition of the procedure for determining the ML, Myers-Scotton and Jake (1995) stated that: "The first criterion is this: the ML is the language that projects the morphosyntactic frame for the $\mathrm{CP}$ that shows intrasentential code switching" (p. 983) and that this criterion is "operationalized as the morpheme order and system morpheme principles of the MLF model" (p. 983). These are the principles I followed above to determine that SAA was the ML of Figure 4. Boumans (1998), among others, outlined the circular nature of this method of defining the ML. He wrote that "it can be no longer presented as a hypothesis that the ML projects the morphosyntactic frame" (p. 39) if in order to determine the ML one must identify which language is projecting the morphosyntactic frame.

To date, there has not been a fully sufficient definition of the ML. In fact, defining the ML based on the morpho-syntactic structure of the sentence inherently runs the risk of being circular. Fledgling neurolinguistic research on bilingualism has indicated that in the future it may be possible to determine the ML of an utterance based on brain scan data (Price, Green \& von Studnitz, 1999). However, until that kind of evidence becomes viable, there is no unproblematic way of identifying the ML. That is not to say that the idea of a matrix language should be abandoned, however. It is 
currently the most productive model of CS that is available and accounts for a wide swath of CS data.

\section{4-M model}

Expanding on Garrett's (1976) model of language production and incorporating conclusions drawn from numerous CS studies since the publication of Dueling Languages, Myers-Scotton and Jake (2000) formulated the Four Morpheme (4-M) Model in order to further clarify the content/system morpheme distinction. While the 4-M Model was designed to be considered separate from the MLF Model, it provides clarification of the System Morpheme Principle.

Under the 4-M Model, system morphemes were defined to be of three types: early system morphemes (ESM), outsider late system morphemes (OLSM) and bridge late system morphemes (BLSM). In addition to the system morphemes, there is a single type of content morpheme. These new classifications were distinguished from one another via three axes: thematic role assignment, conceptual activation, and reference to information outside the head. Table 27 below summarizes each new morpheme distinction.

Table 27

Morpheme Types in the 4-M Model

\begin{tabular}{|c|c|c|c|}
\hline Morpheme type & $\frac{\text { Thematic role }}{\underline{\text { assignment }}}$ & $\frac{\underline{\text { Conceptual }}}{\text { activation }}$ & $\begin{array}{c}\frac{\text { Reference to }}{\text { information outside }} \\
\text { of the head }\end{array}$ \\
\hline Content & + & + & - \\
\hline Early System & - & + & - \\
\hline Bridge Late System & - & - & - \\
\hline Outside Late System & - & - & + \\
\hline
\end{tabular}


Content morphemes and early system morphemes are associated in that they are both conceptually activated; that is they are elected early in Garrett's language production process at the lemma level. In contrast, two kinds of late system morphemes are not conceptually activated and must wait until later in the psycholinguistic production process to find their proper form. Bridge late system morphemes reference information within their head constituents and typically serve to "integrate a content morpheme into a larger constituent” (Myers-Scotton and Jake 2001, pg. 99). Outsider late system morphemes reference information outside of their head constituents and thusly, according to the System Morpheme principle, must come from the ML.

Figure 5: An Example of CS with Each Morpheme Type from the 4-M Model

LLes jeune-s/ [li thagr-o w Sṭa-w-hom $\quad$ b d-dhār]
DEF.PL youth-PL DEM demean.PERF-PL and gave.PERF-PL-3PL.OBJ by DEF-back "The youth who have been demeaned and ignored" ("Sous France")

In Figure 5 above, we can identify every type of morpheme detailed in the 4-M Model. /Jeune/ 'youth', [hagr] 'to demean', [Cṭa] 'to give', and [dhār] 'back' are the content morphemes. The ESMs in this example are the French plural definite article /Les/, the French plural marker $/-s /$, the SAA preposition $[\mathrm{b}]$ 'by', and the SAA definite article, realized as [d], attached to the content morpheme /dhār/ 'back'. The BLSMs are the Arabic demonstrative pronoun [li] and conjunction [w], as they connect phrases together but do not need information outside of their head constituent in order to function. The OLSMs are the morphemes that must reference information outside their head and therefore are predicted to come from the ML. In the example above, the subject-verb 
agreement prefixes [-o] and [-w] are referring to an unnamed actor, while pronoun object [-hom] is referring back to /les jeunes/. As predicted by the MLF and 4-M, the OLSMs come from the ML.

This chapter has given treatments of the sociolinguistic situation of Algeria as well as the phonology, morphology and syntax of SAA. These were followed by a brief explanation of the grammar of French and how French integrates when codeswitched into SAA. A brief discussion of the state of rap music in Algeria was given. Finally, I provided a detailed explanation of codeswitching and how the MLF and 4-M models analyze it. These sections are meant to inform the discussion held in Chapter Four below where I will present the results of my analysis of the data. However, before the discussion of the results, Chapter Three below presents the methodology I followed in order to collect, codify, and analyze the data. 


\section{CHAPTER THREE: METHODOLOGY}

This chapter begins by giving an overall design for this study. The justifications of the data will then be discussed. Finally, the procedures for collection and analysis of the data that I performed will be outlined.

\section{$\underline{\text { Overall Design }}$}

This study provides a description of the intra-CP code switching found in the 2004 Algerian hip-hop album Kobay by contemporary Algerian rap group Double Kanon (commonly referred to as Lotfi $D K$, referring to the name of the rapper in the group, Lotfi Belamri). The lyrics to the 12 songs found on the album served as the data. The data contained CS primarily between SAA and French; however MSA and to a lesser extent English were present as well. Using the principles of the MLF and 4-M models described above, I analyzed the interaction between the grammars of each code in every bilingual sentence. This process yielded information that I used to answer the two research questions of this study:

1. What are the structural patterns of SAA-French codeswitching found in the lyrics of Kobay by Double Kanon?

2. To what extent do the MLF and 4-M models account for these patterns?

\section{Materials}

The lyrics to 11 songs found on the album Kobay served as the data (there is one instrumental song on the album without lyrics). Both of my cultural informants from Eastern Algeria speak the same dialect of SAA that Lotfi raps in. They told me that he is 
famous for his rapping because it is a simple, 'spoken' style that is akin to the common speech of their region. Since I am not a native speaker of any variety of Arabic, I had hoped that his lyrics would contain language that would be relatively easy to comprehend considering the word play and non-standard speech that generally proliferates rap lyrics. Additionally, I chose Lotfi's lyrics because, compared to other popular Algerian rappers such as Fada Vex, Intik and MBS, Lotfi utilizes a high percentage of French vocabulary. I chose the album Kobay because it is a representative album from the height of Lotfi's popularity.

Once I started working with the data, I found that Lotfi's lyrics were anything but simple. Lotfi holds an advanced degree in geology, and his lyrics contain quite a bit of academic vocabulary in both Arabic and French. He uses this elevated vocabulary in tandem with the simple and 'spoken' style that my cultural informants had previously praised him for. His subject matter ranges from immigration to dating to political corruption to organized crime. In fact, the majority of the album was highly politically charged and critical towards traditional power structures (except for religion) in Algeria. According to conversations with my cultural informants, Lotfi's combination of political awareness, specific vocabulary, and lucid delivery make him the most popular rapper in Algeria.

\section{Data collection and coding procedures}

Collecting and coding the data took four steps. First, I received electronic documents containing transcriptions and approximate translations to each song from 
Bouchra. Figure 6 is an example of a line of transcribed lyrics and its translation that Bouchra provided me. She transcribed the Arabic into a version of what is known as the Arabic Chat Alphabet, a way of transliterating Arabic with Roman characters (see Palfreyman \& Al-Khalil 2003).

Figure 6: An Example of the First Step of Data Transcription and Translation (Transcription) W mba3ed la suite, lmektoub sayé ja (Translation) \& Here comes your day!

Second, I examined each transcription while listening to its corresponding song in order to ensure that the transcription represents the performance as accurately as possible. I then verified each Arabic and French word to the best of my abilities in order to create a more linguistically accurate translation. When I could not verify a word with relative certainty, I enclosed it in parentheses and included it in the translation as I did below with (ja). I also edited the French to be as standard as possible. For example, sayé ("that's it"), a colloquial spelling of $c a y$ est, was altered to its standard spelling here. Next, I edited my translations in person with Driss Hanafi in order to catch any glaring errors. Finally, I sent an electronic document for each song to Nawel for further clarification. Figure 7 is an example of the edits Driss and I made to Figure 6 before sending it to Nawel.

Figure 7: An Example of the Second Step of Data Transcription and Translation (Transcription) W mba3ed la suite, lmektoub ça y est ja (Translation) and after the rest, it is written that's it (ja) 
For the third step, Nawel sent me a corrected version of each document I sent her. She corrected any mistranslations of mine and clarified the meanings of words that were unable to be translated by Driss. She also provided clarification on colloquial terms and forms unique to Eastern Algeria. Figure 8 is an example of clarifications that I received from Nawel.

Figure 8: An Example of the Third Step of Data Transcription and Translation (Transcription) W mba3ed la suite, lmektoub ça y est ja (Translation) And then comes the rest, what was written is finally here/came

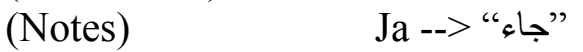

The final step was to select the data I wished to serve as example in this study and code them. I began by rewriting the transcription using the International Phonetic Alphabet. I then identified and examined each morpheme in order to determine its language or language variety it belongs to.

I used typographic conventions in order to provide a visual differentiation between each code (for example: French in italics and English underlined.) I then wrote a gloss translation underneath each transcription. Finally, I revised the translation when needed and put it underneath the gloss. Figure 9 below is how the above piece of data would look like fully coded and ready for analysis.

Figure 9: An Example of the Final Step of Data Transcription and Translation (IPA Transcription) $\quad \mathrm{W}$ mb9ed la swìt l-mektūb $s a \quad j \quad \varepsilon \quad 3 \bar{a}$ : (Gloss) and after DEFFEM rest DEF-written that there is come.PERF.3MSG (Final Translation) "and then the rest, the writing finally came" 


\section{Data analysis procedures}

In order to answer the first research question, I identified each bilingual $\mathrm{CP}$ in the data and then compiled them into a corpus (see Appendix). In order to complete this task, I had to work through some gray areas given the nature of the data. The unit of analysis for codeswitching was traditionally an 'utterance' (i.e. a piece of communication with a pause before and after). For hip hop lyrics, each utterance can be construed to each 'line,' which approximately corresponds with each four beats of the rhythm. However, for this study, the unit of my analysis is the CP. Sometimes in order to find a complete CP, I had to combine data from multiple utterances.

Other times, utterances would consist of 'stranded' NP, PP, and/or AP that could not be analyzed as being a part of any CP. I attempted to not vicariously assign these stranded phrases to neighboring CPs without reasonable cause to do so. I collected a count for these stranded phrases for posterity's sake, but did not include them in the corpus.

Table 28 below summarizes the utterance, CP and stranded phrase counts for each song which contained lyrics on the album. 
Table 28

Counts for Utterances, CPs, and Stranded Phrases

\begin{tabular}{|c|c|c|c|c|c|c|c|c|c|c|c|c|}
\hline Song number: & $\underline{1}$ & $\underline{2}$ & $\underline{3}$ & $\underline{4}$ & $\underline{5}$ & $\underline{6}$ & $\underline{7}$ & $\underline{8}$ & $\underline{9}$ & $\underline{10}$ & $\underline{11}$ & Total \\
\hline Utterances & 24 & 56 & 64 & 68 & 53 & 86 & 44 & 52 & 73 & 52 & 54 & 626 \\
\hline $\mathrm{CPs}$ & 27 & 118 & 113 & 83 & 90 & 138 & 61 & 88 & 120 & 72 & 99 & 1009 \\
\hline SAA ML & 25 & 115 & 108 & 76 & 75 & 131 & 59 & 85 & 119 & 70 & 97 & 960 \\
\hline SAA only & 9 & 74 & 82 & 24 & 38 & 74 & 41 & 68 & 84 & 18 & 85 & 597 \\
\hline W/ French CS & 15 & 41 & 25 & 48 & 37 & 56 & 18 & 17 & 35 & 46 & 12 & 350 \\
\hline W/ English CS & 1 & 0 & 0 & 0 & 0 & 0 & 0 & 0 & 0 & 1 & 0 & 2 \\
\hline W/ Fr. \& Eng. CS & 0 & 0 & 1 & 4 & 0 & 1 & 0 & 0 & 0 & 5 & 0 & 10 \\
\hline French ML & 2 & 3 & 5 & 7 & 15 & 7 & 2 & 3 & 1 & 2 & 2 & 49 \\
\hline W/ SAA CS & 0 & 0 & 0 & 1 & 1 & 0 & 0 & 0 & 0 & 0 & 0 & 2 \\
\hline "Stranded" phrases & 6 & 5 & 8 & 29 & 4 & 18 & 18 & 13 & 12 & 9 & 9 & 131 \\
\hline SAA only & 1 & 4 & 1 & 2 & 0 & 5 & 9 & 7 & 8 & 2 & 4 & 43 \\
\hline French only & 3 & 0 & 1 & 16 & 0 & 5 & 4 & 3 & 0 & 0 & 1 & 33 \\
\hline English only & 0 & 0 & 0 & 0 & 0 & 0 & 0 & 0 & 0 & 1 & 0 & 1 \\
\hline Multilingual & 2 & 1 & 6 & 11 & 4 & 8 & 5 & 3 & 4 & 6 & 4 & 54 \\
\hline
\end{tabular}

After the above process was complete, I categorized each morpheme in each bilingual $\mathrm{CP}$ as one of the four morpheme types identified by the 4-M model: content morphemes, early system morphemes, bridge late-system morphemes and outside latesystem morphemes (Myers-Scotton \& Jake, 2000).

In order to answer research question two, I analyzed each bilingual $\mathrm{CP}$ and determined whether or not it obeyed the principles of the MLF and 4-M models. To do so, I explicitly labeled each CP and every morpheme in accordance to the 4-M model. Next, I determined which language within the bilingual CP was acting as the ML. In order to identify the ML, I had to determine if the data follow the two primary principles of the MLF model. The Morpheme-Order Principle stated the morpheme order of mixed 
constituents will be that of the ML. The System Morpheme Principle dictated that all Outside Late System morphemes must come from the ML. Myers-Scotton (2002) stated that applying these two principles is the best way in which to determine the ML. Once I had determined the ML in this manner, the EL(s) were identified as the language(s) of the morpheme(s) not included in the ML.

Unfortunately, the question of the circular nature of defining the ML still remained. As stated above, there was simply no feasible way of determining the ML with absolute certainty. Therefore, other factors were considered for this study. Since Lotfi DK is a native speaker of SAA and the lyrics of Kobay that do not contain CS are in SAA, it is not surprising that the ML of the majority of data was in fact SAA.

In this chapter I have outlined the basic procedures I followed in collecting, codifying, and analyzing the data used for this study. The data analysis procedures I described resulted in the following chapter which contains the results of this study. 


\section{CHAPTER FOUR: RESULTS}

This chapter seeks to answer this study's two research questions:

1. What are the structural patterns of SAA-French codeswitching found in the lyrics of Kobay by Double Kanon?

2. Can the MLF and 4-M models account for these patterns?

In order to answer these questions, the following section first presents the types of switching found in the data. These examples will include single lexeme switching as well as EL Islands and will be acceptable and easily explainable by the MLF and 4-M models. This section will serve to answer the first research question.

In the next section, I will present and discuss the few examples from the data that are either indeterminate or clearly violate the assumptions of the models. In general, examples of switches that violate the assumptions of the models are rare. This section will conclude with the answer the second research question.

\section{Patterns of 'acceptable' CS}

Of the switches found in the data for this study, the MLF and 4-M models can account for the presence of French content morphemes, specifically nouns, adjectives, adverbs, and verb stems inserted into an SAA frame. The following is a discussion of each one of these 'acceptable' categories of French-SAA CS. For each example, each morpheme, regardless of language, is analyzed as one of the four morpheme categories 
given by the 4-M model: Content Morpheme, Early System Morpheme (ESM), Bridge Late System Morpheme (BLSM), or Outsider Late System Morpheme (OLSM). Then the ML is determined based on the presence of OLSMs and the language variety they are a part of. Each item is presented as a phonetic transcription of the example as rapped. The lexemes of French origin, even if they are heavily Arabized, are in italics. Items in English are underlined.

French nouns

Figure 10: An SAA CP Containing a French Noun

[kājən bhər șīr fī-h trezor kbīr]
there.is sea small in-3M treasure big "There is a small sea with a big treasure" ("Amerika")

Figure 10 above shows an existential SAA sentence containing a French noun [trezor] (French: 'trésor', English: 'treasure'). The French word [trezor] and the SAA words [bhər] ('sea'), [șyīr] ('small'), and [kbīr] ('big') are content morphemes. There are two ESMs in [kājən] ('there is'), and [fī] ('in'). Finally, the third person masculine pronoun [-h] needs to refer to [trezor] in order to find its final form and is therefore an OLSM.

The ML can be analyzed as SAA and the EL as French due to the presence of the SAA third person masculine suffixed pronoun [-h], an OLSM. Another clue that points to SAA being the ML of Figure 10 is the presence of [kājən], which references information outside of its head in order to find its final form. Since [bhər] is masculine and singular, 
[kājon] does not take an OLSM suffix in order to agree; that is, it remains in its masculine singular base form. However, if [bћər] were instead plural ([bћār] 'seas'), [kājən] would take the OLSM [-īn] and become [kājn-īn] in order to agree in number.

French nouns also often appear in the data with an SAA definite article attached. In Figure 11 below, the French singular noun [kozmos] (French: 'cosmos', English: 'cosmos') would normally take the French singular masculine definite article [lə], but instead is preceded by the SAA definite article [1]. This particular SAA definite article is cliticized to the preposition / $\mathrm{min} /$ 'from' (realized here as [mع]) and preceding a masculine French noun.

Figure 11: An SAA CP Containing a French Noun Modified by an SAA Definite Article [kuləS Pãn azmos rāp zāj me-l-kozmos] everything in harmony rap come.PART from-DEF cosmos "Everything is in harmony, rap comes from the cosmos" ("High Technology")

Interestingly, only once in the data did a definite article cliticize to an SAA preposition while preceding a feminine French noun beginning with a consonantal sound (see Figure 24 below). This resulted in an EL Island consisting of the French definite article and the French noun, as in Figure 20 below. Throughout the corpus, the definite article modifying French feminine nouns is normally realized as the French feminine singular definite article [la] and is separate from the SAA preposition.

An ambiguity arises, however, when there is a definite French masculine noun beginning in a vowel sound. While this ambiguity does not have consequences for the models, it is nonetheless an interesting phenomenon. The similarity between the French 
cliticized definite article /l/ and the cliticized SAA definite article /1/ makes their language of origin difficult to pin down. Like French definite articles, those in SAA are cliticized when the initial sound of the content morpheme that it is associated with is a vowel sound. Figure 12 below shows a situation where the language of origin of the definite article is ambiguous.

Figure 12: An SAA CP Containing a French Noun Modified by an Ambiguous Definite Article [Gadīkə 1-Pīstwar mā-n-ąref-ha-S hatə 1-āxər] that.is.why DEF-story NEG-1-know.IMPERF-3FSG.OBJ-NEG until DEF-end "That's why I don't know the story until the end" ("Sous France")

In Figure 12 above, there is a cliticized definite article [1-] connected to the French content morpheme [?īstwar] (French: 'histoire', English: 'story'). Since the definite article in both Arabic and French is cliticized when preceding a word beginning in a vowel sound, the definite article [1] in this example could be either the SAA/1/ or the French $/ l /$, which would make the whole noun phrase an EL Island.

Throughout the data, definite articles are cliticized when preceded by an SAA preposition and are realized as [1]. When preceding a noun that begins with a consonant sound, the origin of the cliticized definite article [1] is clearly SAA, as French definite articles can only be realized this way when preceding words that begin in a vowel sound. When preceding a word that begins with a vowel sound, the cliticized definite article is indeterminate since the realization of the definite article in this context is identical in both languages. 
French adjectives

Figure 13: An SAA CP Containing a French Adjective

[dār-ū șāh fawḍ̂ mental]

do.PERF-3P INTEN chaos mental

"They really made mental chaos"

("Kobay")

Figure 13 above shows a verbal SAA sentence containing a French adjective [mentoel] (French: 'mental', English: 'mental') modifying the Arabic noun [fawḍa]

('chaos'). Note that [fawḍa] is an exception to the gender rule and is masculine noun, and the adjective agrees in gender. The French word [mentcel] and the SAA words [dār] ('to do'), [șāh] ('really, truly'), and [fawḍa] are content morphemes. The third person plural suffix [- $\bar{u}]$ on the SAA verb [dār] is an OLSM, as it looks outside its head to find its form. It refers to an implicit plural subject, understood in the song to be members of the Algerian government.

Since the only OLSM in Figure 13 is from SAA, we can conclude that its ML is SAA.

\section{French adverbs}

Figure 14: An SAA Sentence Containing a French Adverb

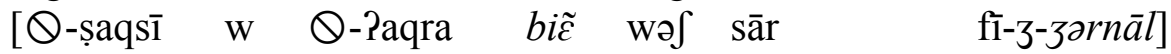

IMP-ask and IMP-read well what happen.PERF in-DEF-newspaper

"Ask and read well what happened in the newspaper"

("Ani Jay")

Figure 14 above is a verbal SAA sentence containing a French adverb [bic̃]

(French: 'bien', English: 'well') modifying the SAA imperative verbs [șaqsī] ('ask') and

[Paqra] ('read'). The SAA words [șaqsī], [Paqra], and [sār] ('to happen') are content 
morphemes, along with the French words $[b i \tilde{\varepsilon}]$ and [zərnāl] ('newspaper'). The SAA preposition [fi] ('in'), the SAA relative pronoun [wəJ] ('what') and the SAA definite article /1/, realized here as [3], are ESMs. The SAA conjunction [w] ('and') is a classic example of a BLSM. The null prefixes attached to $[Q$-șaqsī] and [ $Q$-Paqra] are OLSMs.

There are two CPs in Figure 14. In the first $\mathrm{CP}([Q$-șaqsī w $Q$-Paqra bic̃ $])$, the placement of the French adverb [biẽ ], a content morpheme, conforms to both French and SAA word order; that is, it appears after the verb. We can analyze SAA as the ML because there are SAA words that reference information outside their heads in order to find their form. In this case, the imperative verbs $[\theta$-șaqsī] and $[\theta$-Paqra] both contain a null prefix that indicates that they are second person singular imperative. These prefixes look outside of their head to a hidden agent, the listener, for their final form and are therefore OLSMs.

The most common use of French adverbs in the data are ones that appear extrasententially. Figure 15 below is a typical example of an extra-sentential French adverb used in the data.

Figure 15: A SAA Sentence Containing an Extra-sentential French Adverb

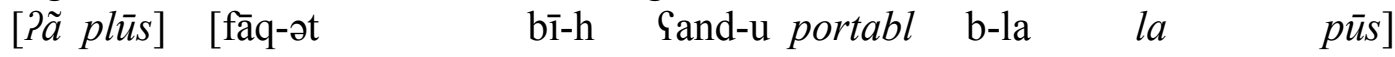
in addition discover.PERF-3F by-3M to-3M cell.phone by-NEG DEF.FEM chip "Additionally, she discovered that he had a cell phone without a SIM card." ("Elm Kbir")

In the above example, the French adverbial phrase [?ã plüs] (French: 'en plus', English: 'additionally') is considered to be above the CP beginning with [fāq-ət] and is therefore extra-sentential. Because of this, there is no grammatical interaction between the adverb and the rest of the sentence. Sentence initial adverbs are often the site of 
codeswitching but cannot play any role in influencing or determining the ML because of their extra-sentential nature.

French verb stems

Below are four examples of French verb stems inserted into SAA frames and taking SAA affixes. Recall from Chapter Two that French verb stems are conjugated as though they are 'finally weak' verbs in Arabic; that is, they have a final vowel that is realized as either [-a] or [-i] depending on the context (see Table 6). Below I discuss examples of French verb stems being conjugated into the perfect and imperfect tenses, the imperative voice, and the present participle form.

The majority of the French verb stems conjugated into SAA found in the data were first conjugation -ER verbs according to French grammar; that is, the non-finite forms of these verb ends with the letters 'er' and with the sound [ēe]. For example, [krasē]

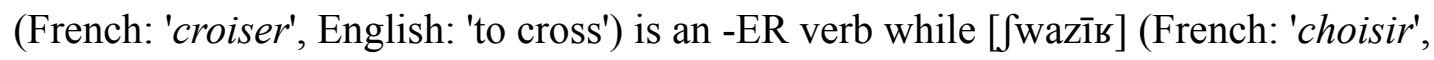
English: 'to choose') is an -IR verb and [vãdьə] (French: 'vendre', English: 'to sell') is an -RE verb. These distinctions are only relevant to French grammar and will not be explored further.

French Verb Stem in the Perfect Tense

Figure 16: An SAA CP Containing a French Verb Stem Conjugated into the SAA Perfect Tense

[krasa-w le mo kīmo skrābəl] cross.PERF-3PL DEF.PL word like Scrabble]

"They crossed the words like Scrabble" ("Amerika") 
Figure 16 above shows the French verb stem [kras-] (from the French verb /croiser/ 'to cross') conjugated into the perfect tense using the SAA third person plural suffix [-w]. The content morphemes in this example are the French verb [krasa], the French noun [mo] ('French: 'mots' English: 'words') and the French noun [skräbəl] ('Scrabble'), which is used in both French and Arabic as the name of this game. The French plural definite article $[l \bar{e}]$ (French: 'les') is an ESM as it is conceptually activated along with, and provides definiteness and plurality to, $[\mathrm{mo}]$; together they make an EL Island. The SAA word [kīmə] ('like, as in') is a BLSM that is integrating the content morpheme [skräbal] into the VP. Finally, the SAA third person plural suffix [-w] is an OLSM because it is referencing information outside its head in order to find its form. There is once again an implied subject here (/les fédéraux/ 'the federal agents') that had been established earlier in the song, similar to Figure 14 and Figure 15 above.

Since the only OLSM in Figure 16 is from SAA, its ML is therefore SAA.

French Verb Stem in the Imperfect Tense

Figure 17: An SAA CP Containing a French Verb Stem Conjugated into the SAA Imperfect Tense [ī-ṣaqsi-w-ək fĩ la pāf zyst jə-provoki-w-ək] 3M-ask.IMPERF-PL-2.OBJ in DEF.FEM PAF just 3M-provoke.IMPERF-PL-2.OBJ "They ask you in the PAF* just to provoke you" *PAF $=$ Police aux frontières ('Border control') ("Sous France")

Figure 17 above shows the French verb stem [provok-] (from the French verb /provoquer/ 'to provoke') conjugated into the imperfect tense using the SAA third 
person masculine prefix [jo-] and the third person plural suffix [-w].

The SAA word [șaqsi] ('ask') and the French word [zYst] ('just, merely'), [provok-] ('to provoke'), and acronym [pāf] ('PAF', 'border control') are content morphemes. The SAA preposition [fĩ] ('in') is an ESM. The French feminine definite article /la/ is also an ESM that is modifying the content morpheme [pāf], and together they make up an EL Island. Finally, each one of the SAA affixes is an OLSM. The segments [ $\left.\overline{1}^{-}\right]$and $[-w]$ indicate that [șaqsi] is in the imperfect plural. The affixes [jə-] and [-w] indicate that [provok-] is in the imperfect plural as well. The subject these OLSMs are referencing in order to find their form is once again implied in this example. (According to the song, there are three candidates that could be performing these actions: /la PAF/, /la police/ ('the police'), or /la douane/ ('customs'). However, each one of those potential subjects is grammatically feminine singular while the two verbs are conjugated into the masculine plural. It can be reasonably inferred that Lotfi DK is referring to the (presumably) majority-male staff of whichever entity is being referred to.) Finally, the SAA second person singular pronoun [-ək], an OLSM referring to the listener, finds its final form from outside its head constituent as well.

Since the OLSMs in Figure 17 are from SAA, we can conclude that its ML is therefore SAA. 
French Verb Stem in the Imperative Voice

Figure 18: An SAA CP Containing a French Verb Stem Conjugated into the SAA Imperative Voice [Q-gardi lo morāl] IMP-maintain DEF.MASC sanity "Maintain your sanity" ("Sous France")

Figure 18 above shows the French verb stem [gard-] (from the French verb /garder/ 'to keep, to maintain') conjugated in the imperative mood. The content morphemes here are the French words [Q-gardi] and [morāl]. The French masculine definite article [lo] is an ESM that is elected along with [morāl]. There are no BLSMs or OLSMs. However, similar to Figure 14 above, the ML can be analyzed as SAA due to the presence of the SAA null prefix, which looks outside its head for its referent, on the imperative verb [Q-gardi].

French Verb Stem as a Present Participle

Figure 19: An SAA CP Containing a French Verb Stem Conjugated into an SAA Participle [rājəh lhīk ā-k fərhān w mə-tras-i] going.PARTIC there PROG-2SG happy and PARTIC-plan-3MSG "You're going there happy and planning" ("Sous France")

Figure 19 above shows the French verb stem [tras-] (from the French verb /tracer/, 'to draw, to plan') conjugated into a present participle using the SAA prefix [mo-]. There are two CPs in this example. The second one, beginning in [a-k], is the focus of the following analysis. The SAA adjective [fərhān] and the French verb stem 
[tras] are content morphemes. The SAA participle prefix [mə-] and the SAA progressive marker [ā-] (a reduction of [rā]) are both ESMs. The SAA conjunction [w] is a BLSM. Finally, the SAA second person object pronoun $[-\mathrm{k}]$ and the SAA masculine singular participle suffix [-i] are OLSMs. Due to the presence of the SAA OLSMs, we can analyze the ML of Figure 19 as SAA.

\section{$\underline{\text { EL Islands }}$}

As explained in Chapter Two, EL Islands involve two or more EL constituents that show internal dependency contained within an otherwise ML frame. In the data for this study, there were multiple kinds of French EL Islands found. Below, I present the most common instances of EL Islands from the data: a definite article preceding a noun, an adjective preceding a noun, two nouns joined by a BLSM, and a prepositional phrase.

\section{Definite Article Preceding a Noun}

Figure 20: An SAA CP Containing a French EL Island Consisting of a Definite Article Preceding a Noun

[fì la $\quad v w a$ Pā-n̄̄ $\quad$ Sagūn]

in DEF.FEM voice PROG-1SG mute

"In the voice I am mute"

("C'est Magique")

Figure 20 above shows an EL Island consisting of the French feminine singular article $[l a]$ and the French noun $[v w a]$ (French: 'voix', English: 'voice'). The French definite article is dependent upon the feminine noun /voix/ in order to find its final form. The EL Island is incorporated into the larger CP. The CP also contains the SAA content 
morpheme [Gagūn] ('mute'), the SAA ESMs [fī] ('in') and the progressive marker [ā] (a reduction of [rā]), and the SAA OLSM [nī], which looks outside its head for its final form. Due to the presence of an SAA OLSM, we can analyze the ML of this CP as being SAA.

In the data for this study, EL Islands consisting of a French definite article and a French noun were feminine constructions the majority of the time. Nowhere in the data did I find a masculine French noun modified by the French masculine definite article /le/. Masculine French nouns with a definite article took the SAA definite article the majority of the time (see Figure 11 above).

\section{Adjective Preceding a Noun}

Figure 21: An SAA CP Containing Adjective-Noun French and English EL Island Constructions

[had Jicr ?'ōt gam haj teknōlozi]

DEM poetry high range high technology

"This poetry is high class, high technology." ("High Technology")

Figure 21 above shows two EL Islands, each consisting of a noun-adjective construction. Neither of these word pairs follows the SAA noun-adjective word order rules, instead following those of their language of origin, and are therefore EL Islands. The first EL Island is /haute gamme/ ('high class'). Here, the French word [ōt] (French: 'haute', English: 'high, great') is modifying [gam] (French: 'gamme', English: 'scale, range') according to French morphosyntactic word order. The same situation occurs with the English EL Island/high technology/. Here, the English word/high/ modifies /technology/ according to English morphosyntax. 
The CP that contains these two EL Islands also contains the SAA content

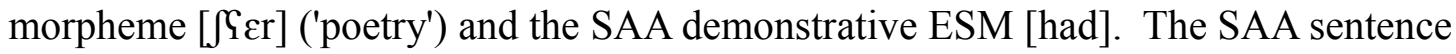
under the $\mathrm{CP}$ is an equational sentence in the imperfect tense. Since subject is definite, the predicate is indefinite, and there is no overt verb, there is an implied present tense copula 'is' between the subject and the predicate. Despite the absence of any SAA OLSMs, the ML of the CP can still be analyzed as SAA due to the presence of SAA syntax.

Two Nouns Joined by a BLSM

Figure 22: An SAA CP Containing a French EL Island Consisting of Two Nouns Joined by a BLSM

[der-t la fyzõ bə-1-monoksīd do karbõ] do.PERF-1SG DEF.FEM fusion by-DEF-monoxide GEN carbon "I made a fusion with carbon monoxide" ("Intro")

Figure 22 above shows an EL Island consisting of the French nouns [mənoksīd] (French: 'monoxyde', English: 'monoxide') and [karbõ] (French: 'carbone', English: 'carbon') exhibiting dependency via the French genitive particle /de/, a BLSM. This EL Island is in a CP that also contains the EL Island /la fusion/ along with a number of SAA morphemes. The SAA verb [der] ('to do') is a content morpheme. The SAA preposition [bə-] ('by, with') and definite article [1] are ESMs. The SAA first person singular suffix [t] is an OLSM; due to its presence, the ML of the CP can be analyzed as SAA. 
McLain-Jespersen 74

Prepositional Phrase

Figure 23: An SAA CP Containing a French EL Island Consisting of a Prepositional Phrase

[bdī-t rāp par hazārd]

begin.PERF-1SG rap by accident

"I started rap by accident"

("C'est Magique")

Figure 23 above shows an EL Island consisting of the French preposition [par] (French: 'par', English: 'by') and the noun [hazārd] (French: 'hazard', English: 'accident'), the object of the preposition. The CP in this example also contains the SAA content morpheme [bdī] ('begin') and the French $[r \overline{a p}]$ ('rap'), as well as the SAA OLSM [-t], the first person singular suffix. The presence of the SAA OLSM indicates that the ML of this CP is SAA.

It should be noted that the data include a number of prepositional phrases as EL Islands and that they are most often French set expressions (such as /par hasard/ 'by accident' and /en l'air/'floating') and therefore resist separation of their elements, a fact that encourages their use as EL Islands. Interestingly, these set expressions show more phonological integration into SAA than their EL Island counterparts, which Lotfi tends to pronounce in a fashion closer to that of standard French. For example, Lotfi includes the SAA rolled [r] and pronounces the ' $h$ ' at the beginning of the word /hasard/ while the French expression /par hasard/ is realized approximately as [рав ?аzaьd] in standard French. Similarly, Lotfi raps the French expression /en l'air/ ([ã laь $]$ in standard French) as [an lēr], using the SAA rolled [r], replacing the nasal vowel [ã ] with one acceptable in SAA [a], and pronouncing the ' $n$ ' in the word 'en'. 
This section has shown the patterns of acceptable codeswitching between French and SAA. I began by explicating ten representative examples of single lexeme switching between French and SAA. Through these examples, we saw the ways in which French nouns, adjectives, adverbs and verbs are codeswitched into SAA. Furthermore, by analyzing each morpheme via the 4-M model, I have shown that these examples fall within the parameters of the MLF model. The CS results were followed by four examples of French EL Islands contained with SAA CPs. These examples were representative of the types of EL Islands found in the data and did not diverge from the parameters set by the MLF model. The explication of all of these CS patterns serve as the answer to Research Question 1.

\section{$\underline{\text { Potentially Problematic Codeswitching Data }}$}

The following section details three patterns from the data that the MLF and 4-M models cannot fully account for. First, I will present an instance of definite articles from both SAA and French modifying the same French content morpheme. Next, I go on to detail the unexpected behavior of the French adverb 'jaimas'. Finally, I will show two examples of ambiguous conjugation on French verb stems. This section will conclude with a discussion on the answer to Research Question 2.

\section{Doubled Definite Articles}

In Figure 24 below, there are two sets of doubled definite articles, each modifying an instance of the French content morpheme [pūsjer] (French: 'poussière', English: 'dust'). 
There are two instances of the same EL Island [la püsjer] in this sentence. The first EL Island is preceded by [me-1], the SAA definite article cliticized onto the SAA preposition [min]. The second EL Island is preceded by [1<-1], the SAA definite article cliticized onto the SAA preposition [li1]. In each case, there is an audible pause between the SAA definite article and the French one. Figure 24 is the only instance of doubled definite articles found in the data.

Figure 24: An SAA CP Containing a French Noun Modified by both French and SAA Definite Articles [kīmə gāl 1-masī̄ī-n me-1 la pūsjer le-1 la $\quad$ püsjer] like say.PERF DEF-Christian-PL from-DEF DEF.FEM dust to-DEF DEF.FEM dust "Like the Christians said, from dust to dust." (“Ani Jay")

This instance may be similar to the 'double morphology' phenomenon as discussed by Myers-Scotton (1993, pg. 135). In cases of double morphology, a speaker may utter a content morpheme marked with plural markers from both the ML and EL, for example. Myers-Scotton attributed this behavior to a misfiring of the language production process. However, the data for this study is not naturally spoken language, but crafted poetry. Any mistakes made by the language production process could therefore theoretically be corrected.

One possible explanation for this case is that this is an example of what Poplack (2004) termed 'flagged switching.' According to Poplack, flagged switching can be marked by metalinguistic commentary in the switch itself - that is, an explicit comment or a pause - as opposed to 'smooth switching,' which refers to the kinds of switching discussed in the previous section where there is no hesitation or pause at switch points. 
In this case, it is possible that the metalinguistic commentary indicating the flagged switch are the elements of the French saying 'de la poussière à la poussière' ('from dust to dust'), somewhat of a set phrase used in particular situations such as funerals, resisting total separation from one another.

\section{The French Adverb 'Jamais'}

There are three separate examples of the French adverb of negation [zəme] (French: 'jamais', English: 'ever, never') used in the data. Below I illustrate one of the occurrences as its structure is demonstrative of the other instances that occur in the data. The following section illustrates how the way Lotfi, and likely Algerians generally, uses /jamais/ runs counter to the assumptions of the MLF and 4-M models.

The closest SAA equivalent to /jamais/ is [९əmr] 'lifespan, age,' a noun which is followed by a proper name (e.g., 'Mahjouba's age') or a possessive suffix (e.g., 'her life') co-indexed with subject markers on a verb or a noun in the sentence. It also occurs immediately before the verb over which it has scope. As is illustrated in Figure 26 below, when [९əmr] is used to mean 'never', it co-occurs with the corresponding negative particle [mā]. Together, these elements mean 'I/you/he/she/we/they never'. Significantly, the negative suffix $\left[-\int\right]$ never appears when [९əmr] 'never' is present, an indication that [९əmr] is a negative polarity item.

It is important to note that in French, /jamais/ can be used to mean 'ever' or 'never,' depending on the context. It means 'ever' in affirmative statements and questions while in negative statements it means 'never.' When used to mean 'never,' /jamais/, like [Cəmr] in 
SAA, occurs with a negative particle, in this case /ne/.

However, when /jamais/ is switched into SAA, an unexpected structure results.

Figutre 25 below shows /jamais/ being used to negate an SAA verb while Figure 26

shows the same sentence as Figure 25, but constructed with [โəmr] in place of /jamais/ in order to illustrate the difference between the structures.

Figure 25: An SAA CP Containing an SAA Verb Modified by the French Adverb /jamais/

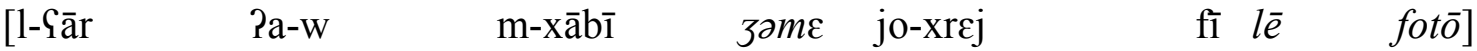
DEF-scandal PROG-3MSG PART-hidden never 3PL-exit.IMPERF in DEF.PL photo "The scandal is hidden, it never comes out in the photos" (“Ani Jay”)

Figure 26: An SAA CP Containing an SAA Verb Modified by the SAA [Səmr] and [mā]

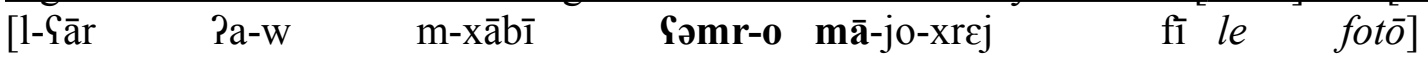
DEF-scandal PROG-3MSG PARTIC-hidden age-3SG NEG-3PL-exit.IMPERF in DEF.PL photo "The scandal is hidden, it never comes out in the photos"

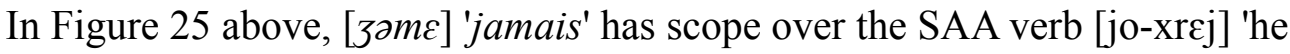
exits'. This instance of /jamais/, like the other two in the data, appears where we would expect [९əmr] to appear in SAA; it is a single lexeme switch and therefore should fit into the SAA word order rules, according to Myers-Scotton's predictions. However, there is a structural asymmetry between the usage of these two lexemes that cannot be accounted for by the MLF and 4-M models. In the data, when used in SAA, /jamais/ does not pattern like [โəmr], as the former co-occurs with neither a pronoun suffix nor a negative particle. The absence of the pronoun suffix may or may not be an issue of morphosyntax as the suffix could be analyzed as a unique lexical item associated with [९əmr]. 
The absence of the negative particle, however, presents an irreconcilable problem for Myers-Scotton's models in that /jamais/ patterns neither with SAA nor French in this regard. Indeed, with the absence of a negative particle, /jamais/ is alone in carrying the sense of 'never.' It is worth mentioning that Nawel Krarzia, my main cultural informant, wrote in an e-mail that /jamais/ is used without a negative particle in SAA.

One possible contributing factor for this behavior is the unique sociolinguistic situation between French and SAA which may have resulted in an unpredicted semantic change in the borrowing of /jamais/. Another possible explanation is that this usage of /jamais/ is restricted to Lotfi's constructed lyrical data. What is clear is that further analysis is needed of the semantics and morphosyntax of /jamais/ when used in SAA, whether as a switch or a borrowed form. Unfortunately, this issue is beyond the scope of this project.

\section{Ambiguous Conjugations of French Verbs}

Figure 27 and Figure 28 below contain two instances of French verb stems conjugated into SAA that resulted in ambiguous forms. Lotfi's pronunciation of the French verb stem conjugated into SAA does not correspond with the phonological rules for SAA finally weak verbs. As such, it is indeterminate which form these French verb stems are taking and why. 
Figure 27: Example 1 of an SAA Sentence Containing an Ambiguously Conjugated French Verb Stem

\begin{tabular}{lllll}
\hline [mālə jīb l-üranìm & $n$-separē & $l \varepsilon z$ & atəm]
\end{tabular}

so bring.IMP DEF-uranium 1SG-separate.IMPF DEF.PL atom

"So bring the uranium, I'll separate the atoms"

("Kobay")

Figure 28: Example 2 of an SAA Sentence Containing an Ambiguously Conjugated French Verb Stem

[wə n-Yāwən ma patrī wa n-finãse $\bar{e} d \bar{e}$ partī] and 1SG-help.IMPF 1SG.POS country and 1SG-finance.IMPF INDEF.PL political.party "And I'd help my country and I'd finance some political parties" ("Kobay")

In Figure 27, the item [n-scparē] appears to be the French verb stem [scpar-] (from the French non-finite verb 'séparer', English: 'to separate') conjugated into the first person imperfect tense using the SAA prefix [n-]. Similarly, in Figure 28, the item [nfinãsē] appears to be the French verb stem [finãs-] (from the French non-finite verb 'financer', English: 'to finance, to fund') conjugated into the first person imperfect tense using the SAA prefix [n-].

The [-ē] vowel ending is a common one used in French morphology. Most notably, it is used with -ER verbs in the 'infinitif' ('non-finite') form. Recall from Chapter Two that French verb stems are treated as though they are SAA finally weak verbs and therefore must end in either the vowel sound [-1] or [-a], depending on tense. According to SAA morphosyntax, these two French verb stems must end with [-1̄], agreeing with the singular imperfect tense. However, in both of these instances, the French verb stem ends in the vowel sound [-ē]. These items cannot be analyzed as having French '-er' endings without running contrary to the MLF and 4-M models. 
It is worth mentioning that my primary cultural informant Nawel Krarzia stated that she heard these two instances as [n-scpar-1] and [n-finãs-î], which would follow the SAA conjugation rules perfectly. As I demonstrated in Chapter Two above, SAA does not contain the vowel [e]. Therefore, Nawel hearing [-i] could potentially be due to an issue of perception in that she is less likely to hear a vowel sound that is not in her native language. Usually, I would defer to her opinion in my analysis; however, the vowels that end these two words are undeniably $[-\bar{e}]$. Whether this unusual pronunciation is due to linguistic, artistic or other factors is indeterminable.

The above section has shown that within the data, there were examples of switching that were difficult to account for using the 4-M and MLF models alone. Therefore, the tentative answer to Research Question 2 is that the MLF and 4-M models cannot account for all of the data. This issue will be explored in Chapter Five below. 


\section{CHAPTER FIVE: CONCLUSION}

The first section of this chapter presents answers to the two research questions by discussing the principle findings of this study. The relevance of the results of this study to the literature of codeswitching, hip hop, and globalization studies is detailed in the second section. The third section summarizes the limitations of the study. Finally, the fourth section provides suggestions for further research.

\section{$\underline{\text { Research questions }}$}

1. What are the structural patterns of SAA-French codeswitching found in the lyrics of Kobay by Double Kanon?

In Chapter Four above I detailed the ways in which French lexemes are codeswitched into SAA. The examples and their explanations presented in the first section of Chapter Four serve as the answer to the first research question. I will briefly summarize them below.

In the data we find two types of switching between French and SAA: mixed constituents and EL Islands. Recall from Chapter Two above that a mixed constituent is a single EL lexeme inserted into an ML frame. In Chapter Four, I demonstrated that French nouns, adjectives, adverbs and verb stems appeared in the data in mixed constituents inserted into SAA frames. French lexemes also appeared in the data in the form of EL Islands. EL Islands are constituents made up of more than one EL morpheme that show dependency with one another according to the EL grammar. I gave four 
examples of the patterns of EL Islands found in the data, namely article-noun constructions, nouns modified by adjectives, two nouns connected by a BLSM, and prepositional phrases.

The explanation for each of these examples classified each morpheme according to the 4-M model. I then analyzed the ML of each $\mathrm{CP}$ in each example in order to determine whether or not the switching corresponded with the assumptions of the MLF and 4-M models. This leads us to the answer for Research Question 2.

2. Can the MLF and 4-M models account for these patterns?

In the explanations for each example in Chapter Two, I attempted to determine the ML of each bilingual CP. I checked the morphosyntax of each morpheme against the Morpheme-Order Principle and the System Morpheme Principal and found that in the vast majority of cases, the MLF and 4-M models accounted for the patterns of codeswitching in the data.

There were three categories of examples found in the data that cannot be elucidated fully by analyzing them via the MLF and 4-M models alone. These categories were doubled definite articles, the use of jamais, and indeterminate French verb stem conjugation. Of these three categories, it is the penultimate that was most difficult the MLF and 4-M models. The structural asymmetry between the use of jamais and [Səmr] in SAA is a heretofore unsolved issue in the English language codeswitching literature. 


\section{Contributions of this study}

This study contributes to at least two fields of research. First, it provides a unique set of data to analyze using the MLF and 4-M models. To the author's knowledge, this is the first instance of a data set comprised of rap lyrics being structurally evaluated using Myers-Scotton's models. Previous research on codeswitching in rap lyrics focused mainly on the social function of CS instead of the structural constraints of the data. The analysis of rap lyrics in a structural context provides a unique opportunity to test the robustness of Myers-Scotton's models as well as shed valuable insight into this important musical genre using empirical evidence.

Finally, the patterns presented in the data informs the research on the sociolinguistic situation of North Africa, especially considering the influence that musicians have on society. The overtly political messages contained in the lyrics and how they are expressed linguistically are of interest to anyone wishing to understand the discourse of rap music in Algeria and other forms of youth media. These subjects can be seen of great importance in Algeria and all of the Middle East, as the youth demographic is large and becoming increasingly influential, especially after the Arab Spring. Indeed, $46 \%$ of Algeria's population is under the age of 25 (Central Intelligence Agency, 2013). This study contributes to the understanding of the language and discourse of this demographic.

Finally, this study contributes to the field of globalization studies, specifically the globalization of both language and music. The corpus for this study contains French items which are both historic and recent and it demonstrates their varied integration into 
SAA. Musically, this study should be of interest to researchers interested in the spread of hip hop around the world and the form it takes in specific contexts. In the Algerian context, many hip hop artists use it to express political dissent that they otherwise did not have a venue for previously. This study gives further insight into the form that this dissent might take.

\section{$\underline{\text { Limitations }}$}

This study's major limitation was that I am neither a native speaker of SAA nor French. This proved to be a major hindrance during the transcription and initial analysis of my data. This limitation was a contributing factor to another limitation of this study: its small sample size. Ideally, I would have liked to look at a broader spectrum of North African rap lyrics or even other forms of constructed communication, however the amount of effort that proved necessary to transcribe, translate and analyze just one album was substantial. Obviously, the conclusions I drew would have been better informed given a larger sample size.

However, the small sample size had a certain advantage insofar as it was very much like a case study. While I believe a more exhaustive look at CS data within North African hip hop lyrics is needed, this study's value was in the depth that it explored Lotfi's lyrics. This allowed me to find the patterns of codeswitching more readily and more easy come to my conclusions. Finally, this study serves as an example of a self contained unit of discourse containing codeswitching, and hopefully can inspire further studies in this field. 


\section{Opportunities for further research}

There are several opportunities for further research that stem from this study.

The most obvious area in need of investigation is the use of the French adverb jamais in SAA. The data from this study suggests that there are undocumented behaviors in the morphosyntax and/or semantics of jamais when used in SAA. Whether there are influences from natural changes due to the historical nature of French/SAA contact or simply from the artistic nature of the data needs further explication.

A second major issue for this study is the poetic nature of the data. Rap lyrics such as these are precisely crafted and such linguistic behaviors such as codeswitching are often used for rhetorical purposes. Davies and Bentahila (2008) wrote:

Code-switching, in addition to being a useful resource for the bilingual in everyday interaction with other bilinguals, may also serve a poetic function, contributing to the aesthetic and rhetorical effects of discourse that is not spontaneous, but carefully constructed. (2)

Since the MLF and 4-M models were created with spontaneous codeswitching in mind, I believe that constructed instances of codeswitching present significant difficulties to these models. This is especially applicable to codeswitching found in rap lyrics because poetic aspects of meter, rhyme, and wordplay constantly affect word choice. However, we can expect rap lyrics and other verbal art to bend the rules in predictable ways. Therefore, it should not be beyond possibility to incorporate patterns of codeswitching in verbal art and other forms of constructed communication to the already robust MLF and 4-M models. 
Finally, as mentioned in the limitations section above, this study was limited to the lyrics of one album by one artist. Being able to do a similar study with data that spanned across different axes would yield much more compelling evidence. For example, rap has been present in all of North Africa since the late 1980s. Hundreds of artists have released albums and many of them have reaches critical acclaim in North Africa and abroad. These albums have contained lyrics in SAA, MSA, French, Spanish, Italian, English and Tamazight. There are many different variables to explore when researching the cross-roads of language, hip hop and globalization. 
McLain-Jespersen 88

\section{REFERENCES}

al Arousni, L. (2007, June 21). Morocco's hip hop revolution. Asharq Alawsat. Retrieved November 21, 2010, from http://www.asharq-e.com.

Alim, H.S. (2002). Street-conscious copula variation in the hip hop nation. American Speech, 77 (3), 288-304.

Alim, H.S. (2003). On some serious next millennium rap ishhh: Pharoahe Monch, hip hop poetics, and internal rhymes of internal affairs. Journal of English Linguistics, 31 (1), 60-84.

Ambah, F.S. (2008, February 22). Saudi hip-hop's painful birth. The Washington Post. Retrieved November 21, 2010, from http://www.washingtonpost.com.

Belhaj, I. (2007, August 06). Young Moroccans dance to hip hop beats. Magharebia. Retrieved November 21, 2010, from http://www.magharebia.com.

Bergman, E.M. (2005). Spoken Algerian Arabic. Springfield: Dunwoody Press.

Bouhadiba, F. (1988). Aspects of Algerian Arabic verb phonology and morphology. (Doctoral Dissertation.) University of Reading.

Boumans, L. (1998). The syntax of codeswitching: Analysing Moroccan Arabic/Dutch conversations. Tillburg: Tillburg University Press.

Bradley, A. (2009). Book of rhymes: The poetics of hip hop. New York: Basic Civitas Books.

Central Intelligence Agency. (2013, November 08). The world factbook: Algeria. Retrieved from https://www.cia.gov/library/publications/the-worldfactbook/geos/ag.html\#People.

Clarke, S., \& Hiscock, P. (2009). Hip-hop in a post-insular community: Hybridity, local language, and authenticity in an online Newfoundland rap group. Journal of English Linguistics, 37 (3), 241-261.

Cutler, C. (2010). Hip-hop, white immigrant youth, and African American vernacular English: Accommodation as an identity choice. Journal of English Linguistics, 38 (3), 248-269.

Daoudi, B. (2000, July/August). Algerian rappers sing the blues. The UNESCO Courier, $53,34-35$. 
Daragahi, B., \& Fleishman, J. (2009, April 07). Mideast rappers take the mic. Los Angeles Times. Retrieved November 21, 2010, from http://www.latimes.com.

Davies, E.E., \& Bentahila, A. (2006). Code switching and the globalisation of popular music: The case of North African rai and rap. Multilingua, 25, 367-392.

Davies, E.E., \& Bentahila, A. (2008). Code switching as a poetic device: Examples from rai lyrics. Language \& Communication, 28, 1-20.

Ennaji, M. (1991). Aspects of multilingualism in the Maghreb. International Journal of the Sociology of Language, 87. 7-25.

Fariborz, A. (2006, March 01). Rap rebellion - loud and proud. Qantara. Retrieved November 21, 2010, from http://www.qantara.de/webcom/show_article.php/_c310/ nr-249/i.html

Fenn, J., \& Perullo, A. (2000). Language choice and hip hop in Tanzania and Malawi. Popular Music and Society, 24 (3), 73-93.

Ferguson, Charles A. 1959. Diglossia. Word 15, 325-340.

Gardner-Chloros, P. (2009). Code-switching. New York: Cambridge University Press.

Garrett, M.F. (1976). Syntactic process in sentence production. In R.J. Wales, \& E. Walker (Eds.), New approaches to language mechanisms. (pp. 231-256). Amsterdam: North Holland.

Geider, T. (2005). Code-switching between Swahili and English in East African popular literature: David Maillu's Without Kiinua Mgongo and other cases. Matatu, 31, 115-131.

Heller, M. (Ed.). (1988). Codeswitching: Anthropological and sociolinguistic perspectives. Berlin: Mouton De Gruyter.

Joshi, A. (1985). Processing of sentences with intrasentential codeswitching. In D. R. Dowty, L. Karttunen, \& A. Zwicky (Eds.), Natural language parsing (pp. 190205). Cambridge, U.K.: Cambridge University Press.

Joshi, M. (2009, June 13). Hip-hop rocks Iraqi youth in “boogie-down” Baghdad. TopNews. Retrieved November 21, 2010, from http://www.topnews.in.

Kagda, F., \& Abdul Latif, Z. (2009). Cultures of the world: Algeria. New York: Marshall Cavendish. 
Kahf, U. (2007). Arabic hip hop: Claims of authenticity and identity of a new genre. Journal of Popular Music Studies, 19 (4), 359-285.

Keddad, S. (1986). An analysis of French-Arabic codeswitching in Algiers. (Doctoral Dissertation). University of London.

Keeler, W. (2009). What's Burmese about Burmese rap? Why some expressive forms go global. American Ethnologist, 36 (1), 2-19.

Lebouachera, M. (2009, July 17). Iraqi rappers use music to air out hopes and fears. The Jakarta Globe. Retrieved November 21, 2010, from http://www.thejakartaglobe.com.

Low, B.E. (2007). Hip-hop, language, and difference: The n-word as a pedagogical limitcase. Journal of Language, Identity, and Education, 6 (2), 147-160.

Magnusson, M. (2008). "Not perfect grammar, always perfect timing": African American vernacular English in black and white rap lyrics. (Doctoral Dissertation). Karlstad University.

Mendieta-Lombardo, E., \& Cintron, Z.A. (1995). Marked and unmarked choices of code switching in bilingual poetry. Hispania, 78 (3), 565-572.

Muysken, P. (2000). Bilingual speech: A typology of code-mixing. Cambridge: Cambridge University Press.

Myers-Scotton, C. (1992). Comparing codeswitching and borrowing. In C. Eastman (Ed.), Codeswitching (pp. 19-39). Clevedon: Multilingual Matters.

Myers-Scotton, C. (1993). Duelling languages. Oxford: Claredon Press.

Myers-Scotton, C. (1993b). Social motivations for codeswitching. Oxford: Claredon Press.

Myers-Scotton, C. (Ed.) (1998). Codes and consequences: Choosing linguistic varieties. New York: Oxford University Press.

Myers-Scotton, C. (2002). Contact linguistics: Bilingual encounters and grammatical outcomes. Oxford: Claredon Press.

Myers-Scotton, C. and Jake, J. (1995) Matching lemmas in a bilingual language competence and production model: Evidence from intrasentential codeswitching. Linguistics 33, 981-1024. 
Myers-Scotton, C., \& Jake, J. (2000). Testing the 4-M model: An introduction. The International Journal of Bilingualism, 4 (1), 1-8.

Myers-Scotton, C., \& Jake, J. (2001). Explaining aspects of code-switching and their implications. In J. Nicole (Ed.), One mind, two languages: Bilingual language processing. (pp. 84-116). Malden: Blackwell Publishers.

Paine, S. (2012). The quadrilingual vocabulary of French rap. Multilingualism in Popular Arts, 3 (1), 48-69.

Palfreyman, D., \& al-Khalil, M. (2003). "A funky language for teenzz to use": Representing Gulf Arabic in instant messaging. Journal of Computer Mediated Communication, 9 (1), http://jcmc.indiana.edu/vol9/issue1/palfreyman.html, retrieved May 28, 2013.

Poplack, S. (2004). Code-switching. In U. Ammon, N. Dittmar, K. J. Mattheier \& P. Trudgill (Eds.), Soziolinguistik: an international handbook of the science of language (pp. 589-596). Berlin: Walter de Gruyter.

Poplack, S., \& Sankoff, D. (1984). Borrowing: The synchrony of integration. Linguistics, 22. 99-135.

Poplack, S., \& Sankoff, D. (1988). Code-switching. In U. Ammon, N. Dittmar \& K. Mattheier (Eds.), Sociolinguistics: An international handbook of the science of language and society (Vol. 2, pp. 1174-1180). Berlin: Walter De Gruyter.

Price, C., Green, D., \& von Studnitz, R. (1999). A functional imaging study of translation and language switching. Brain, 122, 2221-2235.

Sankoff, D., \& Poplack, S. (1981). A formal grammar for code-switching. Papers in Linguistics 14 (1-4), 3-45.

Sarkar, M., \& Winer, L. (2005). Multilingual codeswitching in Quebec Rap: Poetry, pragmatics and performativity. International Journal of Multilingualism, 3 (3), 173-192.

Smitherman, G. (1997). "The chain remain the same": Communicative practices in the hip hop nation. Journal of Black Studies, 28 (1), 3-25.

Souag, M.L. (2006). Explorations in the syntactic cartography of Algerian Arabic. (Master's Thesis.) University of London. 
Warren, A., \& Evitt, R. (2010). Indigenous hip-hop: Overcoming marginality, encountering constraints. Australian Geographer, 41 (1), 141-158.

Woolard, K. A. (1988). Codeswitching and comedy in Catalonia. In M. Heller (Ed.), Codeswitching: Anthropological and sociolinguistic perspectives (pp. 53-76). Berlin: Mouton De Gruyter. 


\section{APPENDIX: CPS CONTAINING CODESWITCHING}

\section{INTRO}

1. [naSto-1-hom

la $\quad$ pusãs $^{1}$ təS lə-ћdīd-a]

describe.PERF-to-3PL.OBJ DEF.FEM power GEN DEF-iron-FEM

"He described to them the power of iron"

2. $[\mathrm{k} \overline{1} \quad$ fhom-t

lo $\quad$ prensip $\left.^{2}\right]$

when understand.PERF-1SG DEF.MASC principle

"When I understood the principle"

3. [3Ib-t

bring.PERF-1SG

le parol $\left.^{3}\right]$

"I brought the words"

DEF.PL word

4. [dər-t la fuso $\tilde{O}^{4}$ bI-1 monoksīd do karbon ${ }^{5}$ ] do.PERF-1SG DEF.FEM fusion by-DEF monoxide GEN carbon

"I made a fusion with carbon monoxide"

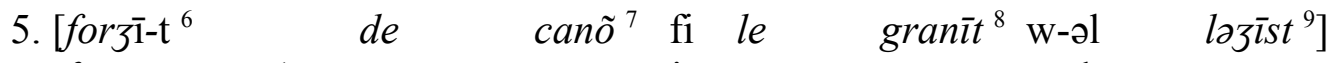
forge.PERF-1sg INDEF.PL cannon in DEF.PL granite and-DEF jurist "I forged some cannons from rocks and a jurist"

6. [wolī-t Parfimed $\left.{ }^{10}\right]$

become.PERF-1SG Archimedes

"I became Archimedes"

7. [Q-Sajit-1-1- $\quad$ l-alfimist ${ }^{11}$ ]

IMP-call-to-1SG.OBJ DEF-alchemist

"Call me the alchemist"

8. [n-dIfn-ū kimo la muraI do $\operatorname{fin}^{13}$

1SG-inagurate.IMPF-3M.OBJ like DEF.FEM wall GEN China

"I'll inaugurate it like the wall of China"

wla la Palpīn ${ }^{14}$ bi le fwit do niogara ${ }^{15}$ or DEF.FEM mountain.PL alpine by DEF.PL waterfall GEN Niagara

"Or the Alps in Niagara Falls"

$\mathrm{k} \int$ yol le rof $d u r^{16}$ tạ zbil țōra bōra]

like DEF.PL rock hard GEN mountain.PL Tora Bora

"Like the hard rocks of the Tora Bora mountains" 


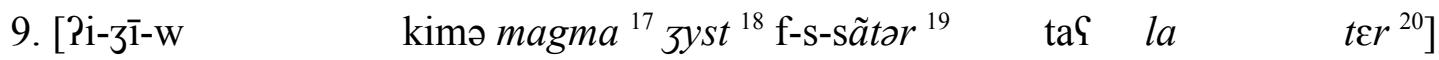
3M-come.IMPF-PL like magma just in-DEF-center GEN DEF.FEM earth "They come just like the magma in the center of the earth"

10. [wejn kejn la falü ${ }^{21}$ ]

where exist.PERF DEF.FEM heat

"Where there is heat"

11. [?ənā l-alpinist $\left.{ }^{22}\right]$

1SG.PRO DEF-mountaineer

"I am the mountaineer"

12. [le pist ${ }^{23}$ humə le kов $\left.^{24}\right]$

DEF.PL track 3PL.PRO DEF.PL rope

"The tracks are the ropes"

13. [lez akов ${ }^{25}$ wəla-w de ков $\left.^{26}\right]$

DEF.PL chord become.PERF-3PL INDEF.PL body

"The chords became some bodies"

14. [le parol $^{27}$ las9-in fi-1 kos $\left.^{28}\right]$

DEF.PL lyric stuck-PL in-DEF body

"The lyrics are stuck in the body"

15. [?aI kəm $^{29}$ gal-ū-1-i]

and as say.PERF-3PL-to-1SG.OBJ

"And as they said to me"

16. [n-mūt kīmə blandi ${ }^{30}$ wəla marten lūter $\quad$ kīn ${ }^{31}$ ] 1SG-die.IMPF like Blondie or Martin Luther King "I die like Blondie or Martin Luther King"

17. [wali-t-Il-hom kafmas $^{32}$ ] become.PERF-1SG-to-3PL.OBJ nightmare

"I became a nightmare to them."

18. [le kaset ${ }^{33}$ nəb९a-t-hom fì-hom șawt-1̄ $\quad \mathrm{w}$ təswīra] DEF.PL cassette send.PERF-1SG-3PL.OBJ in-3PL.OBJ voice-1SG.POS and picture.PL "I sent them cassettes with my voice and pictures" 
${ }^{1}$ la puissance

${ }^{5}$ monoxyde de carbone

9 légiste

${ }^{13}$ la muraille de chine

${ }^{17}$ magma

${ }^{21}$ la chaleur

${ }^{25}$ les accords

${ }^{29}$ et comme

${ }^{33}$ les cassette
${ }^{2}$ le principle ${ }^{3}$ les paroles

${ }^{6}$ forger $\quad{ }^{7}$ des canons

${ }^{10}$ Archimède ${ }^{11}$ l'alchimiste

${ }^{14}$ la chaîne alpine ${ }^{15}$ les chutes de Niagara

${ }^{18}$ juste $\quad{ }^{19}$ centre

${ }^{22}$ l'alpiniste ${ }^{23}$ les pistes

${ }^{26}$ des corps $\quad{ }^{27}$ les paroles

${ }^{30}$ Blondie $\quad{ }^{31}$ Martin Luther King
${ }^{4}$ la fusion

${ }^{8}$ les granits

12 architecte

${ }^{16}$ les roches durs

${ }^{20}$ la Terre

${ }^{24}$ les cordes

${ }^{28}$ corps

${ }^{32}$ cauchemar

\section{SOUS FRANCE}

1. [le zən ${ }^{1} \quad$ lī $\mathrm{t}$-hagr-o]

DEF.PL youth REL demean.PERF-3M.OBJ

"The youth that they demeaned"

2. [l-espwa ${ }^{2}$ Pa-w lhīhə b५īd wro lo-bhar]

DEF-hope PROG-3M there far behind DEF-sea

"The hope is there far behind the sea"

3. [ye-b९ət l-ãmbasad ${ }^{3}$ dosia $^{4}$ wrə dosia $\left.{ }^{4}\right]$

3M-send.IMPF DEF-embassy file after file

"He sends the embassy file after file"

4. [kcjn lì b-Il-maSrif-a î-pūsiə $\left.{ }^{5}\right]$ exist.PERF REL by-DEF-connection 3M-push.IMPF

"There are those with connections they push"

5. [līwal $2 \mathrm{i}$-forsi $\left.{ }^{6}\right]$

someone 3M-force.IMPF

"Someone does his best"

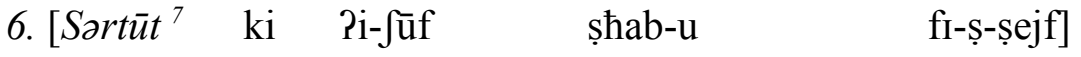

Especially when 3M-see.IMPF friend.PL-3M.POS in summer

"Especially when he sees his friends in the summer"

7. $\left[\right.$ l-orəp $^{8} \quad$ xarz-ət $\quad$ Salī-h $]$

DEF-Europe suit.PERF-3SG to-3M.OBJ

"Europe suits him"

8. [n-gatəS le ven $\left.{ }^{9}\right]$

$1 \mathrm{SG}$-cut.IMPF DEF.PL vein

"I cut the veins" 
9. [1-passport ${ }^{10} \quad \mathrm{j} \varepsilon$-Ggəd]

DEF-passport 3M-conclude.IMPF

"The passport is finished"

10. $\left[\mathrm{t}-k a \int \mathrm{a}^{l l}\right]$

3F-seal.IMPF

"It's sealed"

11. [gəlb-ək t-lafa ${ }^{12}$ ]

heart-2SG.POS 3F-relax.IMPF

"Your heart relaxes"

12. [deza ${ }^{13}$ șhab-ək min dork rā-k tə-twahef-hom]

already friend.PL-2SG.POS from now PROG-2SG 2SG-miss.IMPF-3PL.OBJ

"Now you're already missing your friends"

13. [roh-ək lïbara $\left.{ }^{14}\right]$

soul-2SG.POS free

"Your soul is free"

14. [a-k fərhān w mə-trāsi ${ }^{15}$ ]

PROG-2SG happy and PART-plan

"You are happy and planning"

15. [gudām-ək 1-fytuB ${ }^{16}$ ]

beside-2SG.OBJ DEF-future

"Beside you is the future"

16. [wra-k 1-passé $\left.{ }^{17}\right]$

behind-2SG.OBJ DEF-past

"Behind you is the past"

17. $\left[Q\right.$-gardi ${ }^{18} \quad 1-$ morāl $\left.^{19}\right]$

IMP-maintain DEF-sanity

"Maintain your sanity"

18. [je-bdə la $\quad k o f m \bar{a} r^{20}$ ]

3M-start.IMPF DEF.MASC nightmare

"The nightmare starts"

19. [?i-jī-w-ək la dwān $\left.{ }^{2 l}\right]$

3M-come.IMPF-PL-2SG.OBJ DEF.FEM customs

"Customs comes for you." 
20. [a-nī na-krə had or-rasa $\left.{ }^{22}\right]$ PROG-1SG 1SG-hate.IMPF DEM DEF-race "I hate this (biological) race"

21. [faq məf-ək tūrist ${ }^{23}$ ] discover.PERF NEG-2SG tourist

"He discovered you're not a tourist"

22. [jodī-k Sənd la polīs ${ }^{24}$ ] take.PERF-2SG.OBJ to DEF.FEM police "He takes you to the police"

23. [t-Yamr wahd la lisst $\left.{ }^{25}\right]$ 2SG-fill.IMPF one DEF.FEM list

"You fill out some list"

24. [?i-səksi-w-ək $\quad$ f $l a \quad p a f^{26}$ ]

3M-ask.IMPF-PL-2SG.OBJ in DEF.FEM border.control "They ask you in the PAF*"

* Police Aux Frontières ('border control')

25. [jyst ${ }^{27} \mathrm{j} \varepsilon$-provoki-w-kə ${ }^{28}$ ] just 3M-provoke.IMPF-PL-2SG.OBJ "Just to provoke you"

26. [?i-rofoli-w-kə ${ }^{29}$ ] 3M-turn.back-PL-2SG.OBJ

"They turn you back"

27. [visa ${ }^{30}$ tharg-ət] visa burn.PERF-2SG

"The Visa expired"

28. [ [and-ək Ga la polīs ${ }^{31}$ ] to-2SG.OBJ for DEF.FEM police "Watch out for the police"

29. [ma-Sand-ək hatə ha9 mS la lwa ${ }^{32}$ tof sarkozi ${ }^{33}$ ] NEG-to-2SG.OBJ even right with DEF.FEM law GEN Sarkozy "You don't even have a right under the laws of Sarkozy"

30. [t-roh la dipo $\left.{ }^{34}\right]$ 2SG-go.IMPF DEF.FEM stock.room "You go to a back room" 
31. [mbaYəd t-Yādi Teksplusi ${ }^{35}$ ]

after 2SG-return.IMPF deported

"After that you go back deported"

32. [lāzəm t-dīr $\left.\quad l-a z \bar{\imath} l^{36}\right]$

must 2SG-do.IMPF DEF-asylum

"You have to get asylum"

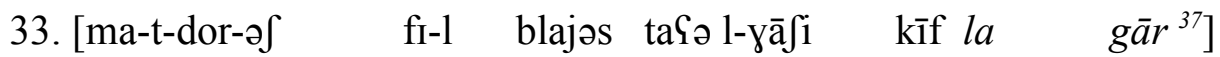

NEG-IMP-circle-NEG in-DEF place.PL GEN DEF-public like DEF.FEM train.station

"Don't hang out in public places like the train station"

34. [lazəm t-kasi ${ }^{38}$ ]

must 2SG-break.IMPF

"You have to break in"

35. [tə-skwati ${ }^{39}$ dār]

2SG-squat house

"You squat in a house"

36. [t-hız $\quad 1-g \bar{a} 3 u w-\bar{a} t^{40}$ fi-1 $\operatorname{mar}^{41}{ }^{41}$ Cand si $\left.x \bar{u}-n \bar{a}\right]$

2SG-carry.IMPF DEF-crate-PL in-DEF market to mister brother-3PL.POS

"You carry the crates at the market of Mr. so-and-so"

37. [ma-t-reklam-1 $\left.\int^{42}\right]$

NEG-2SG-ask.IMPF-NEG

"You don't ask" (reclaimer)

38. [Pi-gūl-u bi $\left.\tilde{\varepsilon}^{43}\right]$

3M-say.IMPF-PL good

"They say good"

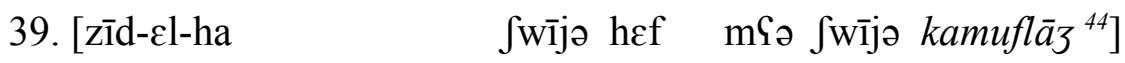
add.PERF-to-3FSG.OBJ little lie.PL with little camouflage

"He added to it some lies with some camouflage"

40. [anājə dirckt ${ }^{45}$ ]

1SG.PRO direct

"I am direct"

41. [Galədikə l-istwar ${ }^{46}$ ]

That.is DEF-story

"That is the story" 
McLain-Jespersen 99

${ }^{1}$ les jeunes
${ }^{5}$ pousser
${ }_{9}$ les veines
${ }^{13}$ déjà
${ }^{17}$ passé
${ }^{21}$ la douane
${ }^{25}$ la liste
${ }^{29}$ refouler
${ }^{33}$ Sarkozy
${ }^{37}$ la gare
${ }^{41}$ marché
${ }^{46}$ directe

${ }^{2}$ l'espoir
${ }^{6}$ forcer
${ }^{10}$ passeport
${ }^{14}$ libre
${ }^{18}$ garder
${ }^{22}$ race
${ }^{26}$ la PAF
${ }^{30}$ visa
${ }^{34}$ le dépôt
${ }^{38}$ casser
${ }^{42}$ réclamer
${ }^{47}$ l'histoire

${ }^{3}$ l'embassade

${ }^{7}$ surtout

${ }^{11}$ cacheter

${ }^{15}$ tracer

${ }^{19}$ moral

${ }^{23}$ touriste

${ }^{27}$ juste

${ }^{31}$ la police

${ }^{35}$ expulsé

${ }^{39}$ squatter

${ }^{43}$ bien
${ }^{4}$ dossier

${ }^{8}$ l'Europe

${ }^{12}$ lâcher

${ }^{16}$ futur

${ }^{20}$ le cauchemar

${ }^{24}$ la police

${ }^{28}$ provoquer

${ }^{32}$ la loi

${ }^{36}$ l'asile

${ }^{40}$ cageot

${ }^{45}$ camouflage

\section{ELM KBIR}

1. [lez istwar d-amūr ${ }^{1}$ dimə fi-hūm le problem $\left.{ }^{2}\right]$ DEF.PL story GEN-love always in-3PL.OBJ DEF.PL problem "Love stories always have problems"

2. [kān-ū hakak trãkīl ${ }^{3}$ mSI 1 1-ijəm-āt] be.PERF-3PL like.that peaceful with DEF-day-PL "They were peaceful for days"

3. [Q-PesmaS l-afer ${ }^{4}$ kifə bda-t]

IMP-listen DEF-matter how start.PERF-3SG

"Listen to how the matter began"

4. [jə-lYab-ha $\left.s \varepsilon r j \bar{u}^{5}\right]$ 3M-play.IMPF-3FSG.OBJ serious "He plays it serious"

\section{5. [?i-țjaj l-amsõ $\left.{ }^{6}\right]$}

3M-throw.IMPF DEF-hook

"He throws the hook."

6. [ja-ћsəb le dimõsjo $\left.{ }^{7}\right]$ 3SG-count.IMPF DEF.PL dimension "He counts the dimensions"

7. $\left[\begin{array}{lll}k a n & l a & t a j^{8}\end{array}\right]$ exist.PERF DEF.FEM size

"There's the size" 
8. [hijə ta-Sṭi-h bi-s-skaner ${ }^{9}$ ]

3FSG.PRO 3F-give.IMPF-3MSG.OBJ by-DEF-scanner

"She scans him"

9. [kūl sūpli ${ }^{10}$ sūpli $\left.{ }^{10}\right]$

everything smooth smooth

"Everything is okay"

10. [ləkan s-e bo $\left.\quad b \tilde{o}^{I I}\right]$

if it-be.PRES.SG good

"If $i t$ 's good"

11. [Yand-ək la Pi-jī-k ət-trā $k^{12}$ ]

to-2SG.OBJ NEG 3M-come.IMPF-2SG.OBJ DEF-nerves

"Be careful not to get nervous"

12. [lez istwar d-amūr wələ-w şāb kimə 1-bāk $\left.{ }^{14}\right]$

DEF.PL story GEN-love become.PERF-PL difficult like DEF-baccalaureat.exam

"Love stories became difficult like the baccalaureat exam"

13. [fi la duzijem zurne ${ }^{15}$ hna ț-ṭol a-wa sezī]

in DEF.FEM second day here DEF-child PROG-3MSG ready

"On the second day here the guy is ready"

14. [3ab-Il-ha ka3 a $\operatorname{trap}^{16} \mathrm{~b}$ le baro $^{17}$ ta9 sirkezi]

bring.PERF-to-3FSG.OBJ cage to trap by DEF.PL bar GEN Serkadji

"He brought her a trap cage with bars like Serkadji*"

*Serkadji is a famous prison in Eastern Algeria

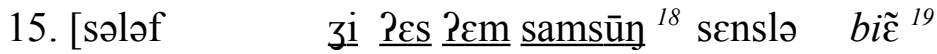

borrow.PERF $\underline{G} \underline{\mathrm{S}} \underline{\mathrm{M}} \underline{\text { Samsung necklace good }}$

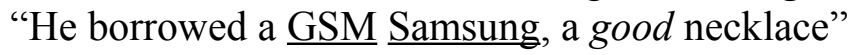

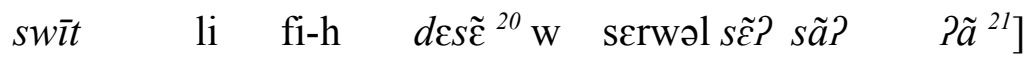

sweatshirt REL in-3SG design and jeans five hundred one

"a sweatshirt with a design and 501 jeans"

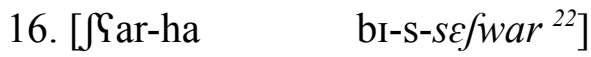

hair-3FSG.POS by-DEF-dryer

"Her hair in a dryer"

17. [rōh $\quad$ Pa $\left.\quad b l \tilde{o}^{23}\right]$

IMP-go EVOC blond

"Go, you blond." 
18. [?er katr ${ }^{24}$ Yafq-ət fĩ Patas $^{25}$ ]

$R \quad 4$ love.PERF-3FSG in Atos

"An $R 4$ was in love with an Atos"

19. $\left[\right.$ Pi-bifi $\left.{ }^{26}\right]$

3M-be.prideful.IMPF

"He is prideful"

20. [?a-w

gaYd

Pi-fūrni $\left.{ }^{27}\right]$

PROG-3MSG continue.PARTIC 3M-give.IMPF

"He keeps giving"

21. [?a-j dimar-at $\left.{ }^{28}\right]$

PROG-3FSG start.PERF-3FSG

"She has started"

22. [Pi-rkəb-ha fi le bus ${ }^{29}$ ]

3M-ride-3FSG.OBJ in DEF.PL bus

"He made her ride on buses"

23. [? a plus $^{30}$ faq-ət]

in addition discover.PERF-3F

"In addition she discovered"

24. [ [ pand-u portabl ${ }^{31}$ b-la la pus $^{32}$ ]

to-3MSG.OBJ mobile.phone by-NEG DEF.FEM chip

"He has a mobile phone without the SIM card"

25. $\left[\operatorname{surtu}^{33}\right.$ ki faq $]$

Especially when discover.PERF

"Especially when he discovered"

${ }^{1}$ les histoires d'amour

${ }^{5}$ sérieux

${ }^{9}$ scanner

${ }^{13}$ les histoires d'amour

${ }^{17}$ les barreaux

${ }^{21} 501$

${ }^{25}$ Atos

${ }^{29}$ les bus

${ }^{33}$ surtout

${ }^{2}$ les problèmes
${ }^{6}$ l'hamecon
${ }^{10}$ souple
${ }^{14}$ bac
${ }^{18}$ GSM Samsung
${ }^{22}$ séchoir
${ }^{26}$ bicher
${ }^{30}$ en plus

${ }^{3}$ tranquil

${ }^{7}$ les dimensions

${ }^{11}$ c'est bon

${ }^{4}$ l'affaire

${ }^{8}$ la taille

${ }^{15}$ la deuxieme journée

${ }^{19}$ bien

${ }^{23}$ blond

${ }^{12}$ trac

${ }^{16}$ cage à trappe

${ }^{20}$ dessin

${ }^{27}$ fournir

${ }^{24} \mathrm{R} 4$

${ }^{31}$ portable

${ }^{28}$ démarrer

32 la puce 


\section{AMERIKA}

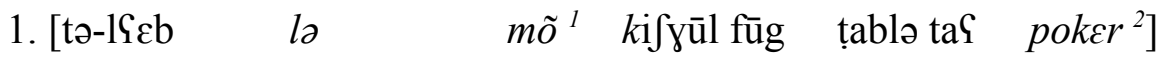
3F-play.IMPF DEF.MASC world like above table GEN poker

"It plays the world like on a poker table"

2. [darb-ō-ha fi-s-sãtr ${ }^{3}$ ]

hit.PERF-PL-3FSG.OBJ in-DEF-center

"They hit in the center"

3. [wal-et $\left.\quad s o m b r^{4}\right]$

become.PERF-3F somber

"They became somber"

4. [Pəslāh fi-hūm Pəf- $\left.\int a k^{5}\right]$

INTENS in-3PL.OBJ DEF-shock

"They were really shocked."

5. [?ã plus ${ }^{6}$ lo kerozen $^{7}$ hūwə li dūwəb la $\quad$ farpãtar ${ }^{8}$ ] in addition DEF.MASC kerosene 3M.PRO REL melt.PARTIC DEF.FEM framework "Also it was the kerosene that melted the framework"

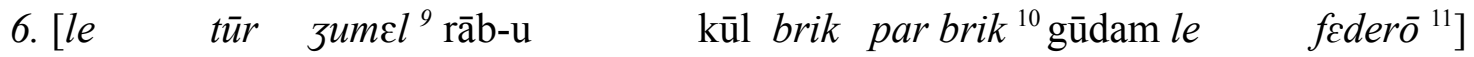
DEF.PL tower twin fell.PERF-3PL all brick by brick beside DEF.PL federal "The twin towers fell all brick by brick in front of the federals"

7. [fi nōsf le flām ${ }^{12} \mathrm{w}$ nirān lgā-w in center DEF.PL flame and fire find.PERF-3PL

"In the middle of flames and fire they found"

paspō $r^{13} \mathrm{~W}$ kasct Podiō ${ }^{14}$ fə-ha 1-korān] passport and cassette audio in-3F.PRO DEF Quran "A passport and an audio cassette with the Quran"

8. [qbəlmə bde-t l-ãket ${ }^{15}$ ]

before start.PERF-3SG DEF-investigation

"Before the investigation started"

9. [jāb-u 1-kopabla ${ }^{16}$ ]

bring.PERF-3PL DEF-guilty

"They brought the guilty." 
10. $\left[\right.$ brãf-āw le kābla $\left.{ }^{17}\right]$

connect.PERF-3PL DEF.PL cable

"They connected the cables."

11. $\left[k_{k r a z-\bar{a} w^{18}} \quad l e \quad m \bar{o} \quad\right.$ kimo skrābla $\left.{ }^{19}\right]$

cross.PERF-3PL DEF.PL word like Scrabble

"They crossed the words like Scrabble"

12. [la diabl ${ }^{20}$ Sa-bāl-u mə-l-ūwəl]

DEF.MAC devil to-mind-3M.POS from-DEF-start

"The devil knew from the start"

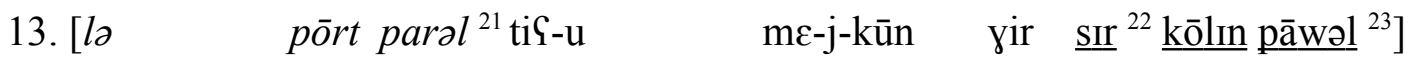

DEF.MASC door word GEN-3M.OBJ 3M-be.IMPF only $\underline{\text { ir } \text { Colin Pawel }}$

"His spokesman is none other than Sir Colin Pawel"

14. [t-tsāwər $\quad 3 \bar{a}-\mathrm{w} \quad$ bI-s-satilīt $\left.{ }^{24}\right]$

DEF-picture.PL come.PERF-3PL by-DEF-satellite

"The pictures came by satellite"

15. [nāSt-u le cã $\quad d$-ãtrẽma $\tilde{a}^{25}$ taS le taleb $\tilde{a}^{26}$ ] describe.PERF-3PL DEF.PL camp GEN-training GEN DEF.PL Taliban

"They showed the training camps of the Taliban"

16. $\left[3 \varepsilon-\mathrm{t} \quad\right.$ la $\quad$ rãs $\left.\tilde{o}^{27}\right]$

come.PERF-3F DEF.FEM ransom

"The ransom came"

17. [ta-bg-u la misjo $\left.{ }^{28}\right]$

2-finish.PERF-PL DEF.FEM mission

"You all finished the mission"

18. [t-saksi Sa-1-bila $\left.{ }^{29}\right]$

2SG-ask.IMPF about-DEF-outcome

"You ask about the outcome"

19. [vãz-āw le trã mīl $\left.{ }^{30}\right]$

avenge.PERF-3PL DEF.PL three thousand

"They avenged the three thousand"

20. [getl-u de mīljo ${ }^{31}$ ]

kill.PERF-3PL INDEF.PL million

"They killed millions." 
21. [bda-t $\operatorname{deg} a^{32}$ ] start.PERF-3F damage "damage started"

22. $\left[s^{\prime} e^{33}\right.$ lo puvwarnwar ${ }^{34}$ taS l-ãpīr do amerik $\left.\bar{a}^{35}\right]$ it-be.PRES.SG DEF.MAC power black GEN DEF-empire GEN America "It's the black power of the American empire"

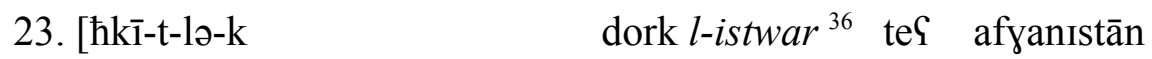
speak.PERF-1SG-to-2SG.OBJ now DEF-story GEN Afghanistan "I just told you the story of Afghanistan"

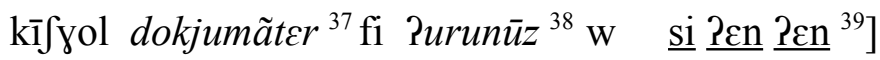
like documentary in Euronews and $\underline{\mathrm{C}} \underline{\mathrm{N}} \underline{\mathrm{N}}$ "Like a documentary on Euronews and $\underline{\mathrm{CNN}}$ "

24. [fa-ha $m \overline{i z} \quad \tilde{a} \operatorname{sen}^{40}$ kastin $^{41} \mathrm{~W} \quad$ scnarijo $^{42}$ ] in-3FSG setting in scene casting and script "It has a directing, casting and a script"

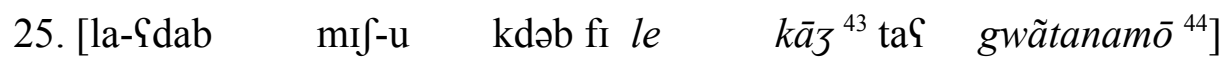
DEF-torment NEG-3M lie in DEF.PL cage GEN Guantanamo "The torment isn't a lie in the cages of Guantanamo"

26. [le servō ${ }^{45}$ tạ la mejsõ blãa ${ }^{46}$ Pā-m lhīk] DEF.PL brain GEN DEF.FEM house white PROG-3PL there "The brains of the white house are there"

27. [3āb-u le soldāt ${ }^{47}$ ta؟ la $\quad$ ger ${ }^{48}{ }^{3 i o w}$ iokonomīk ${ }^{49}$ ] bring.PERF-3M DEF.PL soldier GEN DEF.FEM war geoeconomic "They brought the soldiers of the geoeconomic war"

28. $\left[Q-3 \bar{i} b \quad\right.$ la $\quad$ kart $^{50}$ 3iografik $\left.^{51}\right]$

IMP-bring DEF.FEM map geographic

"Bring the geographic map"

29. $\left[Q-\int \mathrm{u} f \quad\right.$ fi-l- $\left.a z \bar{i}^{52}\right]$

IMP-look in-DEF-Asia

"Look to Asia"

30. [te-lgə blāṣə stratizīk $\left.{ }^{53}\right]$

2SG-find.IMPF place strategic

"You find a strategic place" 
31. [kajn-ə bhar șyīr fi-h tresor $^{54}$ kbīr] exist.PERF-FEM sea small in-3MSG treasure big

"There's a small sea with a big treasure in it"

32. [Q-zīd Pirān li fi lo syd $\left.{ }^{55}\right]$

IMP-add Iran REL in DEF.MASC south

"Additionally, Iran is in the south"

33. [t-wili põ ${ }^{56}$ bin-əl pākistã ${ }^{57} \mathrm{~W}$ turkmenistã ${ }^{58}$ ]

2SG-become.IMPF bridge between-DEF Pakistan and Turkmenistan

"To make a bridge between Pakistan and Turkmenistan"

34. [?ā-m tras-āw ${ }^{59}$ dork lo plã $\left.{ }^{60}\right]$

PROG-3PL draw.PERF-3PL now DEF-MASC plan

"They already drew the plan"

35. $\left[Q-3 \overline{1} \mathrm{~b}\right.$ le blã $\left.{ }^{61}\right]$

IMP-bring DEF.PL white

"Bring the whites"

36. $\left[Q-3 \overline{1} \mathrm{~b} \quad\right.$ l-aktur $\left.{ }^{62}\right]$

IMP-bring DEF-actor

"Bring the actor"

37. $\left[Q-3 \overline{1} \mathrm{~b}\right.$ le $\left.k \tilde{o}^{63}\right]$

IMP-bring DEF.PL idiot

"Bring the idiots"

38. [l-espwar ${ }^{64}$ taS-ha Pā-w bīn-əs-smā wə-l-hsīra]

DEF-hope GEN-3FSG PROG-3MSG between-DEF-sky and-DEF-prayer.rug

"Its hope is between the sky and the prayer rug"

39. [mif-o Sand $l$-ont $\left.{ }^{65}\right]$

NEG-3M to DEF-United.Nations

"It's not in the United Nations"

40. [wələ Pibrīd ${ }^{66}$ w mxədər]

become.PERF cross-breed and anesthetized

"It became a cross-breed and anesthetized"

41. [l-istwar ${ }^{67}$ taS 1-a9rob wala-t kimə yn bessele $\left.{ }^{68}\right]$ $D E F$-story GEN DEF-Arab become.PERF-3F like INDEF.MASC best.seller "The story of the Arabs became a best seller" 
42. [?en-nas $\left.3 \bar{a} m e^{69} \mathrm{nsc}-\mathrm{t}\right]$

DEF-people never forget.PERF-2FSG

"The people never forgot"

43. [乌arəbsāt jə-ৎəs kI-1-miradōr ${ }^{70}$ ]

ArabSat 3M-watch.IMPF like-DEF-watchtower

"ArabSat watches like a watchtower"

44. [Yam-bāl-u f həd la $m \tilde{d}{ }^{71}$ Jkun hūwə lo predatō $\left.r^{72}\right]$ about-mind-3M.POS in DEM DEF.MASC world who 3M.PRO DEF.MASC predator "He knows in this world who is the predator"

45. $\left[1 \overline{1}\right.$ jə-med fi $\left.l a \quad m \bar{o} r^{73}\right]$

REL 3M-give.IMPF in DEF.FEM death

"Who gives death"

46. [?i-sījb l- $\quad$ sssktısidd $\left.{ }^{74}\right]$

3M-spread.IMPF DEF-insecticide

"He spreads the insecticide"

47. $\left[1 \overline{1}\right.$ Sand-u le misīl ${ }^{75} \mathrm{~W} \quad$ l-arm $^{76} \quad$ distraksjõ masīv $\left.{ }^{77}\right]$

REL to-3MSG DEF.PL missile and DEF-weapon destruction massive "Who has the missiles and the weapons of mass destruction"

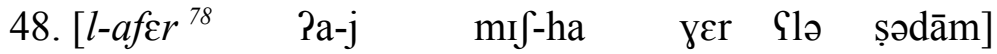

DEF-matter PROG-3F NEG-3FSG only about Saddam

"The situation is not only about Saddam"

${ }^{1}$ le monde

${ }^{5}$ choc

${ }^{9}$ les tours jumelles

${ }^{13}$ passeport

${ }^{17}$ câbles

${ }^{21}$ le porte paroles

${ }^{25}$ les camps d'entrainement

${ }^{29}$ bilan

${ }^{33}$ c'est

${ }^{37}$ documentaire

${ }^{41}$ casting

${ }^{45}$ les cerveaux

${ }^{49}$ géo-économique

${ }^{53}$ stratégique

${ }^{57}$ Pakistan

${ }^{61}$ les blanches

${ }^{65} l^{\prime} \mathrm{ONU}$

$\begin{array}{ll}{ }^{2} \text { poker } & { }^{3} \text { centre } \\ { }^{6} \text { en plus } & { }_{7}^{7} \text { le kérosène } \\ { }^{10} \text { brique par brique } & { }^{11} \text { les fédéraux } \\ { }^{14} \text { cassette audio } & { }^{15} \text { l'enquete } \\ { }^{18} \text { croiser } & { }^{19} \text { Scrabble } \\ { }^{22} \text { Sir } & { }^{23} \text { Colin Pawel } \\ { }^{26} \text { les talibans } & { }^{27} \text { la rançon } \\ { }^{30} \text { les trois milles } & { }^{31} \text { des millions } \\ { }^{34} \text { le pouvoir noir } & { }^{35} \text { l'empire de America } \\ { }^{38} \text { euronews } & { }^{39} \text { CNN } \\ { }^{42} \text { scènario } & { }^{43} \text { les cages } \\ { }^{46} \text { la maison blanche } & { }^{47} \text { les soldats } \\ { }^{50} \text { la carte } & { }^{51} \text { géographique } \\ { }^{54} \text { trésor } & { }^{55} \text { le sud } \\ { }^{58} \text { Turkménistan } & { }^{59} \text { tracer } \\ { }^{62} \text { l'acteur } & { }^{63} \text { les cons } \\ { }^{66} \text { hybride } & { }^{67} \text { l'histoire }\end{array}$

${ }^{4}$ sombre

${ }^{8}$ la charpente

${ }^{12}$ lés flammes

${ }^{16}$ le coupable

${ }^{20}$ le diable

${ }^{24}$ satellite

${ }^{28}$ la mission

${ }^{32}$ dégât

${ }^{36}$ l'histoire

${ }^{40}$ mise en scène

${ }^{44}$ Guantanamo

${ }^{48}$ la guerre

${ }^{52}$ l'Asie

${ }^{56}$ pont

${ }^{60}$ le plan

${ }^{64}$ l'éspoir

${ }^{68}$ un best seller 
${ }^{69}$ jamais

${ }^{73}$ la mort

${ }^{77}$ destruction massif
${ }^{70}$ mirador

${ }^{74}$ l'insecticide

${ }^{78}$ l'affaire
${ }^{71}$ le monde

${ }^{75}$ les missiles
${ }^{72}$ le prédator

${ }^{76}$ l'arme

\section{C'EST MAGIQUE}

1. [bdī-t rāp ${ }^{1}$ par hazar $\left.{ }^{2}\right]$ start.PERF-1SG rap by accident "I started rap by accident"

2. [kān-ət $\left.\quad b i z \bar{a} r^{3}\right]$ be.PERF-3F bizarre "It was bizarre."

3. [s-sistem ${ }^{4} \quad \mathrm{mI}-\mathrm{u} \quad \mathrm{sah}$ l] DEF-system NEG-3MSG easy "The system isn't easy"

4. [ma-der-t-əS solf $\varepsilon 3^{5}$ ] NEG-do.PERF-1SG-NEG notation

"I didn't make notations"

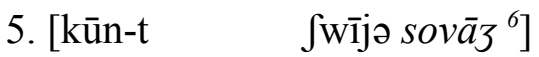

be.PERF-1SG little wild

"I was a little wild"

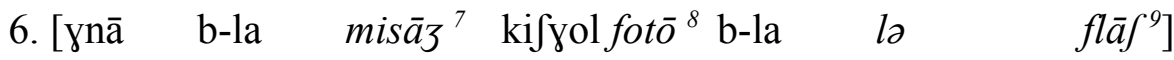
singing by-NEG message like photo by-NEG DEF.MASC flash "Singing without a message is like a photo without the flash"

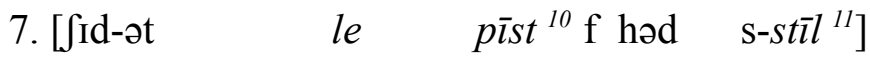
get.PERF-1SG DEF.PL track in DEM DEF-style "I got the tracks in that style"

8. [bdī-t nə-riskī $\left.{ }^{12}\right]$ start.PERF-1SG 1SG-risk.IMPF "I started to risk"

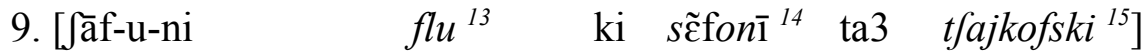
see.PERF-3PL-1SG unfocused like symphony GEN Tchaikovsky "They saw me as crazy like a Tchaikovsky symphony" 
10. [?awəl l-cditur ${ }^{16}$ gāl-1-i]

DEF-first $D E F$-editor say.PERF-to-1SG.OBJ

"The first editor said to me"

11. [Pi-swisidi $\left.{ }^{17}\right]$

3M-commit.suicide.IMPF

"he commits suicide"

12. [ma-j-eșlah fi kasct $\left.^{18}\right]$

NEG-3M-fit.IMPF in cassette

"It won't work on tapes"

13. [ma-j-eșlah fi le sì $\left.d \bar{\imath}^{19}\right]$

NEG-3M-fit.IMPF in DEF.PL $C D$

"It won't work on $C D s$ "

14. [fi la $v w a^{20}$ Pa-ni

in DEF.FEM voice PROG-1SG mute

"My voice is mute"

15. [ma-sījb-t-əð had l-afer ${ }^{21}$ ]

NEG-release.PERF-1SG-NEG DEM DEF-matter

"I didn't let this matter go"

16. [mem ${ }^{22}$ ləkān-u trāzik $\left.{ }^{23}\right]$

even if-3MSG tragic

"Even if it's tragic"

17. $\left[s-e^{24} \quad m a \quad m i s j \tilde{o}^{25} m a \quad\right.$ pasjo ${ }^{26}$

it-be.PRES.SG 1SG.POS mission 1SG.POS passion

"It's my mission, my passion"

$m \tilde{o} \quad$ fil do konkksjo ${ }^{27}$ bin-i $\quad$ W bin $\quad m a \quad$ nasjo $^{28}$ ]

ISG.PRO wire GEN connection between-1SG.PRO and between 1SG.POS nation

"my wire of connection between me and my nation"

18. [lo duzijam Peditur ${ }^{29}$ gāl-1-i]

DEF.MASC second editor say.PERF-to-1SG.OBJ

"The second editor said to me"

19. [șāh $\overline{\mathrm{a}}-\mathrm{k} \quad$ Pa fors $\left.{ }^{30}\right]$

INTEN PROG-2SG in force

"Indeed you're forceful" 
20. [?i-dati-w-ək ${ }^{31}$ bI-1-karbõ katōrz ${ }^{32}$ ]

3M-date.IMPF-PL-2SG.OBJ by-DEF-carbon fourteen

"They date you with Carbon 14"

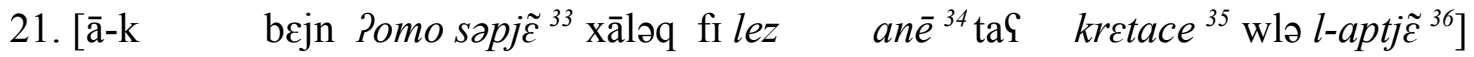
PROG-2SG clear homo sapien created in DEF.PL year GEN Cretaceous or DEF-Aptian "You're clearly a homo sapien created in the Cretaceous or Aptian age"

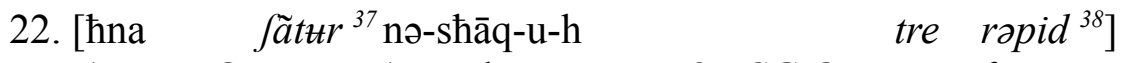

1PL.PRO singer 1-crush.PERF-PL-3MSG.OBJ very fast

"Us, we crush a singer very fast"

23. [jə-yəni fi-l-vī $\left.d^{39}\right]$

3M-sing.PERF in-DEF-empitness

"He sings nonsense"

24. [?i-3īb-əl-na swārəd vīt ${ }^{40} v \bar{\imath} t^{40}$ ]

3M-bring.IMPF-to-1PL.OBJ money quick quick

"He brings us money quickly"

25. [nə-plõzi-w ${ }^{41}$ kūl Sli-h]

1-jump.IMPF-PL all to-3MSG.OBJ

"We all jump on him"

26. [l-artist ${ }^{42}$ galb-u-h balo $\left.{ }^{43}\right]$

DEF-artist transform.PERF-3PL-3MSG.OBJ ball

"They turn the artist into a ball"

27. [ja-hsab-u-h dimino $^{44}$ ]

3-consider.IMPF-PL-3MSG.OBJ domino

"They consider him a domino"

28. [fi rās-u kejn dūbl bla ${ }^{45}$ ]

in head-3M.POS exist.PERF double white

"In his head there's a double white"

29. [ma-t-kūn-əऽ $\left.k \tilde{a}^{46}\right]$

NEG-2SG-be.IMPF-NEG idiot

"Don't be an idiot"

30. [Pəncja sufrī-t ${ }^{47}$ fI-d-domān ${ }^{48}$ ]

1SG.PRO suffer.PERF-1SG in-DEF-domain

"I suffered in this field" 
31. $\left[r \bar{a} p^{49}\right.$ tą-i yedī-ni fi vojāj ${ }^{50}$

rap GEN-1SG take.PERF-1SG.OBJ in voyage

"My rap takes me on a journey"

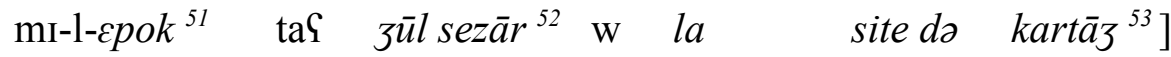

from-DEF-age GEN Julius Cesar and DEF.FEM city GEN Carthage

"from the age of Julius Cesar and the city of Carthage"

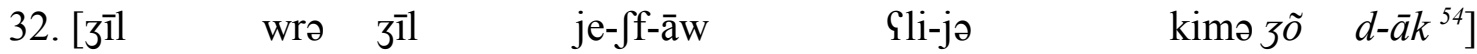
generation behind generation 3M-look.IMPF-PL about-1SG.OBJ like Joan D'Arc "Generation after generation sees me as Joan of Arc"

33. [n-xali atār kimole $r w \overline{i n n}{ }^{55}$ tå bizanța] 1SG-keep.IMPF trace.PL like DEF.PL ruin GEN Byzantium "I keep traces like the ruins of Byzantium"

34. [n-dīr $\quad l a \quad$ finisjo ${ }^{56}$ ]

1SG-do.IMPF DEF.FEM finishing

"I do the finishing touches"

35. [Gand-i lo sõ de finisje $\tilde{\varepsilon}^{57}$ ] to-1SG DEF.MASC sense INDEF.PL Phonecian "I have the sense of the Phonecians"

36. [kristof kolōm $^{58}$ daћk-o Cli-h] Christopher Columbus laugh.PERF-3PL about-3MSG.OBJ

"They laughed at Christopher Columbus"

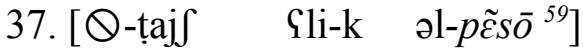

IMP-give.up to-2SG DEF-brush

"Give up the brush"

$\begin{array}{llll}{ }^{1} \text { rap } & { }^{2} \text { par hasard } & { }^{3} \text { bizarre } & { }^{4} \text { système } \\ { }^{5} \text { solfège } & { }^{6} \text { sauvage } & { }^{7} \text { message } & { }^{8} \text { photo } \\ { }^{9} \text { le flash } & { }^{10} \text { les piste } & { }^{11} \text { style } & { }^{12} \text { risquer } \\ { }^{13} \text { flou } & { }^{14} \text { symphonie } & { }^{15} \text { Tchaïkovski } & { }^{16} \text { l'editeur } \\ { }^{17} \text { suicider } & { }^{18} \text { cassette } & { }^{19} \text { les CD } & { }^{20} \text { la voix } \\ { }^{21} l^{2} \text { 'affaire } & { }^{22} \text { même } & { }^{23} \text { tragique } & { }^{24} \text { c'est } \\ { }^{25} \text { ma mission } & { }^{26} \text { ma passion } & { }^{27} \text { mon fil de connection }{ }^{28} \text { ma } \text { nation } \\ { }^{29} \text { le deuxième éditeur }{ }^{30} \text { en force } & { }^{31} \text { dater } & { }^{32} \text { carbone quatorze } \\ { }^{33} \text { homo sapien } & { }^{34} \text { les années } & { }^{35} \text { crétacé } & { }^{36} \text { l'aptien } \\ { }^{37} \text { chanteur } & { }^{38} \text { très rapide } & { }^{39} \text { vide } & { }^{40} \text { vite } \\ { }^{41} \text { plonger } & { }^{42} \text { l'artiste } & { }^{43} \text { ballon } & { }^{44} \text { domino } \\ { }^{45} \text { double blanc } & { }^{46} \text { con } & { }^{47} \text { souffrir } & { }^{48} \text { domaine }\end{array}$




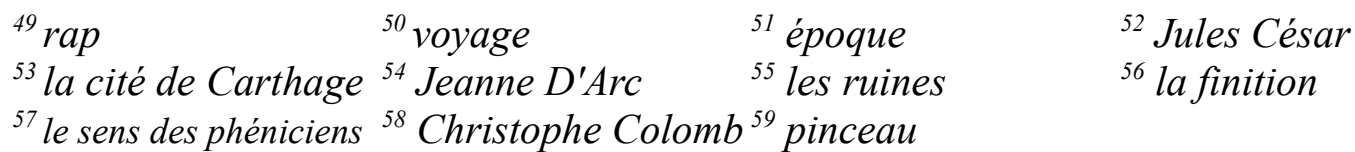

\section{$\underline{\text { 6. KOBAY }}$}

1. [tlatīn snā min hjāt-i Gad-āw nwar ${ }^{1}$ ] thirty year.PL from life-1SG.POS pass.PERF-3PL black

"Thirty years of my life passed in the dark"

2. [jə-ћsəb-ō-nə de kobaj $^{2}$ ]

3M-consider.IMPF-PL-1PL.OBJ INDEF.PL guinea.pig

"They think we're guinea pigs"

3. [lo-bled wole-t laboratwār $\left.{ }^{3}\right]$

DEF-country become.PERF-3FSG laboratory

"The country became a laboratory"

4. [kān-ət $\quad$ fot $^{4} \quad$ mōnumãtāl $\left.{ }^{5}\right]$

be.PERF-3FSG mistake monumental

"It was a monumental mistake"

5. [dār-u șah fāwdə $\left.m o \tilde{t} t \bar{a} l^{6}\right]$

did.PERF-3PL INTEN chaos mental

"They really made mental chaos"

6. [3āb-u-nā la $\quad$ civjer ${ }^{7}$ sirōm $^{8}$ $^{\text {Pancstiz }}{ }^{9}$ w mSə srīr fi-s-simtjer ${ }^{10}$ ] bring.PERF-3PL-1PL.OBJ DEF.FEM stretcher serum anesthetic and with bed in-DEF-cemetary "They brought us the stretcher, serum, anesthesia and with a bed in the cemetary"

7. [kūn dxəl-t f həd d-domen $\left.{ }^{11}\right]$

if enter.PERF-1SG in DEM DEF-domain

"If I entered this field"

8. [n-Yādi $\quad \operatorname{mem}^{12}$ lo $\left.n \bar{i} s^{13}\right]$

1SG-pass.IMPF even DEF.MASC Nice

"I'll even go to Nice"

9. [ne-xdəm miə la mafjorts ${ }^{14}$ ]

1SG-work.IMPF with DEF.FEM mafia Russian

"I work with the Russian mafia" 
10. [ja-Ytịi-w-ni la kocajīn ${ }^{15}$ ]

3M-give.IMPF-PL-1SG.OBJ DEF.FEM cocaine

"They'll give me the cocaine"

11. [na-Yṭi-hom lo kanəbīs ${ }^{16}$ ]

1SG-give.IMPF-3PL.OBJ DEF.MASC cannabis

"I'll give them the cannabis"

12. [?a-m Sand-i le kombin $^{17}$ ]

PROG-3PL to-1SG DEF.PL trick

"I have all the tricks"

13. [n-wıli kīf l-ạbād $r \bar{y}{ }^{18}$ fi-l-blād]

1SG-become.IMPF like DEF-people rich in-DEF-country

"I'd become like the rich people in the country"

14. [zāme ${ }^{19}$ ja-hkm-u-ni]

never 3M-arrest-PL-1SG.OBJ

"They'd never arrest me"

15. [jə-gelb-u-ni or-rakaj ${ }^{20}$ ]

3M-transform-PL-1SG.OBJ DEF-gangster

"They turn me into a gangster"

16. [ān-i șah kamikāz $\left.{ }^{2 l}\right]$

PROG-1SG INTEN kamikaze

"I am truly a kamikaze"

17. [məf-ni kobaj $\left.^{22}\right]$

NEG-1SG.OBJ guinea.pig

"I'm not a guinea pig"

18. [Q-nhasə-1-ha f la sosjete $^{23}$ ]

IMP-blame-to-3FSG.OBJ in DEF.FEM society

"blame it on the society"

19. $\left[1 \overline{1}\right.$ janə publisjete $\left.{ }^{24}\right]$

REL 1SG.PRO publicity

"For me it's publicity"

20. [mis-ni sovāz $\left.{ }^{25}\right]$

NEG-1SG wild

"I'm not wild" 
21. [rāh fi vojā̧ $\left.{ }^{26}\right]$

go.PERF in vacation

"He goes on vacation"

22. [hadəmə dez $\quad a f \varepsilon r^{27}$ n-xali-hūm $\quad$ li-d-drari ṣ-ṣyār]

DEM.PL INDEF.PL affair 1SG-allow.IMPF-3PL.OBJ to-DEF-children DEF-small.PL

"I let small children have these things"

23. [me proze ${ }^{28}$ hom kbār]

ISG.POS.PL project 3PL.PRO big.PL

"My projects are big"

24. [Cazb-ət-Ik əs-sərqā bi lo $\quad$ cric $^{29}$ ]

pleasure-FEM-2SG.POS DEF-stealing by DEF.MASC jack

"You like stealing with a jack"

25. [tə-rbəh de miljõ ${ }^{30} \mathrm{f}$ aksjo ${ }^{31}$ ]

2SG-win.IMPF INDEF.PL million in action

"You win millions in an action"

26. [lāzmI-tık de kõplīs ${ }^{32}$ f $l a \quad$ post $^{33} \quad$ f la $l a b a \tilde{k}{ }^{34}$ ] must-2SG INDEF.PL accomplice in DEF.FEM post.office in DEF.FEM bank "You need some accomplices in the post-office in the bank"

27. [Q-nāhi Palf 1 -freyk ${ }^{35}$ mI la $\quad$ pej ${ }^{36}$ ]

IMP-take thousand DEF-franc from DEF.FEM salary

"Take a thousand francs from the pay"

28. [fi sõ mīl salarje ${ }^{37} Q$-təlaS gdah rbah-t]

in hundred thousand salary IMP-guess how.much won.PERF-2SG

"guess how much you won from 100,000 salaries"

29. [Q-ৎāwəd dīmə həd l-afer ${ }^{38}$ ]

IMP-repeat always DEM DEF-affair

"Always repeat the affair"

30. [t-wəli Parfimiljarder ${ }^{39}$ ]

2SG-become.IMPF multimillionaire

"you become a multimillionaire"

31. [der-t-Il-ha brakāz a l-italjān ${ }^{40}$ ] do.PERF-1SG-to-3FSG.OBJ hold-up to DEF-Italian

"I did them like The Italian Job" 
32. $\left[\mathrm{n}-b r \tilde{a} / \mathrm{i}^{41} \quad \operatorname{mon} \operatorname{arz}^{42}\right]$

1SG-connect.IMPF 1SG.POS.MASC money

"I'll connect my money"

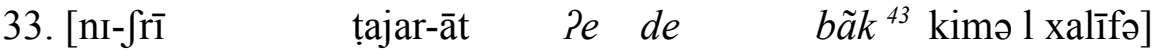

1SG-buy.IMPF airplane-PL and INDEF.PL bank like Al Khalifa

"I'd buy airplanes and banks like Al Khalifa"

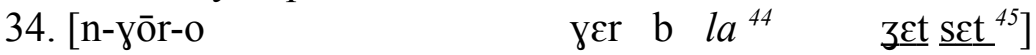

1SG-mislead.IMPF-3M.OBJ only by DEF.FEM jet set

"I mislead him only with the high life"

35. [n-Gawən ma patri $\left.{ }^{46}\right]$

1SG-help.IMPF 1SG.POS country

"I'd help my country"

36. [n-finãse de partī $\left.{ }^{47}\right]$

1SG-finance.IMPF INDEF.PL party

"I'd finance some parties"

37. [la tõp ${ }^{48} \mathrm{n}$-farze $e^{49}$ le batri $\left.{ }^{50}\right]$

DEF.MASC time 1SG-charge.IMPF DEF.PL battery

"While I charge my batteries"

38. [həd l-afer ${ }^{51}$ fa-ha rolasjo $\tilde{o}^{52}$ ]

DEM DEF-affair in-3FSG relation

"This affair has a relation"

39. [?ā-ni blõc ${ }^{53}$ pūrlo momã $\left.{ }^{54}\right]$

PROG-1SG white for DEF.MASC moment

"I am white for the moment"

40. [purtã ${ }^{55}$ Pā-ni meћtāza pu pre ${ }^{56} t w a$ sã mıljõ $\left.{ }^{57}\right]$ however PROG-1SG need to little near three hundred million "Though I need approximately three hundred million"

41. [1āzəm-ni yer sakreter $\left.{ }^{58}\right]$ must-1SG only secretary

"I only need a secretary."

42. [n-dīr mSa-ha detūrnomã $\left.\tilde{a}^{59}\right]$

1SG-do.IMPF with-3FSG fraud

"I'd commit fraud with her." 
43. [hom fi-l-örop ${ }^{60}$ Sajf-īn $\quad$ bSād]

3PL.PRO in-DEF-Europe live.PARTIC-PL far.PL

"they are in Europe living well"

44. [kūn-t qādər $m \varepsilon m^{61}$ n-kāli l-hājt tul nhār] be.PERF-1SG able.PARTIC even 1SG-hold.IMPF DEF-wall.PL length day "I even could have held up the walls the whole day"

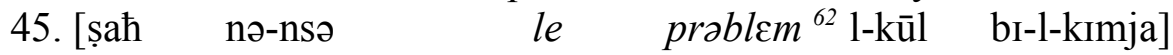

INTEN 1SG-forget.IMPF DEF.PL problem DEF-all by-DEF-smoking

"Of course I'd forget all the problems by smoking"

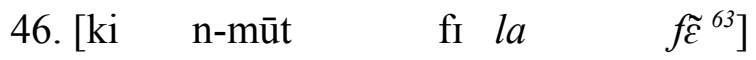

when $1 \mathrm{SG}$-die.IMPF in DEF.FEM end

"When I die in the end"

47. [kun-t qādər $\left.\quad \sin ^{64}\right]$

be.PERF-1SG able.PARTIC otherwise

"Otherwise I could have"

48. [n-filəg le pumõ ${ }^{66}$ bI-l-kīf wo djazep $\tilde{a}^{66}$ ]

1SG-shred DEF.PL lung by-DEF-marijuana and valium

"I destroy my lungs with marijuana and valium"

49. [?i-soti-w-1-i ${ }^{67}$ hnə le bulo ${ }^{68}$ ]

3M-blow.up.IMPF-PL-to-1SG.OBJ here DEF.PL bolt

"Here, my bolts would blow up on me (go crazy)"

50. [?aw fõ ${ }^{69}$ t-so-ha bī-ha]

to.DEF bottom 2SG-dismay.IMPF-3FSG.OBJ by-3FSG

"Basically you are dismayed by it"

51. [la corps $^{70} \mathrm{jI}$-tfur $]$

"DEF.MASC body 3M-sink.IMPF

"The body wastes away"

52. [b-nisbə li-hūm hnaja Peksperijõs ${ }^{71}$ ]

by-opinion to-3PL 1PL.PRO experiment

"according to them we're an experiment"

53. [?i-zīd-o f la $d \bar{o} S^{72}$ ]

3M-increase.IMPF-PL in DEF.FEM dose

"They increase the dose" 
54. [Q-zīb l-zrānjam $\left.{ }^{73}\right]$

IMP-bring DEF-uranium

"Bring the uranium"

55. [n-sepāre $\left.{ }^{74} \quad l \varepsilon z \quad a t \tilde{o}^{75}\right]$

1SG-seperate.IMPF DEF.PL atom

"I'll seperate the atoms"
56. [la
kado $^{76} \mathrm{n}$-həț-o
fI-1-pāki $\left.{ }^{77}\right]$

DEF.MASC present 1SG-put.IMPF-3MSG.OBJ in-DEF-package

"I put the present in the package"

${ }^{1}$ noire
${ }^{5}$ monumentale
${ }^{9}$ anesthésie
${ }^{13}$ le Nice
${ }^{17}$ les combines
${ }^{21}$ kamikaze
${ }^{25}$ sauvage
${ }^{29}$ cric
${ }^{33}$ la poste
${ }^{37}$ cent milles salariés
${ }^{41}$ brancher
${ }^{45}$ jet set
${ }^{49}$ charger
${ }^{53}$ blanc
${ }^{57}$ trois cents millions
${ }^{61}$ même
${ }^{65}$ les poumons
${ }^{69}$ au fond
${ }_{73}$ l'uranium
${ }^{77}$ paquet

${ }^{2}$ des cobayes
${ }^{6}$ mental
${ }^{10}$ cimetière
${ }^{14}$ la mafia Russe
${ }^{18}$ riche
${ }^{22}$ cobaye
${ }^{26}$ voyage
${ }^{30}$ des millions
${ }^{34}$ la banque
${ }^{38}$ l'affaire
${ }^{42}$ mon argent
${ }^{46}$ ma patrie
${ }^{50}$ les batteries
${ }^{54}$ pour le moment
${ }^{58}$ sécrétaire
${ }^{62}$ les problèmes
${ }^{66}$ diazepam
${ }_{70}$ le corps
${ }^{74}$ séparer

${ }^{3}$ laboratoire

${ }^{7}$ la civière

${ }^{11}$ domaine

${ }^{15}$ la cocaïne

${ }^{19}$ jamais

${ }^{23}$ la société

${ }^{27}$ des affaires

${ }^{31}$ action

${ }^{35}$ francs

${ }_{39}$ archimilliardaire

${ }^{43}$ et des banques

${ }^{47}$ des parties

${ }^{51}$ l'affaire

${ }^{55}$ pourtant

${ }^{59}$ détournement

${ }^{63}$ la fin

${ }^{67}$ sauter

${ }^{71}$ expérience

${ }^{75}$ les atomes
${ }^{4}$ faute

${ }^{8}$ sérum

12 même

${ }^{16}$ le cannabis

${ }^{20}$ racaille

${ }^{24}$ publicité

${ }^{28}$ mes projets

${ }^{32}$ des complices

${ }^{36}$ la paie

${ }^{40}$ braquage à l'italienne

${ }^{44}$ la

${ }^{48}$ le temps

${ }^{52}$ relation

${ }^{56}$ à peu près

${ }^{60}$ l'europe

${ }^{64}$ sinon

${ }^{68}$ les boulons

${ }^{72}$ la dose

${ }^{76}$ le cadeau

\section{GA3DA FEBLED}

1. [frãs ${ }^{1}$ t-qədm-u]

France 3F-develop.IMPF-PL

"France is developed"

2. [?̄̄ajə-sufri-w ${ }^{2}$ ]

PROG-3PL 3M-suffer.IMPF-PL

"They are suffering" 
3. [le jon ${ }^{3}$ tą-həm yīr la $m \bar{o} d^{4}$ li rāj t-həm-u] DEF.PL youth GEN-3PL only DEF.FEM fashion REL opinion 3F-matter.IMPF-PL "Their young people are only interested in fashion"

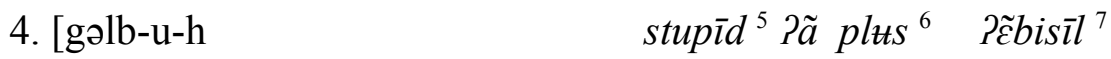

transform.PERF-3PL-3MSG.OBJ stupid in addition fool

"They made him stupid as well as a fool"

b stār akadimi ${ }^{8} \mathrm{~W} \quad$ lowana $^{9}$ fi la pisīn $\left.{ }^{10}\right]$

by Star Academy and Loana in DEF.FEM pool

"By Star Academy and Loana in the pool"

5. [ћkəm-hum stres $\left.{ }^{11}\right]$

control.PERF-3PL stress

"Stress controls them"

6. [wəl-āw smān b la gres $^{12}$ ]

become.PERF-3PL fat by DEF-FEM grease

"They became fat from the grease"

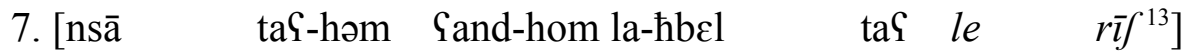
woman.PL GEN-3PL to-3PL DEF-insanity GEN DEF.PL rich

"Their women have the insanity of the rich"

8. [ma-j-wold- $\overline{\mathrm{u}}-\int \quad l e \quad$ bebe $\left.{ }^{14}\right]$

NEG-3M-birth.IMPF-PL-NEG DEF.PL baby

"They don't have babies"

9. [jə-rabī-w le kanī ${ }^{15}$ ]

3M-raise.IMPF-PL DEF.FEM poodle

"They raise poodles"

10. [brõzā ${ }^{16}$ kul-o $\quad \mathrm{kd}$ bb b le rajo ${ }^{17}$ Pultra vijole ${ }^{18}$ ]

tan all-3MSG lie by DEF.PL ray ultra violet

"Their tans are all fake from the ultra violet rays"

11. [ma-j-okl-ū- $\int$ le pat $\left.^{19}\right]$

NEG-3M-eat.IMPF-PL-NEG DEF.PL pasta

"They don't eat pasta" 
12. [?i-xāf-u me-r-rizim ${ }^{20}$ ]

3M-scare.IMPF-PL from-DEF-dieting

"they are scared of dieting"

13. [twaћəर-t l-alziri ${ }^{21}$ bI-l-burāk $\quad$ w tazīn] miss.PERF-1SG DEF-Algeria by-DEF-bourak and tagine "I miss Algeria with its Bourak and Tagine"

14. [hijə l-imāz ${ }^{22}$ mYa wāld-i-k fūg t-tablə] 3FSG.PRO DEF-image with parent-PL-2SG.POS above DEF-table "It's the image of your parents at the table"

15. [mem ${ }^{23}$ ləkān fi-1-orōp ${ }^{24}$ le ter $\tilde{\varepsilon}^{25}$ kul-hum gaz $\left.\tilde{O}^{26}\right]$ even if in-DEF-Europe DEF.PL field all-3PL grass "Even if in Europe the playgrounds are all grass"

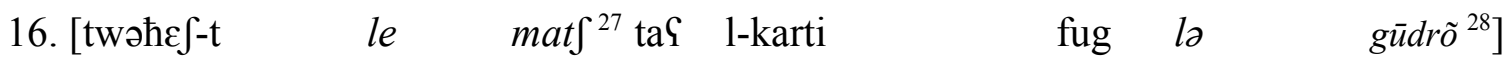
miss.PERF-1SG DEF.PL match GEN DEF-neighborhood above DEF.MASC asphalt "I miss the games of the neighborhood on the asphalt"

17. [l-arbītr ${ }^{29}$ dīmə hajāl]

DEF-referee always unjust

"The referee is always unjust"

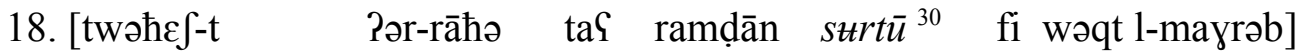
miss.PERF-2SG DEF-smell GEN Ramadan especially in time DEF-sunset "I miss the smell of Ramadan especially during sunset"

${ }^{1}$ frança

${ }^{5}$ stupide

${ }^{9}$ Loana

${ }^{13}$ les riches

${ }^{17}$ les rayons

${ }^{21}$ l'Algérie

${ }^{25}$ les terrains

${ }^{29}$ l'arbitre
${ }^{2}$ souffrir

${ }^{6}$ en plus

${ }^{10}$ la piscine

${ }^{14}$ les bébés

${ }^{18}$ ultra violet

${ }^{22}$ l'image

${ }^{26}$ gazon

${ }^{30}$ surtout
${ }^{3}$ les jeunes

${ }^{7}$ imbécile

${ }^{11}$ stress

${ }^{15}$ les caniches

${ }^{19}$ les pâtes

${ }^{23}$ même

${ }^{27}$ les matchs
${ }^{4}$ la mode

${ }^{8}$ Star Académie

12 la graisse

${ }^{16}$ bronzage

${ }^{20}$ régime

${ }^{24}$ l'Europe

${ }^{28}$ le goudron

\section{KLAB}

1. [Saml-u le $\left.\operatorname{deg} \bar{a}^{1}\right]$ made.PERF-3PL DEF.PL damage

"They made the damage" 
2. [Q-Stị-ni $\left.\quad p \bar{i} j a^{2}\right]$

IMP-give-1SG.OBJ $P A$

"Give me a $P A$ *"

*PA = pistolet automatique ('automatic pistol')

3. [gdah jornalisst ${ }^{3}$ həz-u-h]

how.many journalist lift.PERF-3PL-3MSG.OBJ

"How many journalists lifted it"

4. [le jon ${ }^{4}$ Pi-sizi-w-əl-hum ${ }^{5} \quad$ fi-d-duxān mə le kāba ${ }^{6}$ ]

DEF.PL youth 3F-seize.IMPF-PL-to-3PL.OBJ in-DEF-smoke from DEF.PL bag

"They seized cigarettes from the bags of the youth"

5. [1ə-mSalīm gaYdə dīr fe-l-komers ${ }^{7}$ taht t-tabla] DEF-important.people continue.PARTIC do.PERF in-DEF-business under DEF-table "Important people keep doing under the table business"

6. [?ā-m gaYr-o d-dinjə $\quad$ b le $\quad k \tilde{t n c r^{8}}$ ]

PROG-3PL bottomed.out.PERF-3PL DEF-world by DEF.PL containers

"They bottomed the world out in shipping containers"

7. [ $\mathrm{faSb}$ gəlb-u-h $\left.k \tilde{o}^{9}\right]$

people transform.PERF-3PL-3MSG.OBJ idiot

"They turned the people into idiots"

8. [jə-Yabi-w bi-h Pəl-kõp bãkcr ${ }^{10}$ ]

3M-fill.IMPF-PL by-3MSG DEF-account banking

"They fill the bank account"

9. $\left[l-\tilde{a} k \varepsilon t^{11}\right.$ mə-kān- $]$

DEF-investigation NEG-exist.PERF-NEG

"There's no investigation"

10. $\left[l-u \sin -\bar{a} t^{12}\right.$ gaSdə t-hal li-jūm wahdə wrə lo-xra $]$ DEF-factory-PL continue.PARTIC 3F-open.IMPF DEF-day one behind DEF-other

"The factories are opening today one after another"

11. [1-māklə la pijes ${ }^{13} \mathrm{~W}$ dwə kul tqətৎ-wə]

DEF-food DEF.FEM piece and medicine all run.out.PERF-3PL

"The food, the peice and all the medicine has run out"

12. [dār-o 1-fajdo de IIjõ $^{14} \mathrm{~W}$ de miljār ${ }^{15}$ ] do.PERF-3PL DEF-profit INDEF.PL million and INDEF.PL billion

"They make millions and billions in profit" 


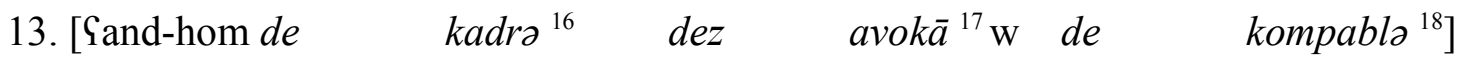
to-3PL INDEF.PL organization INDEF.PL lawyer and INDEF.PL accountant "They have organizations, lawyers and accountants"

14. [ma-jə-3arf-ū- $\int \quad l a \quad$ priso ${ }^{19}{ }^{19}$ NEG-3M-know.IMPF-PL-NEG DEF.FEM prison "They don't know prison"

15. [la-yramə dimə t-zi-hum zIrO ${ }^{20}$ vIrgut $^{21}$ zIrO $^{20}$ zIrO $^{20}$ pur sa $\tilde{a}^{22}$ ] DEF-penalty always $3 \mathrm{~F}-$-come.IMPF-3PL.OBJ zero comma zero zero per hundred "The penality always comes to them at 0,00 percent"

16. [t-Yādi fi-3-3urnāl $\left.{ }^{23}\right]$

3F-pass.IMPF in-DEF-newspaper

"It passes in the newspaper"

17. [māt-u kūl bi-s-sīda ${ }^{24}$ wə-1-kõser ${ }^{25}$ ]

die.PERF-3PL all by-DEF-AIDS and-DEF cancer

"They all died of AIDS and cancer"

${ }^{1}$ les dégâts

${ }^{5}$ saisir

${ }^{9}$ cons

${ }^{13}$ la pièce

${ }^{17}$ des avocats

${ }^{21}$ virgule

${ }^{25}$ cancer

${ }^{2}$ PA
${ }^{6}$ les cabas
${ }^{10}$ compte bancaire
${ }^{14}$ des millions
${ }^{18}$ des comptables
${ }^{22}$ pour cent

${ }^{3}$ journaliste

${ }^{7}$ commerce

${ }^{11}$ l'enquête

${ }^{15}$ des milliards

${ }^{19}$ la prison

${ }^{23}$ journal
${ }^{4}$ les jeunes

${ }^{8}$ les conteneurs

${ }^{12}$ l'usine

${ }^{16}$ des cadres

${ }^{20}$ zéro

${ }^{24}$ SIDA

\section{BLED MIKI}

1. [kuləS $\left.f^{1}{ }^{1}\right]$ everything fake

"Everything is fake"

2. [kuləs fa-ha m-fabrīki $\left.{ }^{2}\right]$ everything in-3FSG PARTIC-fabricate

"Everything in it is fabricated" 
3. [tI-lgə dinjə $\mathrm{mi} \int$ normā $\left.^{3}{ }^{3}\right]$

2SG-find.IMPF world NEG normal

"You find the world is not normal"

4. [saby-o le trotwār $\left.{ }^{4}\right]$

paint.PERF-3PL DEF.PL curb

"They painted the curbs"

5. [wagf-īn msākən me-l-ajropor ${ }^{5}$ hatən la vij ${ }^{6}$ ] poor-PL live.PARTIC from-DEF-airport until DEF.FEM city

"The poor are living from the airport to the city"

6. [?ā-w $\quad s y r^{7}$ rāh ?i-kūli]

PROG-3MSG surely FUT 3M-drown.IMPF

"He is surely going to drown"

7. [nahi-w-1-o la $\quad \operatorname{paj}^{8} \mathrm{~W}$ la $\quad$ prīm ${ }^{9}$ taS $3 \bar{u} r n i^{10}$ ] take.PERF-3PL-to-3SG.OBJ DEF.FEM pay and DEF.FEM bonus GEN day

"They took from him his salary and the bonus of the day"

8. [3āb-u drāri șyār taS 1-primer ${ }^{11} \quad$ wə-s-sckõdcr ${ }^{12}$ ] bring.PERF-3PL children small.PL GEN DEF-elementary and-DEF-secondary

"They brought the little kids from elementary school and middle school"

9. [fI-3-3amiGa le profusur ${ }^{13} \overline{\mathrm{a}}-\mathrm{m} \quad \mathrm{daS}-\mathrm{u} \quad$ b- $\left.\int-\int \partial r\right]$ in-DEF-university DEF.PL professor PROG-3PL lose.PERF-3PL by-DEF-evil "In the university, the professors are starving (lit. 'lost to evil')"

10. [la $\quad$ paj $^{14}$ taS-hum fət $]$

DEF.FEM pay GEN-3PL pass.PERF

"Their pay passed"

11. [j-dīr le $k \bar{u} r^{15} l e^{16}$ drāri șyār tạ sanə sads-ə]

3M-do.IMPF DEF.PL lesson DEF.PL children small.PL GEN year sixth-FEM

"He made the lessons for the young kids of the sixth grade"

12. [lez ctudjä ${ }^{17}$ hatīn-o]

DEF student demean.PARTIC.PL-3MSG.OBJ

"The students are demeaning him"

13. [jə-zdm-o la parlemã ${ }^{19}$ ]

3M-invade.IMPF-PL DEF parlement

"They invade the Parliament" 
14. [ja-ћki-w $\quad$ Sa le miljõ ${ }^{20}$ fi la premjer rejunjo ${ }^{21}$ ] 3M-speak.IMPF-PL about DEF.PL million in DEF.FEM first meeting "They talk about the millions in the first meeting"

15. [n-hab surtu $^{22}$ swarəd-kom $]$

1SG-love.IMPF especially money-2PL.POS

"I love your money especially"

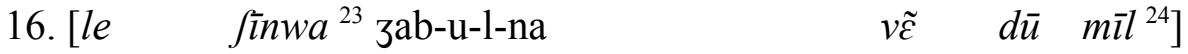

DEF.PL Chinese bring.PERF-3PL-to-1PL.OBJ twenty two thousand

"They brought us 22,000 Chinese"

17. [ћnayə fi- $\left.\int-\int o m \bar{a} 3^{25}\right]$

1PL.PRO in-DEF-unemployment

"We are jobless"

18. [daৎwə Pa-j fi-d-dãzi ${ }^{26}$ ] situation PROG-3F in-DEF-danger

"The meeting is in danger"

19. [ [ $\mathrm{a} a \mathrm{cb}$ Pa-w rāh je-plõzi $\left.{ }^{27}\right]$ people PROG-3MSG FUT 3M-sink.IMPF

"the people are going to sink"

20. [1-mYaləm jə-vojāzi $\left.{ }^{28}\right]$

DEF-boss 3M-travel.IMPF

"The boss travels"

21. [t-mõzi $\left.{ }^{29}\right]$

3F-eat.IMPF

"She eats"

22. [fi bled mīki kūləf fa-ha $v r \varepsilon j^{30}$ ]

in country weak everything in-3FSG real

"In a weak country, everything in it is real"

23. [3āb-u-1-na lham hmār fre ${ }^{31}$ ]

bring.PERF-3PL-to-1PL.OBJ meat donkey fresh

"They brought us fresh donkey meat"

24. [xsārə 3ā māləh Jwijə sali ${ }^{32}$ ]

unfortunately come.PERF salted.PARTIC little salty

"Unfortunately it came salted, a little salty" 
25. [bejn kejn mat $^{33}$ ] clearly exist.PERF match "Clearly there is a match"

26. [1-mūhim fi le gradã ${ }^{34}$ ged $\varepsilon h$ getl-u] DEF-important in DEF.PL bleacher how.many kill.PERF-3PL "The important thing in the bleachers is how many they killed"

27. [wejn-o l-arbitra ${ }^{35}$ ] where-3MSG DEF-referee "Where's the referee?"

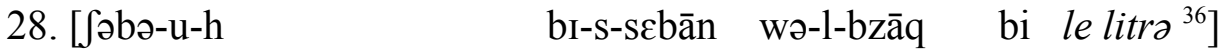
fill.PERF-3PL-3MSG.OBJ by insult.PL and-DEF-spit by DEF.PL liter "They filled him with insults and liters of spit"

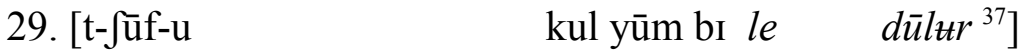
2SG-see.IMPF-3MSG.OBJ all day by DEF.PL pain

"You see him every day in pain"

30. [la ma-ḍab-ū-h- $\int \quad$ le spektatur ${ }^{38}$ ] NEG NEG-hit.PERF-3PL-3MSG.OBJ-NEG DEF.PL spectator "If the spectators didn't beat him"

31. [jo-ḍrb-ū-h le $\left.\quad 3 u w z r^{39}\right]$

3M-hit.IMPF-PL-3MSG.OBJ DEF.PL player

"The players beat him"

32. [xațak fi lez urzãs ${ }^{40} \quad$ Pəd-daxlə $\quad$ rā-j $\quad$ hbāl] because in DEF.PL emergency.room DEF-entrance PROG-3FSG crazy "Because in the emergency room, the entrance is crazy"

33. [jə-ћōṭ-o le vidur ${ }^{41}$ ]

3M-put.IMPF-PL DEF.PL gaurd

"They put security guards"

34. [ sirom $^{42}$ mə-kān-f] serum NEG-exist.PERF-NEG

"There's no serum" 


$\begin{array}{llll}{ }^{1} \text { faux } & { }^{2} \text { fabriquer } & { }^{3} \text { normal } & { }^{4} \text { les trottoirs } \\ { }^{5} \text { l'aeroport } & { }^{6} \text { la ville } & { }^{7} \text { sur } & { }^{8} \text { la paie } \\ { }^{9} \text { la prime } & { }^{10} \text { journée } & { }^{11} \text { primaire } & { }^{12} \text { secondaire } \\ { }^{13} \text { les professeurs } & { }^{14} \text { la paie } & { }^{15} \text { les cours } & { }^{16} \text { les } \\ { }^{17} \text { les étudiants } & { }^{18} \text { le parlement } & { }^{19} \text { les millions } & { }^{20} \text { la première réunion } \\ { }^{21} \text { Surtout } & { }^{22} \text { les chinois } & { }^{23} \text { vingt-deux mille } & { }^{24} \text { chômage } \\ { }^{25} \text { danger } & { }^{26} \text { plonger } & { }^{27} \text { voyager } & { }^{28} \text { manger } \\ { }^{29} \text { vrai } & { }^{30} \text { frais } & { }^{31} \text { salé } & { }^{32} \text { match } \\ { }^{33} \text { les gradins } & { }^{34} \text { l'arbitre } & { }^{35} \text { les litres } & { }^{36} \text { les douleurs } \\ { }^{37} \text { les } \text { spectateurs } & { }^{38} \text { les joueurs } & { }^{39} \text { les urgences } & { }^{40} \text { les videurs } \\ { }^{41} \text { Sérum } & & & \end{array}$

\section{HIGH TECHNOLOGY}

\section{1. [lāzəm t-ləsq-o kimə l-pat ${ }^{1}$ ]} must 2SG-stick.IMPF-3MSG.OBJ like DEF patch "You have to stick it on like a patch"

2. [Q-Yāmorle pārol ${ }^{2}$ ki-1-mikanizm ${ }^{3} \quad$ tå swat $\left.^{4}\right]$ IMP-fill DEF.PL word like-DEF-mechanism GEN Swatch "Fill the lyrics like the mechanism of a Swatch"

3. [le text ${ }^{5}$ Q-Paktb-hom bi le cristo $^{6}$ taS la kwarts $\left.^{7}\right]$ DEF.PL text IMP-write-3PL.OBJ by DEF.PL crystal GEN DEF.MASC quartz "Write the texts with the crystals of the quartz"

4. [Q-kasər le frāz ${ }^{8}$ fi le frekõs ${ }^{9}$ Pen megahertəz ${ }^{10}$ ] IMP-break DEF.PL sentence in DEF.PL frequency in megahertz "Break the sentences in the megahertz frequencies"

5. [Q-Paћkəm le suze ${ }^{11}$ kif le vertabar $\left.{ }^{12}\right]$ IMP-control DEF.MASC subject like DEF.PL vertebrae "Control the topic like vertabraes"

6. [hatān te-bni 1-maSnə ki la-hrām $\quad$ li $\quad$ fi-l-ijīpt ${ }^{13}$ ] until 2SG-build.IMPF DEF-meaning like DEF-pyramid.PL REL in-DEF-Egypt "Until you build the meaning like the pyramids in Egypt"

7. [Q-3īb la sijõs ${ }^{14}$ ta؟ Indijāno zōns $\left.{ }^{15}\right]$

IMP-bring DEF.FEM science GEN $\underline{\text { Indiana Jones }}$

"Bring the science of Indiana Jones" 


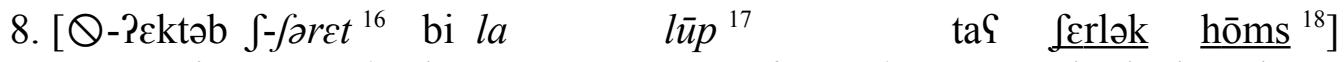
IMP-write DEF-plan by DEF.FEM magnifying.glass GEN Sherlock Holmes "Write the plan with the magnifying glass of Sherlock Holmes"

9. [xətak le $\quad k \tilde{o}^{19}$ tạ $\quad$ ?ems fi-1-ārd] because DEF.PL idiot GEN yesterday in-DEF-earth

"Because the idiots of yesterday are in the earth"

10. [nə-plāni ${ }^{20}$ fūg-hum kimə jūri gagarīn]

1SG-plane.IMPF above-3PL like Youri Gagarin

"I am soaring above them like Yuri Gagarin"

11. [fi $r \bar{a} p^{21} \mathrm{~m}$-bloki-jīn $\left.{ }^{22}\right]$

in rap PARTIC-block-PL

"They are blocked in rap"

12. $\left[p \varepsilon r d \mathrm{a}-\mathrm{w}^{23} \quad 1-k \bar{d} d \quad \operatorname{pin}^{24}\right]$

lost.PERF-3PL DEF-code pin

"They lost the password"

13. $\left[\operatorname{malgr\varepsilon }^{25}\right.$ Pa-m m-dōpj-in $\left.{ }^{26}\right]$

despite PROG-3PL PARTIC-dope-PL

"Despite them doping"

14. [mə-zāl-u $\quad$ kəm $^{27}$ de gaminn $^{28}$ ]

NEG-still-3MSG like INDEF.PL girl

"They are still like girls"

15. [Cand-i tro ${ }^{29} d$-adrenalīn ${ }^{30}$ ]

to-1SG much INDEF.SG-adrenaline

"I have a lot of adrenaline"

16. [1-m̧āni fi le rìm ${ }^{31}$ ]

DEF-meaning.PL in DEF.PL rhyme

"The meanings are in the rhymes"

17. [had $\varepsilon j ə \int \varepsilon$ Sr $\quad \bar{o} t \quad \operatorname{gam}^{32}$ ]

DEM poetry high class

"This is high quality poetry"

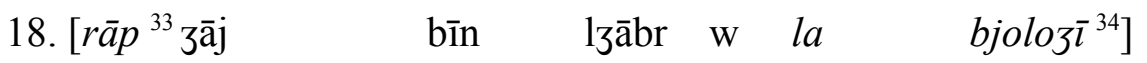

rap come.PARTIC between algebra and DEF.FEM biology

"Rap comes between algebra and biology" 
19. $\left[Q\right.$-plõzi ${ }^{35}$ s-sõ ${ }^{36} \quad$ fi la $\quad$ sas ${ }^{37}$ taS la $\quad$ sijõs ${ }^{38}$ hādi $]$ IMP-dip DEF-sound in DEF.FEM sauce GEN DEF.FEM science DEM "Dip the sound into the sauce of this science"

20. [tõ $\quad s t \bar{l}{ }^{39} \mathrm{ji-wIli} \quad$ Pãsikklopad $\left.\bar{\imath}^{40}\right]$

2SG.POS style 3M-become.IMPF encyclopedia

"Your style will become an encyclopedia"

21. $\left[r \bar{a} p^{41}\right.$ Pa-w $\quad$ sров $^{42}$ fì-h la kõdisjõ fizzì $\left.k^{43}\right]$

rap PROG-3MSG sport in-3MSG DEF.FEM condition physical

"Rap is a sport with physical conditioning"

22. [s-stīlu ${ }^{44}$ jə-wili sūpl ${ }^{45}$ zaSmə l-kīk $\quad$ boksīn $\left.^{46}\right]$

DEF-pen 3M-become.IMPF flexible like DEF-kick boxing

"The pen becomes flexible like kick boxing"

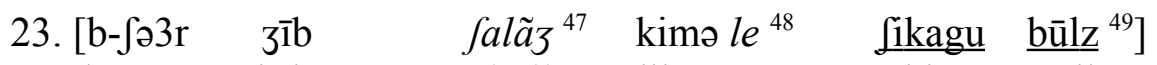

by-poetry bring.PERF challenge like DEF.PL Chicago Bulls

"With poetry comes challenges like the Chicago Bulls"

24. [t-wili Por-rwa ${ }^{50}$ fi la kūrs ${ }^{51}$ ]

2-become.IMPF DEF-king in DEF.FEM race

"You become the king in the race"

25. $\left[Q-d \bar{u} b l i^{52}\right.$ 1-həmās $]$

IMP-double DEF-enthusiasm

"Double the enthusiasm"

26. [jə-staGrf-o bi-k Pən-nās kimə $\underline{\operatorname{star}}^{53}{ }^{3 \varepsilon s i}$ ?ōwens $\left.{ }^{54}\right]$

3M-acknowledge-PL by-2SG DEF-people like star Jesse Owens

"People will ackowledge you like the star Jesse Owens"

27. $\left[Q-3 \bar{i} b \quad r \varepsilon k o b^{55}\right]$

IMP-bring record

"Bring a record"

28. [la $m \varepsilon d a j{ }^{56}$ hījə dibka]

DEF.FEM medal 3FSG.PRO Debka

"The medal is the Debka"

29. [Q-țalå la $\quad b \bar{a} r^{57} 1$-füg]

IMP-raise DEF.FEM bar DEF-above

"Raise the bar high" 
30. [mədam la kūrs ${ }^{58}$ bȲìd-ə]

since DEF.FEM race far-FEM

"Since the race is far"

31. [Q-țala؟ par $\varepsilon t \bar{a}{ }^{59}$ ]

IMP-raise by step

"Go up by steps"

32. [rītam ${ }^{60}$ taS rāp ${ }^{61}$ Pa-w kimo rītom kardijāk ${ }^{62}$ ]

rythme GEN rap PROG-3MSG like ryhtme cardiac

"The rhythm of the rap is like the cardiac rhythm"

33. [Q-bdə-ha ?ã ptīt fūle ${ }^{63}$ ]

IMP-start-3FSG.OBJ in small stride

"Start it with small strides"

34. [Q-rāmi $\left.{ }^{64}\right]$

IMP-row

"Row"

35. $\left[Q-r \bar{u} l i{ }^{65}\right]$

IMP-roll

"Roll"

36. $\left[\right.$ rāp ${ }^{66} \mathrm{mI}$-o $\quad r \overline{a l i}{ }^{67}$ wlə kat sõ $\quad$ metr ${ }^{68}$ rulej $\left.{ }^{69}\right]$

rap NEG-3MSG rally or four hundred meter relay

"Rap is not a rally nor 400 meters relay"

37. [jə-giț-ō-ni le pavar ${ }^{70}$ ]

3M-cut.IMPF-PL-1SG.OBJ DEF.PL poor

"The poor will cut me"

38. [n-əsta9məl fi-hum kam de lijevro ${ }^{71}$ ]

1SG-use.IMPF in-3PL like INDEF.PL rabbit

"I'm using them as rabbits"

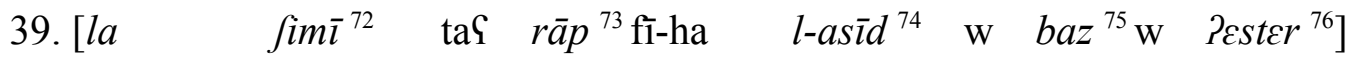

DEF.FEM chemistry GEN rap in-3FSG DEF-acid and base and ester

"The chemistry of rap contains acid, base and ester"

40. [Q-əsmaS mõ $\left.\operatorname{text}^{77}\right]$

IMP-listen 1SG.POS text

"Listen to my text" 
41. [n-ћot-o fi miksus ${ }^{78}$ ]

1SG-put-3MSG.OBJ in blender

"I put it in a blender"

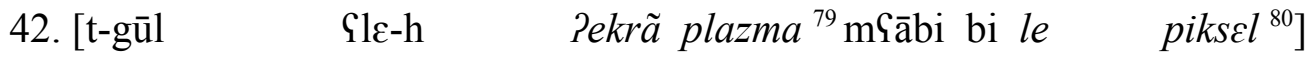
2SG-say.IMPF about-3MSG screen plasma full.PL by DEF.PL pixel

"You think it's like a plasma screen full of pixels"

43. $\left[\right.$ la calūl ${ }^{81} \mathrm{ki} \quad \mathrm{t}$-dīr $\quad$ mitos $\left.^{82}\right]$

DEF.FEM cell when 3F-do.IMPF mitosis

"When the cell does mitosis"

44. [Yand-o dez $\tilde{\varepsilon} z \bar{\imath}{ }^{83}$ ] to-3MSG INDEF.PL enzyme

"It has some enzymes"

45. [?i-zlgzagi-w ${ }^{84}$ kif la $l a \bar{\imath}$ ? ${ }^{85}{ }^{85}$ ]

3M-zigzag.IMPF-PL like DEF.MASC B $\quad M$

"It zigzags like a $B M W$ "

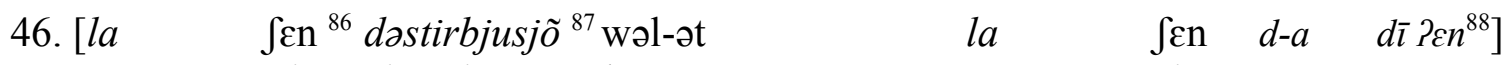

DEF.FEM chain distribution become.PERF-3FSG DEF.FEM chain GEN-A D N

"The valve train became the DNA chain"

47. [kuləs Pan asmōz $\left.{ }^{89}\right]$

everything in osmosis

"Everything is in osmosis"

48. $\left[r \overline{a p p}{ }^{90} z^{\mathrm{a} j} \mathrm{~m} \quad\right.$ mə-1-kosmōs $\left.{ }^{91}\right]$

rap come.PARTIC from-DEF-cosmos

"Rap comes from the cosmos"

49. [Yand-u kõsijõs ${ }^{92}$ ]

to-3MSG consciousness

"It has a consciousness"

50. [ kalsjam $^{93}$ Pi-jī fi nas $\quad$ l-os $^{94}$ ]

calcium 3M-come.IMPF in 1SG.POS DEF-bone

"Calcium comes from our bones"

51. [mif-ni kobaj ${ }^{95}$ ]

NEG-1SG guinea.pig

"I'm not a guinea pig" 
52. [fug Por-ring ${ }^{96}$ taS rāp ${ }^{97}$ Q-Yajet-1-i mohamed klaj $^{98}$ ] above DEF-ring GEN rap IMP-call-to-1SG.OBJ Mohammed Clay "Above the rap ring call me Mohammed Clay"

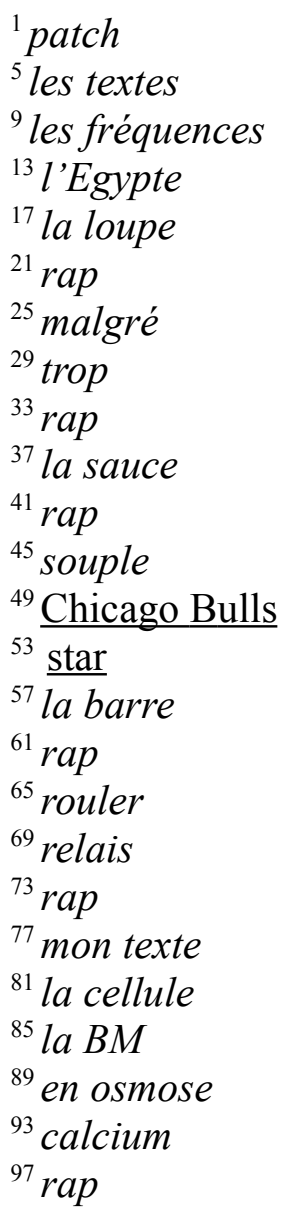

${ }^{2}$ les paroles
${ }^{6}$ les cristaux
${ }^{10}$ en mégahertz
${ }^{14}$ la science
${ }^{18}$ Sherlok Holmes
${ }^{22}$ bloquer
${ }^{26}$ doper
${ }^{30}$ d'adrénaline
${ }^{34}$ la biologie
${ }^{38}$ la science
${ }^{42}$ sport
${ }^{46}$ kick boxing
${ }^{50}$ roi
${ }^{54}$ Jesse Owens
${ }^{58}$ la course
${ }^{62}$ rythme cardiaque
${ }^{66}$ rap
${ }^{70}$ les pauvres
${ }^{74}$ l'acide
${ }^{78}$ mixeur
${ }^{82}$ mitose
${ }^{86}$ la chaîne
${ }^{90}$ rap
${ }_{94}^{94}$ nos l'os
${ }_{98}$ Clay

${ }^{3}$ mécanisme

${ }^{7}$ le quartz

${ }^{11}$ le sujet

${ }^{15}$ Indiana Jones

${ }^{19}$ les cons

${ }^{23}$ perdre

${ }^{27}$ comme

${ }^{31}$ les rimes

${ }^{35}$ plonger

${ }^{39}$ ton style

${ }^{43}$ la condition physique

${ }^{47}$ challenges

${ }^{51}$ la course

${ }^{55}$ record

${ }^{59}$ par étape

${ }^{63}$ en petites foulées

${ }^{67}$ rallye

${ }^{71}$ comme des lièvres

${ }^{75}$ base

${ }^{79}$ écran plasma

${ }^{83}$ des enzymes

${ }^{87}$ distribution

${ }^{91}$ cosmos

${ }^{95}$ cobaye
${ }^{4}$ swatch

${ }^{8}$ les phrases

${ }^{12}$ les vertèbres

${ }^{16}$ charrette

${ }^{20}$ planer

${ }^{24}$ code pin

${ }^{28}$ des gamines

${ }^{32}$ haute gamme

${ }^{36}$ son

${ }^{40}$ encyclopédie

${ }^{44}$ stylo

${ }^{48}$ les

${ }^{52}$ doubler

${ }^{56}$ la médaille

${ }^{60}$ rythme

${ }^{64}$ ramer

68400 mètres

${ }^{72}$ la chimie

${ }^{76}$ ester

${ }^{80}$ les pixels

${ }^{84}$ zigzaguer

${ }^{88}$ la chaîne d'ADN

${ }^{92}$ conscience

${ }^{96}$ ring

\section{ANI JAY}

1. [kuləs mə-blok $\left.\mathrm{i}^{1}{ }^{1}\right]$ everything PARTIC-block

"Everything is blocked"

2. [kuləS mə-stōki $\left.{ }^{2}\right]$ everything PARTIC-stock "Everything is saved" 
3. [Q-Paqrə bij $\left.\tilde{\varepsilon}^{3}\right]$

IMP-read well

"Ask and read well"

4. [wə⿱ sār fi-j-jurnā $\left.{ }^{4}\right]$

what happen.PERF in-DEF-newspaper

"What happened in the newspaper"

5. [hāsi meşūd fa-ha gedeh me-d-dosjer nwar ${ }^{5}$ ] Hassi Messaoud in-3FSG how.many from-DEF-file black

"How many black folders are in Hassi Messaoud"

6. [3āme ${ }^{6}$ jo-xroz fi le foto $\left.{ }^{7}\right]$

never 3SG-exit in DEF.FEM photo

"It never comes out in photos"

7. [kimə gāl 1-masīhi me-1 la pusijer ${ }^{8} 1 \varepsilon-1 \quad$ la $\quad$ pusijer ${ }^{8}$ ] like say.PERF DEF-Christian from-DEF DEF.FEM dust to-DEF DEF.FEM dust

"Like the christians say from the dust to dust"

8. [?a-m Jajx-īn wro 1-buro $\left.{ }^{9}\right]$

PROG-3PL old-PL behind DEF-desk

"They are the old ones behind the desk"

9. $\left[\right.$ rasə ${ }^{10}$ dijə ji-ћeb-o]

race DEM 3M-like.IMPF-PL

"This race likes to"

10. $\left[\right.$ la $\quad$ sir $\tilde{\varepsilon}^{11}$ t- - ajet $]$

DEF.FEM siren 3F-ring.out

"The siren rings out"

11. [ma-t-ৎawəl- $\int \quad$ Sa la tele ${ }^{-12}$ ]

NEG-2SG-rely.IMPF-NEG about DEF.FEM television

"Don't rely on the television"

12. [l-afer ${ }^{13} \quad$ tgəlb-ət $\quad$ Cli-hom]

DEF-situation change-3FSG about-3PL

"The situation changed on them"

$\begin{array}{llll}{ }^{1} \text { bloquer } & { }^{2} \text { stocker } & { }^{3} \text { bien } & { }^{4} \text { journal } \\ { }^{5} \text { dossier noir } & { }^{6} \text { jamais } & { }^{7} \text { les photos } & { }^{8} \text { la poussière } \\ { }^{9} \text { bureau } & { }^{10} \text { race } & { }^{11} \text { la sirène } & { }^{12} \text { la télé } \\ { }^{13} \text { l'affaire } & & \end{array}$

